\title{
Structure Separation Experiments Phase 1 Preliminary Test Plan
}

Alexander Maranghides

Shonali Nazare

Eric Link

Kuldeep Prasad

Matthew Hoehler

Matthew Bundy

Steven Hawks

Frank Bigelow

William (Ruddy) Mell

Anthony Bova

Derek McNamara

Tom Milac

Daniel Gorham

Faraz Hedayati

Bob Raymer

Frank Frievalt

William Walton

This publication is available free of charge from: https://doi.org/10.6028/NIST.TN.2161

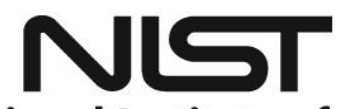




\section{NIST Technical Note 2161}

\section{Structure Separation Experiments Phase 1 Preliminary Test Plan}

Alexander Maranghides, Shonali Nazare, Eric Link, Kuldeep Prasad, Matthew Hoehler, Matthew Bundy

Fire Research Division, Engineering Laboratory

National Institute of Standards and Technology

Steven Hawks, Frank Bigelow Office of the State Fire Marshal California Department of Forestry and Fire Protection

William (Ruddy) Mell, Anthony Bova, Derek McNamara, Tom Milac United States Forest Service

Daniel Gorham, Faraz Hedayati Insurance Institute for Businesses and Home Safety

Bob Raymer

California Building Industry Association

Frank Frievalt

Mammoth Lakes Fire Protection District

William Walton

University of Maryland

This publication is available free of charge from:

https://doi.org/10.6028/NIST.TN.2161

May 2021

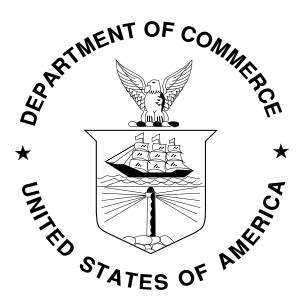

U.S. Department of Commerce Gina M. Raimondo, Secretary

National Institute of Standards and Technology James K. Olthoff, Performing the Non-Exclusive Functions and Duties of the Under Secretary of Commerce for Standards and Technology \& Director, National Institute of Standards and Technology 
Certain commercial entities, equipment, or materials may be identified in this document in order to describe an experimental procedure or concept adequately. Such identification is not intended to imply recommendation or endorsement by the National Institute of Standards and Technology, nor is it intended to imply that the entities, materials, or equipment are necessarily the best available for the purpose.

The policy of NIST is to use the International System of Units in all publications. In this document, however, units are presented in the system prevalent in the relevant discipline, although in some cases more than one system of units may be presented.

National Institute of Standards and Technology Technical Note 2161

Natl. Inst. Stand. Technol. Tech. Note 2161, 88 pages (May 2021)

CODEN: NTNOEF

This publication is available free of charge from:

https://doi.org/10.6028/NIST.TN.2161 


\begin{abstract}
The primary objective of this project is to assess structure-to-structure fire spread for structures located in the Wildland-Urban Interface (WUI). Full-scale fire experiments will be conducted in which various types of structures (sources of fire) will be used to generate typical radiative and convective heat exposures on target structures (residential dwellings). The spacing between the source and target structures will be varied to identify safe structure separation distance (SSD). Most experiments will be conducted with construction materials currently listed in State of California building codes and using code compliant structural assemblies. A limited number of experiments will be conducted with enhanced, ignitionresistant, materials that may not currently be listed by the State of California.

The project is divided into three phases. Phase 1 will test sheds as fire sources, Phase 2 will test "in-law" buildings (small accommodation structures built close to primary residential structure) and Phase 3 will test single-family homes. Source terms from $1.39 \mathrm{~m}^{2}$ to $24.8 \mathrm{~m}^{2}$ $\left(15 \mathrm{ft}^{2}\right.$ to $\left.267 \mathrm{ft}^{2}\right)$ will be tested in Phase 1. Phase 2 will examine exposures from $40.9 \mathrm{~m}^{2}$ $\left(440 \mathrm{ft}^{2}\right)$ "in-law" buildings, and Phase 3 will characterize exposures from approximately $92.90 \mathrm{~m}^{2}\left(1000 \mathrm{ft}^{2}\right)$ residences. Dimensions of Phase 3 single residences (source term) will be finalized after numerical modeling of the results from Phase 1 and Phase 2. This test plan focuses on Phase 1 research.

Phase 1 aims to quantify the effects of shed sizes, construction types, fuel loading, and separation distance on the ignition of primary structures (residential dwellings). Experiments will be conducted at the National Institute of Standards and Technology (NIST) and the Insurance Institute for Business and Home Safety (IBHS). The NIST experiments will be conducted at the National Fire Research Laboratory (NFRL), and the IBHS experiments will be conducted just outside of the wind loading test cell. The opening of the test cell $(13.7 \mathrm{~m}$ $(45 \mathrm{ft})$ wide) will dictate the largest source structure that can be evaluated at IBHS.
\end{abstract}

\title{
Key words
}

Structure separation distance; fire; sheds; wind; heat release rate; mass loss; modeling; wildland-urban interface. 


\section{Table of Contents}

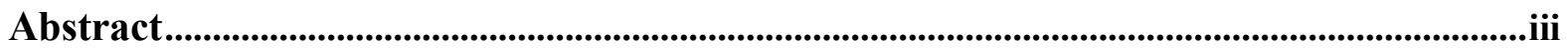

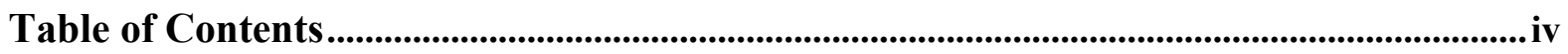

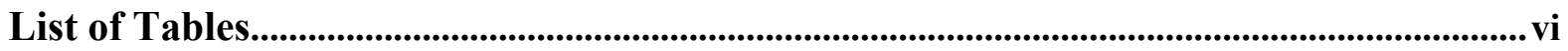

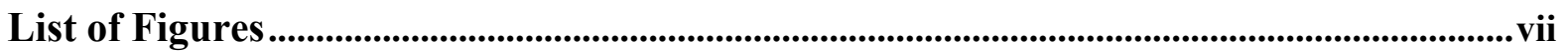

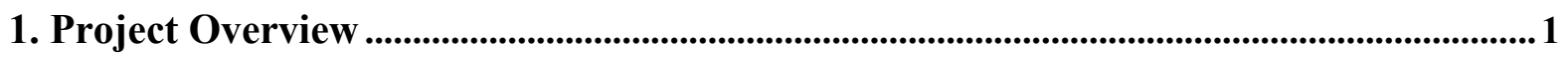

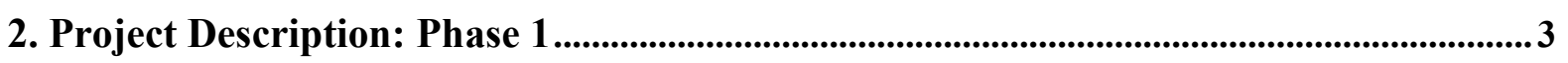

3. Phase 1A: Cold Flow Measurements and Phase 1B Design ..............................................5

3.1. Technical issues.................................................................................................. 5

3.2. Location of experiments ................................................................................... 5

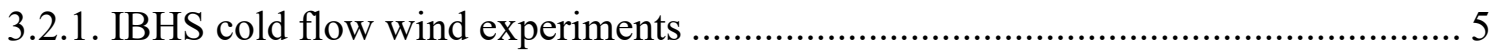

4. Phase 1B: NIST Shed Burn Experiments without Wind ..................................................... 7

4.1. Technical issues........................................................................................... 7

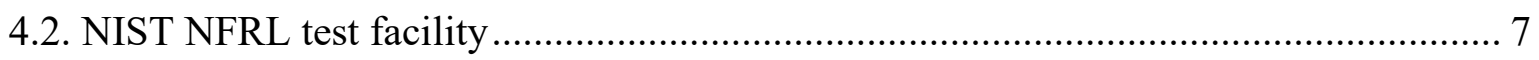

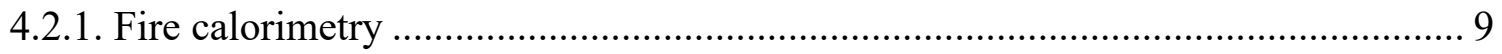

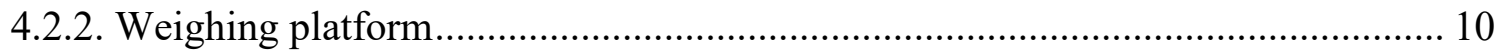

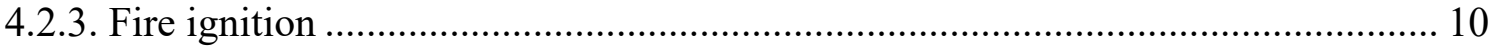

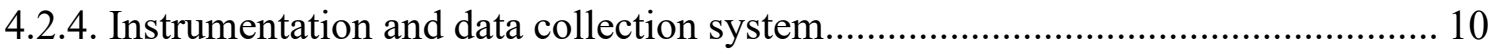

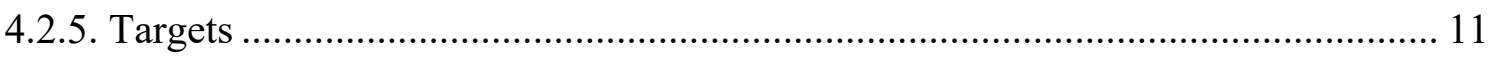

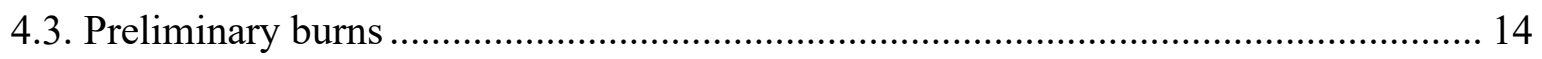

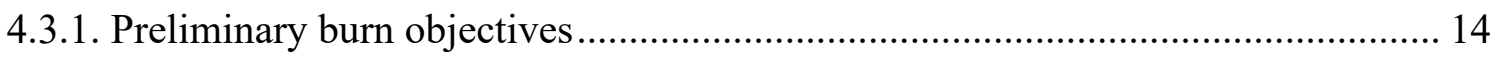

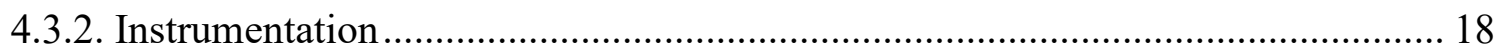

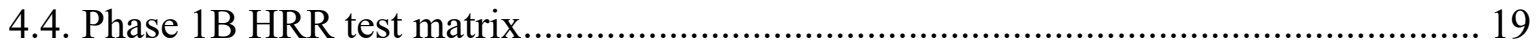

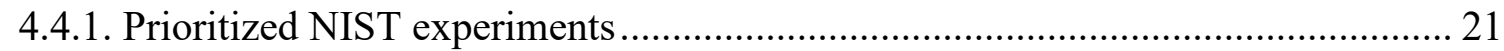

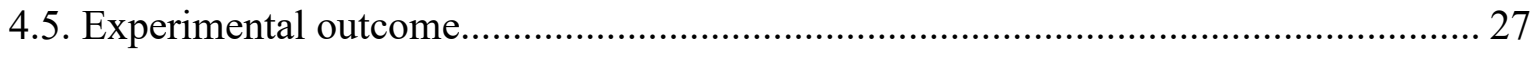

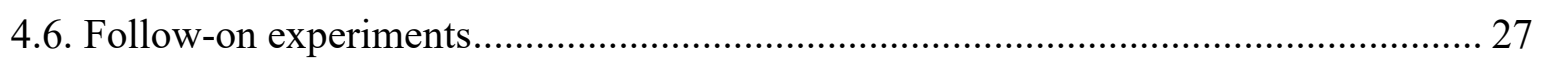

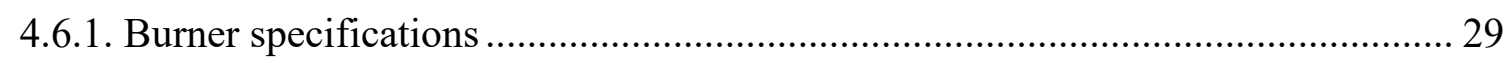

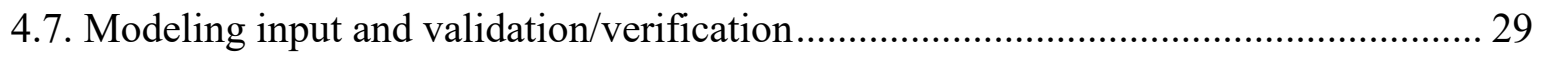

5. Phase 1B: IBHS Shed Burn Experiments (no HRR) .............................................................. 30

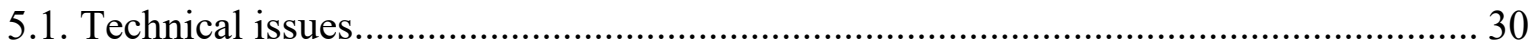

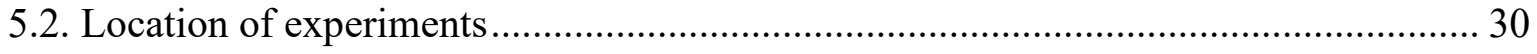

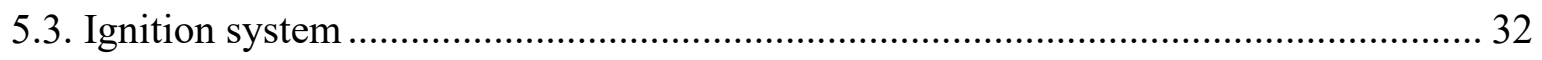

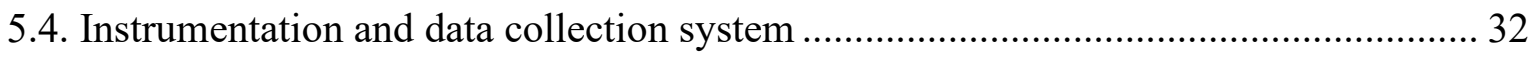

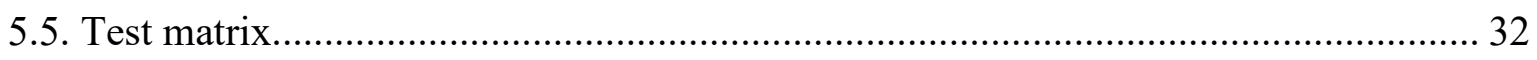

5.5.1. Shed burn experiments to determine mass loss (no wind) ............................... 33

5.5.2. Shed burn experiments to measure structure separation distance (with wind)..... 34 


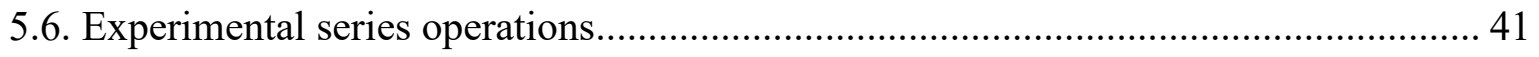

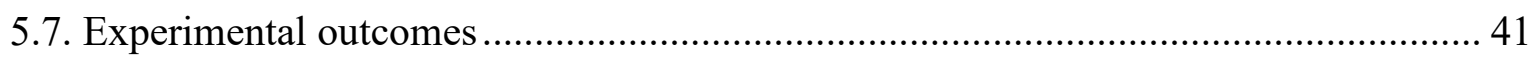

6. Modeling of Experiment Design and Experiments......................................................42

6.1. Model development to estimate safe separation distance ....................................... 42

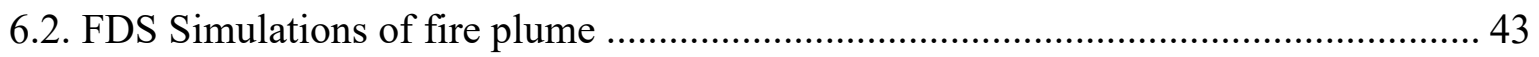

6.3. Different wind orientations and structure layouts ........................................... 46

6.4. Target dimensions including elevation ( single story source) ................................. 49

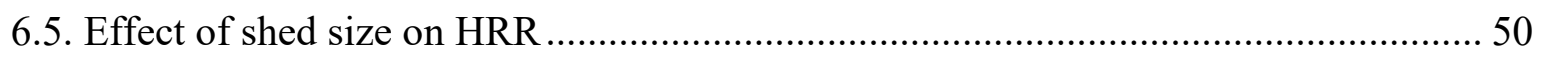

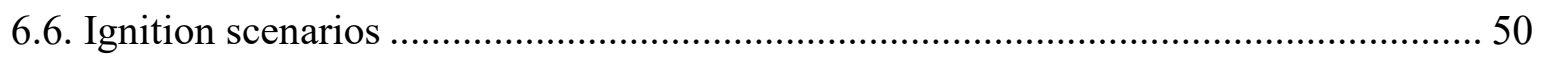

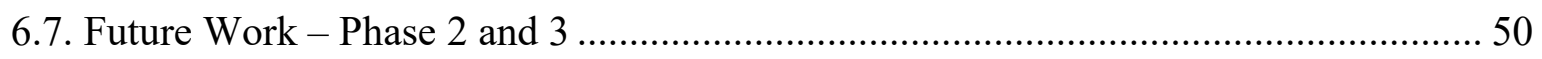

7. CAL FIRE, NIST, IBHS, and USFS Teams Workflow....................................................... 52

8. Data Management ..................................................................................................................................5 53

References..............................................................................................................................................5 54

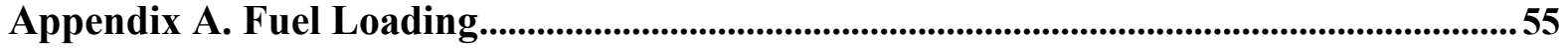

Appendix B. Weighing Platform Design ................................................................................................. 62

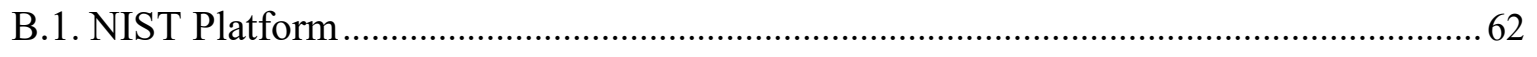

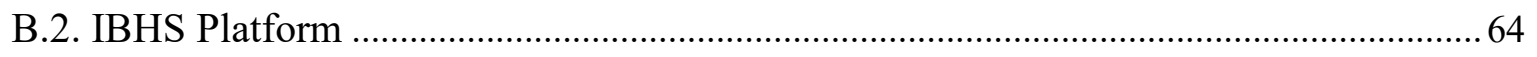

Appendix C. Target Structure Design Specifications........................................................65

Appendix D. IBHS Experiments —SSD and Instrumentation ...........................................68

Appendix E. IBHS Experiments: Vulnerabilities of Structure Corners ............................. 72

Appendix F. Preliminary Data Management and Quality Assurance Project Plan ........ 73

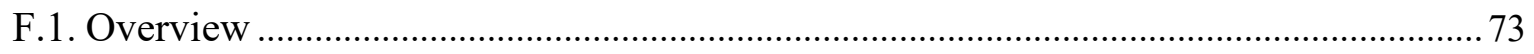

F.2. Structure Separation Experiment data catalog information documentation................. 73

F.3. Structure Separation Experiment file and attribute naming conventions ..................... 75

F.4. Structure Separation Experiment tabular, raster, image, and video data structure

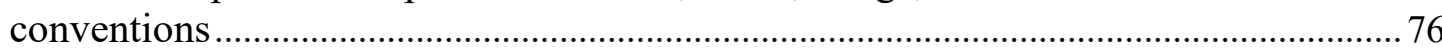

F.5. Structure Separation Experiment Data Flows for Measurement Specialists, Data Collectors, and Data Managers..... 78 


\section{List of Tables}

Table 1: Phase 1A Tasks and Lead Organization(s) ........................................................ 4

Table 2: Phase 1B Tasks and Lead Organization(s). ......................................................... 4

Table 3: IBHS test matrix - Preliminary test matrix based on cold flow data. ..................... 6

Table 4: Test parameters for Phase 1B NIST experiments $(1 \mathrm{ft}=0.0305 \mathrm{~m})$................... 19

Table 5: Experiments to characterize fuel loading for Phase 1B NIST experiments (wood

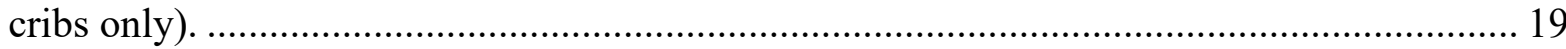

Table 6: Possible test space for Phase 1B NIST shed burn experiments (no wind)............ 20

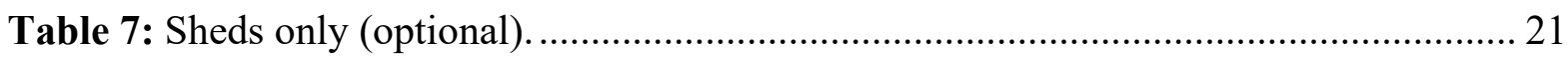

Table 8: Priority sequence for NIST NFRL testing. .................................................... 22

Table 9: Shed specifications for experiments at NIST NFRL $(1 \mathrm{ft}=0.0305 \mathrm{~m}$, $1 \mathrm{lb}=0.453 \mathrm{~kg})$.

Table 10: Phase 1B small secondary structure exposure source (shed) burn experiments at IBHS (without target structure)

Table 11: Phase 1B small secondary structure exposure source (shed) burn experiments at IBHS (with wind).

Table 12: Phase 1B preliminary test matrix, small secondary structure exposure source (shed) burn experiments at IBHS (with wind).

Table 13: Specifications for medium, large and very large sheds to be tested at IBHS test facility $(1 \mathrm{ft}=0.0305 \mathrm{~m}, 1 \mathrm{lb}=0.453 \mathrm{~kg})$.

Table 14. Major modeling tasks and the associated primary technical issues during Phase 1 of the Structure Separation Experiments (SSE).

Table 15. Major modeling tasks and the associated primary technical issues during Phase 2 and 3 of the Structure Separation Experiments (SSE)

Table A-1: Fuel loading specifications for different source structures $(1 \mathrm{ft} .=0.0305 \mathrm{~m}$,

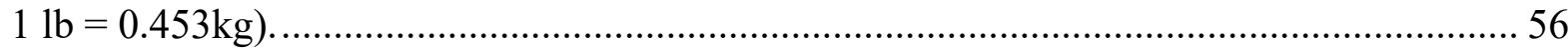

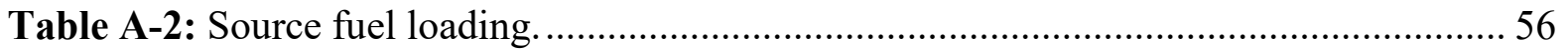

Table A-3: Maximum mass of source structures (mass of shed + mass of cribs) $(1 \mathrm{ft}=$ $0.0305 \mathrm{~m}, 1 \mathrm{lb}=0.453 \mathrm{~kg})$.

Table B-1: Design loads for weighing modules for Phase 1B NIST shed burn experiments; final values provided in SI units.

Table B-2: SSD range and platform size range for IBHS shed burn experiments $(1 \mathrm{ft}=0.305 \mathrm{~m})$.

Table D-1: Target orientation for various shed sizes for IBHS shed burn experiments.

Table D-2: Test specifications and instrumentation for IBHS shed burn experiments with and without wind $(1 \mathrm{ft}=0.0305 \mathrm{~m})$. 70

Table D-3: Test specifications and instrumentation for IBHS shed burn experiments with wind and $\operatorname{SSD}(1 \mathrm{ft}=0.0305 \mathrm{~m})$. 


\section{List of Figures}

Figure 1: Photos of very small and small sheds in common locations against the primary structure and near additional vulnerabilities such as windows and combustible fencing. Photo Credits: NIST.

Figure 2: Shed placement in (A) One property, (B) Two properties (figure not to scale)..... 2 Figure 3: NIST NFRL test facility. Imagery: Google, Landsat/Copernicus. Overlays: NIST. 8 Figure 4: Schematic of the NIST NFRL test facility, locations of platform, and target

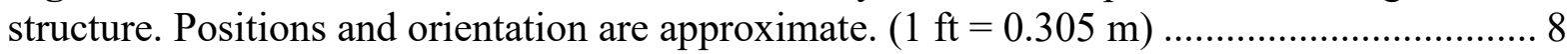

Figure 5: Target and source placement under the $10 \mathrm{MW}$ exhaust hood (figure not to scale). 9 Figure 6: Schematic elevation drawing of the weighing platform at one corner (figure not to scale).

Figure 7: Target structure and source (closet or very small shed) configuration (figure not to

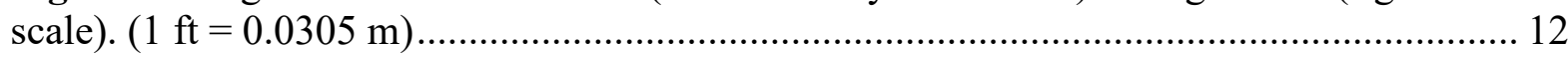

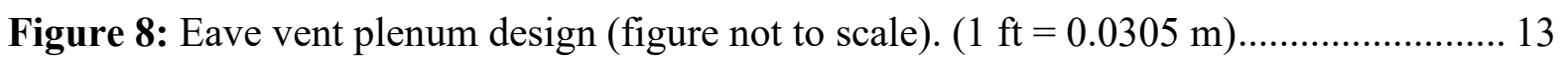

Figure 9: Plan and a cross-sectional view of $1.5 \mathrm{~m} \times 1.0 \mathrm{~m}$ gas burner pan and distribution manifold (figure not to scale).

Figure 10: Non-combustible instrumented target structure for preliminary burns (figure not to scale). $(1 \mathrm{ft} .=0.0305 \mathrm{~m})$..

Figure 11: Front and top view of the instrumented target wall used in preliminary burns

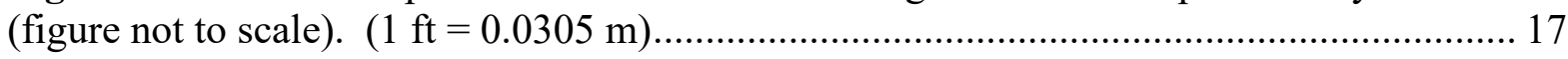

Figure 12. Top view of experimental set-up under the hood......................................... 18

Figure 13: Conditional flowchart for developing NFRL test matrix................................ 23

Figure 14: Target structure with roof and eaves and burner location [4]. ......................... 28

Figure 15: Gas diffusion burner dimensions [4] ....................................................... 29

Figure 16: Aerial view of IBHS test facility (April 2018). Imagery: Google, Landsat/ Copernicus. Overlays: NIST.

Figure 17: Aerial view of test facility (April 2018) and locations of target and source buildings. Positions and orientations are approximate. Imagery: Google, Landsat/Copernicus. Overlays: NIST.

Figure 18: Aerial view of IBHS test facility (April 2018), source building at $0^{\circ}$ and target building at $45^{\circ}$. Positions and orientations approximate. Imagery: Google, Landsat/ Copernicus. Overlays: NIST.

Figure 19: Load cells and mass loss platform for IBHS shed burn experiments without wind (figure not to scale). 34

Figure 20: Conditional flowchart for IBHS test matrix. 36

Figure 21: Instantaneous temperature iso-surface plots for heat release rates of $(1,2,4,8$, and 16) MW from $1 \mathrm{~m} \times 1 \mathrm{~m}$ propane burner (with no ambient wind)..... 44

Figure 22: Numerical simulation of a $16 \mathrm{MW}$ burner placed in an ambient wind of $4 \mathrm{~m} / \mathrm{s}$. Results show the deflection of the fire plume. 
Figure 23: Radiative heat flux $\left(\mathrm{kW} / \mathrm{m}^{2}\right)$ for a gauge pointing towards burner (representing walls) and gauge pointing downwards (representing eaves). .

Figure 24: Different wind orientations and structure layouts (figure not to scale).............. 46

Figure 25: Different source and target structure layouts with respect to wind orientations. . 47

Figure 26: Orientation of source openings (figure not to scale)..................................... 48

Figure 27: Target structure dimensions - including elevation (figure not to scale)............ 49

Figure B-1: Scale drawing of proposed modular truss framing for weighing platform during Phase 1B NIST shed burn experiments (source: www.milossystems.com).

Figure B-2: Proposed weighing module with fixture for weighing platform for Phase 1B experiments at NIST: (a) schematic for weighing module with the fixture (not to scale; PTFE = Polytetrafluoroethylene); (b) proposed weighing module (source: www.hbm.com)......... 64

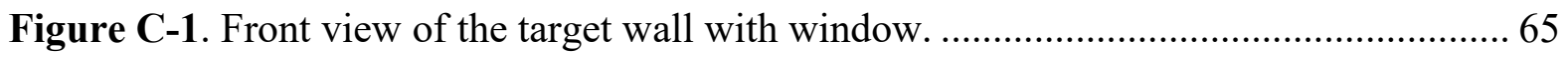

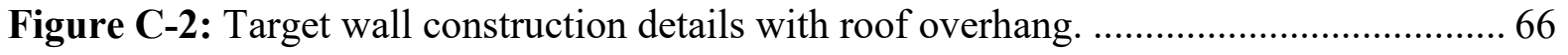

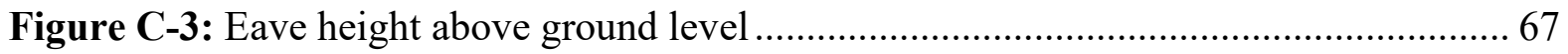

Figure D-1: IBHS shed orientation: Medium shed at $45^{\circ}$ and target at $45^{\circ}$ (figure not to scale).

Figure D-2: IBHS shed orientation: Very large shed at $0^{\circ}$ and target at $45^{\circ}$ (figure not to scale). 68

Figure D-3: IBHS shed orientation: Very large shed at $0^{\circ}$ and target at $90^{\circ}$ (figure not to scale). 


\section{Project Overview}

This project is a collaboration among the California Department of Forestry and Fire Protection (CAL FIRE), the California Building Industry Association (CBIA), the United States Forest Service (USFS), the Insurance Institute for Business and Home Safety (IBHS), and the National Institute of Standards and Technology (NIST).

The primary objective of this project is to assess structure-to-structure fire spread for structures located in the Wildland-Urban Interface (WUI). Full-scale fire experiments will be conducted in which various types of structures (sources of fire) will be used to generate typical radiative and convective heat exposures on target structures on target structures (residential dwellings). The spacing between the source and target structures will be varied to identify safe structure separation distance (SSD). SSD is defined as the shortest distance between the source and target structures, i.e., if eaves are used, then the measurement will be from the eaves not the wall. Most experiments will be conducted with construction materials currently listed in State of California building codes and using code compliant structural assemblies. A limited number of experiments will be conducted with enhanced (ignition resistant) materials that may not currently be listed by the State of California Building Code.

The project is divided into three phases. Phase 1 will test sheds as fire sources, Phase 2 will test "in-law" buildings (small accommodation structures built close to primary residential structure) and Phase 3 will test single-family homes. Source terms from $1.4 \mathrm{~m}^{2}$ to $24.8 \mathrm{~m}^{2}$ $\left(15 \mathrm{ft}^{2}\right.$ to $\left.267 \mathrm{ft}^{2}\right)$ will be tested in Phase 1 . Phase 2 will examine exposures from a $40.9 \mathrm{~m}^{2}$ $\left(440 \mathrm{ft}^{2}\right)$ "in-law" buildings, and Phase 3 will characterize exposures from approximately $92.9 \mathrm{~m}^{2}\left(1000 \mathrm{ft}^{2}\right)$ residences. Dimensions of Phase 3 single residences (source term) will be finalized after numerical modeling of the results from Phase 1 and Phase 2. This preliminary test plan focuses on Phase 1 research and is subject to modifications as additional knowledge is gained and technical issues encountered during the execution of the project.

Closets (C), Very Small (VS), and Small (S) sheds are frequently designed with a single pitch roof (without a ridge) and are typically placed next to residential structures. In cases of two-story buildings, these sheds may be located under second-floor windows, as seen in Figure 1. The primary exposures considered for fire hazard during shed installation is a residential structure (if one is present). Secondary structures, other combustible features (e.g., fence), or combustible vegetation are also considered. For sheds and accessory structures in excess of $11 \mathrm{~m}^{2}\left(120 \mathrm{ft}^{2}\right)$ floor area, placement requirements exist with respect to residential structure(s) on the same lot (Figure 2A) through Chapter 7A [1] of the California Building Code (referred to subsequently as Chapter 7A). However, there is potential for an additional fire exposure to a neighboring property as shown by the red arrow in Figure 2B. No placement requirement or guidance is currently provided in these configurations.

Phase 1 aims to quantify the effects of shed sizes, construction types, fuel loading, and separation distance on the ignition of primary structures. Experiments will be conducted at NIST and IBHS. The NIST experiments will be conducted at the National Fire Research Laboratory (NFRL), and the IBHS experiments will be conducted just outside of the wind loading test cell. The opening of the test cell $(13.7 \mathrm{~m}(45 \mathrm{ft})$ wide $)$ will dictate the largest source (shed) structure that can be evaluated at IBHS. 


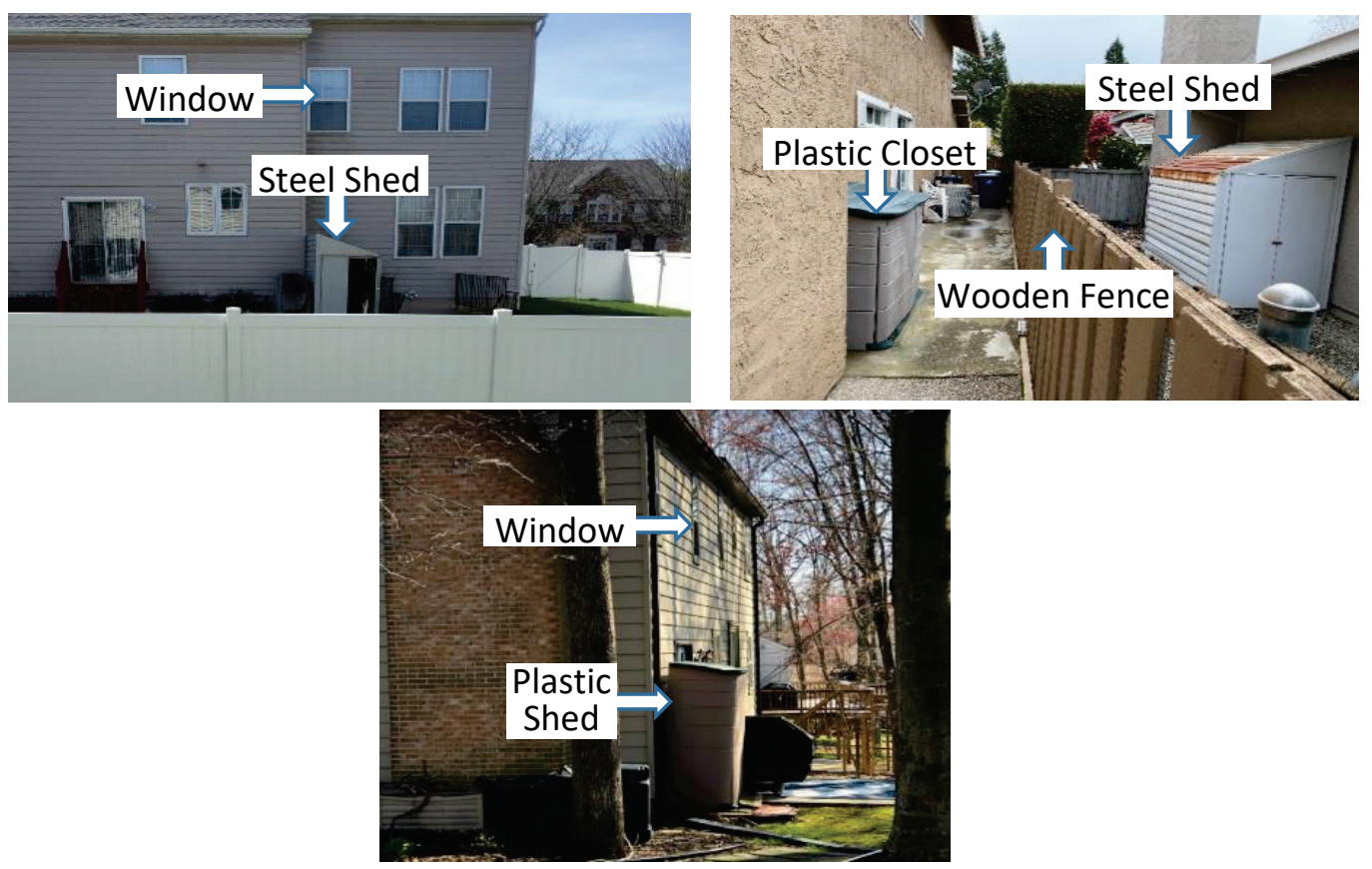

Figure 1: Photos of very small and small sheds in common locations against the primary structure and near additional vulnerabilities such as windows and combustible fencing. Photo Credits: NIST.
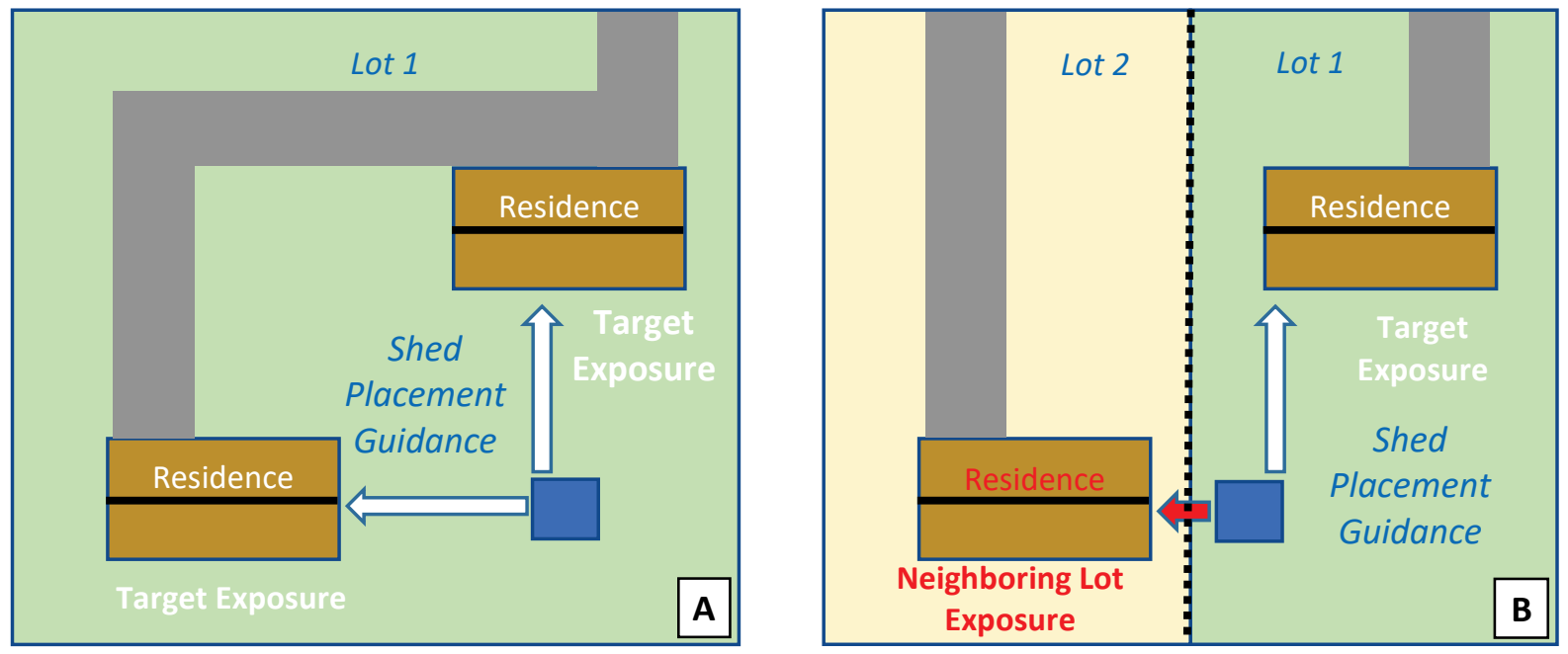

Figure 2: Shed placement in (A) One property, (B) Two properties (figure not to scale). 


\section{Project Description: Phase 1}

The following sections provide an overview of the key activities in Phase 1, which has been divided into two primary stages: Phases $1 \mathrm{~A}$ and $1 \mathrm{~B}$.

\section{Phase 1A: Cold Flow Measurements and Phase 1B Design}

Phase 1A will focus on characterizing the wind field outside the wind loading test cell at IBHS, modeling that wind field, and determining the dimensions of the target structure. Flow measurements and modeling during this phase will also provide guidance for the placement and size limitations of the source term. During this phase of the work the target design configuration will be finalized, and the materials will be selected. NIST will determine the material properties for the selected materials to be used for modeling of the experiments conducted in Phase 1B. Modeling will be used to investigate single and multiple ignition scenarios, and this information will be used to design the ignition procedures used in Phase 1B. Table 1 contains the primary tasks for Phase 1A and the lead organization for each task.

\section{Phase 1B: Shed Burn Experiments}

Phase 1B will focus on exposing the target structure to heating (thermal radiation and convection) from a burning source (shed). A wall and roof assembly with a window will represent a single-story target structure. Various shed sizes, construction types, fuel loading, and spacing between the shed and target structure will be investigated. Shed burn experiments are divided into two parts:

1. NIST shed burn experiments without wind, and

2. IBHS shed burn experiments with and without wind.

Experiments conducted at NIST will quantify heat release rate (HRR) and mass loss rate for different shed sizes, shed constructions, and fuel loadings. This information will be used to model the burning behavior of the sheds and select the sheds that will be burned in the wind field at IBHS. A non-combustible, instrumented target structure will be selected and used for limited preliminary experiments to obtain heat flux measurements. The material properties of the non-combustible, instrumented target structure will be determined at NIST.

Shed burn experiments outside the test cell at IBHS will be performed with and without wind. Experiments will be conducted with a non-combustible instrumented target to obtain heat flux measurements. The instrumented roof-wall assembly will represent a 1.5-story target structure for experiments conducted at IBHS. Various separation distances will be evaluated. Table 2 contains the primary tasks for Phase 1B and the lead organization for each task. 
Table 1: Phase 1A Tasks and Lead Organization(s).

\begin{tabular}{|l|l|}
\hline Organization & Task \\
\hline IBHS & Mapping outside wind field \\
\hline IBHS & Mapping wind flow field between shed and target \\
\hline NIST, CAL FIRE, CBIA & Designing of target structure and selection of sheds \\
\hline NIST & Determining material properties \\
\hline USFS & Modeling of cold flow experiments \\
\hline USFS & Modeling of ignition scenarios \\
\hline
\end{tabular}

Table 2: Phase 1B Tasks and Lead Organization(s).

\begin{tabular}{|l|l|}
\hline Organization & Task \\
\hline IBHS & Determining cold flow wind data (outdoor experiments) \\
\hline IBHS & $\begin{array}{l}\text { IBHS sheds with wind and heat flux target (outdoor } \\
\text { experiments) - provide technical guidance on the design of a } \\
\text { removable piece of the target structure }\end{array}$ \\
\hline NIST, CAL FIRE, CBIA & $\begin{array}{l}\text { Selection of hardened materials and construction system } \\
\text { compliant with Chapter 7A; Construction of targets }\end{array}$ \\
\hline NIST & Material properties of non-CA listed materials \\
\hline NIST & $\begin{array}{l}\text { Heat release rate, mass loss, and flux measurements of sheds } \\
\text { (no wind, indoor experiments) }\end{array}$ \\
\hline IBHS & $\begin{array}{l}\text { Burn experiments: sheds with wind and CA building } \\
\text { assembly in target building (outdoor experiments) }\end{array}$ \\
\hline USFS & Modeling of shed burn experiments \\
\hline NIST, IBHS, USFS, CBIA & Report 1: Shed separation distances from primary residences \\
\hline NIST, IBHS, USFS & $\begin{array}{l}\text { Data Management: adherence to the data management } \\
\text { standards and procedures developed for the project is the } \\
\text { responsibility of all parties involved with the experiments }\end{array}$ \\
\hline
\end{tabular}




\section{Phase 1A: Cold Flow Measurements and Phase 1B Design}

The primary objectives of Phase 1A are as follows:

a. Map wind flow outside the IBHS test cell and determine the size, orientation, and placement of the source and target structures.

b. Develop and test model prediction capabilities.

c. Use experiments and modeling to design Phase 1B.

\subsection{Technical issues}

The following items have been identified as technical issues that will need to be addressed during the activities of Phase 1.

a. Determining the number and placement of wind sensors during cold flow measurements.

b. Positioning the source and target structures relative to wind flow (i.e., moving the target structure downwind when increasing the spacing).

c. Identifying the grid resolution for modeling of cold flow experiments.

d. Developing the modeling and prediction methodology.

e. Determining the construction types for source and targets for Phase 1B, Phase 2, and Phase 3.

f. Identifying instrumentation requirements for Phase 1B, Phase 2, and Phase 3.

\subsection{Location of experiments}

Cold flow experiments will be conducted at the IBHS facility in Richburg, South Carolina.

\subsubsection{IBHS cold flow wind experiments}

Wind flow experiments will be conducted to characterize flow outside the test cell and provide information to determine the placement of the source (sheds for Phase 1) and target structures. Shed specifications are provided in Section 4. The IBHS Phase 1A test matrix can be found in Table 3. The test matrix may be modified, in consultation with CAL FIRE, based on experimental results. 
Table 3: IBHS test matrix - Preliminary test matrix based on cold flow data.

\begin{tabular}{|c|l|l|}
\hline Test ID & Wind and structure particulars & \multicolumn{1}{|c|}{ Technical issue } \\
\hline 1A-CF1 & Cold flow-no shed-low wind & $\begin{array}{l}\text { Determining the extent of usable test } \\
\text { volume (length, width and height) }\end{array}$ \\
\hline 1A-CF2 & Cold flow-no shed-high wind & $\begin{array}{l}\text { Locating the target and source buildings } \\
\text { to be determined after CF1 and CF2 }\end{array}$ \\
\hline 1A-CF3 & $\begin{array}{l}\text { Cold flow-standard target placed at } \\
0^{\circ} \text { (no shed) }\end{array}$ & $\begin{array}{l}\text { Placement of standard target } \\
\text { (determining the movement of target or } \\
\text { source platform) }\end{array}$ \\
\hline 1A-CF4 & $\begin{array}{l}\text { Cold flow-standard target at } 45^{\circ} \\
\text { (no shed) }\end{array}$ & $\begin{array}{l}\text { Determining the dimensions of the } \\
\text { standard target after modeling of CF1 } \\
\text { and CF2 }\end{array}$ \\
\hline 1A-CF5 & $\begin{array}{l}\text { Cold flow- medium (M) shed and } \\
\text { target at } 45^{\circ} \text { (40 ft } \times 25 \mathrm{ft} \times 1.5 \\
\text { stories) on mass loss platform }\end{array}$ & $\begin{array}{l}\text { Identifying cold flow data and } \\
\text { placement and orientation of } \\
\text { medium/large shed }\end{array}$ \\
\hline 1A-CF6 & $\begin{array}{l}\text { Cold flow- medium (M) shed at an } \\
\text { angle to the flow and target at } 45^{\circ}\end{array}$ & $\begin{array}{l}\text { Identifying cold flow data and } \\
\text { placement and orientation of medium } \\
\text { shed }\end{array}$ \\
\hline 1A-CF7 & $\begin{array}{l}\text { Cold flow with large (L) shed and } \\
\text { target at } 45^{\circ}\end{array}$ & $\begin{array}{l}\text { Identifying cold flow data and shed } \\
\text { placement }\end{array}$ \\
\hline 1A-CF8 & $\begin{array}{l}\text { Cold flow-very large (VL) shed } \\
\text { and target at } 45^{\circ}\end{array}$ & $\begin{array}{l}\text { Identifying cold flow data and shed } \\
\text { placement }\end{array}$ \\
\hline 1A-CF9 & $\begin{array}{l}\text { Repeat with target }- \text { particulars } \\
\text { TBD }\end{array}$ & $\begin{array}{l}\text { Identifying cold flow data and shed } \\
\text { placement }\end{array}$ \\
\hline
\end{tabular}




\section{Phase 1B: NIST Shed Burn Experiments without Wind}

The burning behavior of smaller source structures (sheds) will be quantified in terms of heat release rate and mass loss rate. The effects of exposures from source structures on the target structure will also be studied. Sheds with varying sizes and construction materials with various fuel loadings will be tested at the NFRL. In this section, the details of the test facility, instrumentation and data collection system, and rationale for experimental test matrix are provided.

The primary objectives are as follows:

a. Quantify exposures in terms of heat release rate and mass loss rate from sheds with no-wind.

b. Develop and test model prediction capabilities.

c. Use experiments and modeling to design Phases 1B experiments at IBHS. ${ }^{1}$

\subsection{Technical issues}

The following items have been identified as technical issues that will need to be addressed during the Phase 1B NIST shed burn experiments.

a. Designing heat flux (convective and radiative) sensors and weighing platform(s) to capture heat flux measurements and mass loss rate for Phase $1 \mathrm{~B}$ experiments.

b. Determining the number and placement of sensors for shed burn experiments.

c. Identifying construction types for source and targets for Phase 1B at NIST.

d. Determining the fuel loading for Phase 1B tests at NIST (see Appendix A).

e. Identifying instrumentation requirements including visible and infrared (IR) cameras and data acquisition systems for Phase 1B experiments at NIST.

f. Identifying ignition requirements for Phase 1B at NIST (also see Sections 6.6).

g. Developing numerical models and prediction methodology.

h. Determining the grid cell resolution for modeling of fire experiments.

\subsection{NIST NFRL test facility}

The aerial view of the NIST NFRL test facility is shown in . The floor plan of the test facility with the approximate location of the platform and target structure is shown in Figure $4 .{ }^{2}$ The

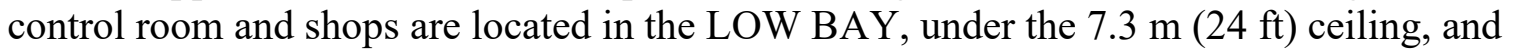

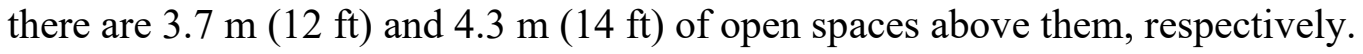

\footnotetext{
${ }^{1}$ The information collected here will also be used to design Phases 2 and Phase 3 experiments.

${ }^{2}$ Structural specifications are provided in US Customary Units as preferred by the construction industry. SI units are used for engineering drawings and wherever necessary.
} 


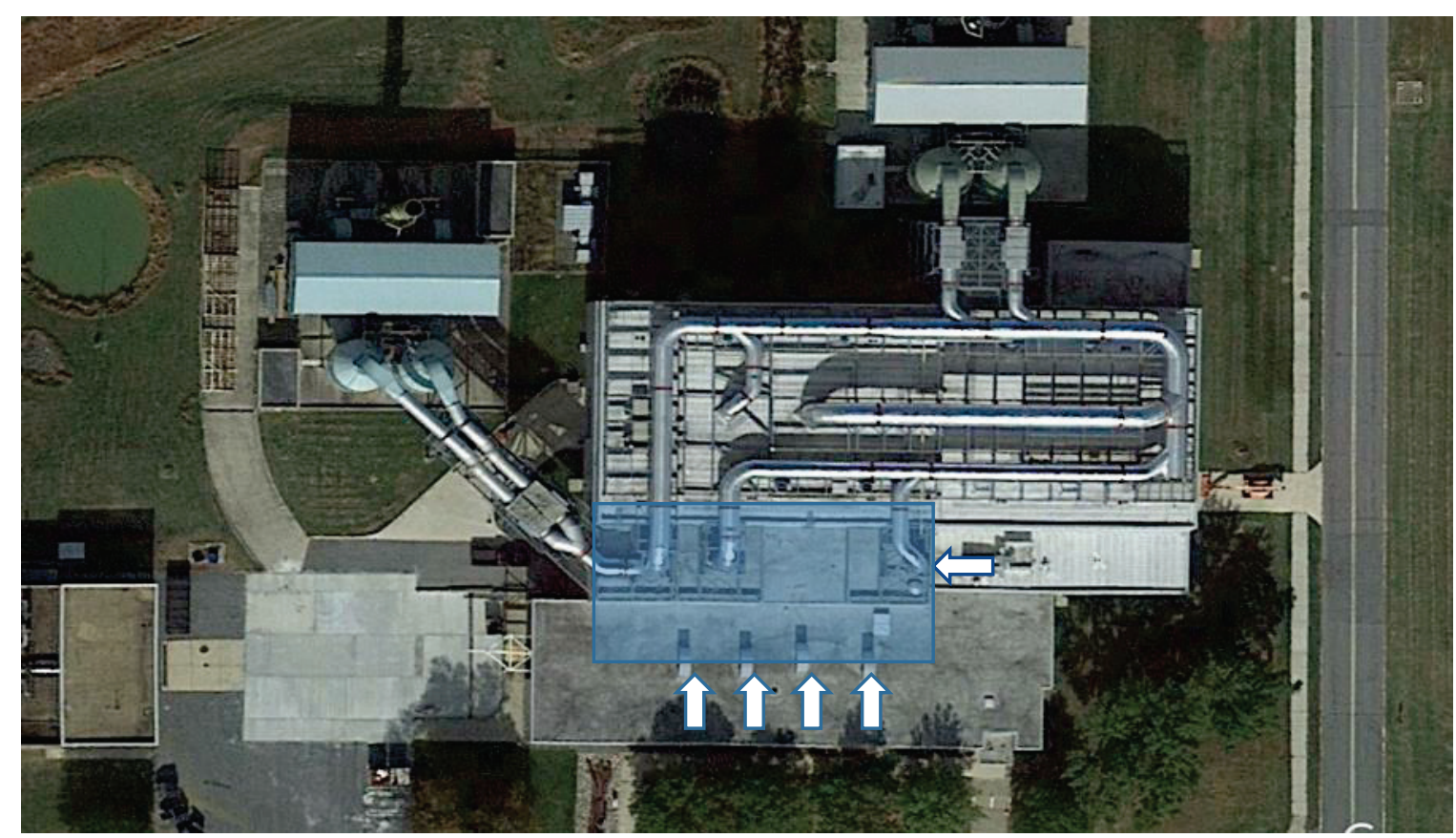

Figure 3: NIST NFRL test facility. Imagery: Google, Landsat/Copernicus. Overlays: NIST.

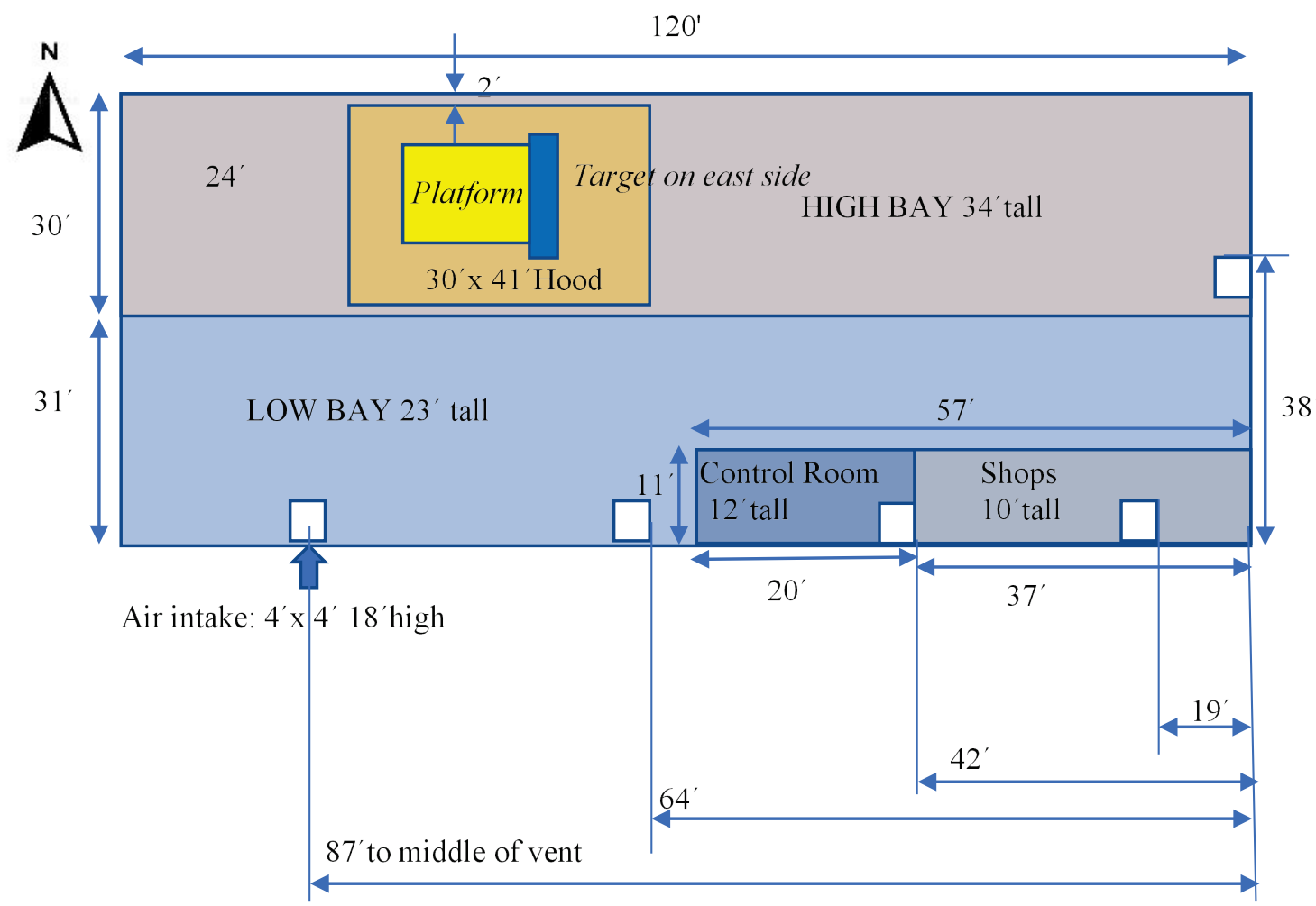

Figure 4: Schematic of the NIST NFRL test facility, locations of platform, and target structure. Positions and orientation are approximate. $(1 \mathrm{ft}=0.305 \mathrm{~m})$ 


\subsubsection{Fire calorimetry}

The calorimetry measurement system at the NFRL allows for measurement of heat release by 1) the principle of oxygen consumption calorimetry and 2) the principle of fuel consumption calorimetry (consumption of natural gas). The NFRL utilizes large canopy exhaust hoods to capture fire effluents for quantification of the heat release as a function of time. The system includes an emissions control system (ECS) to treat smoke particulates and combustion gases to comply with local environmental requirements. The facility has four canopy hoods, each denoted by its maximum fire capacity: $0.5 \mathrm{MW}(3.1 \mathrm{~m} \times 3.2 \mathrm{~m}), 3 \mathrm{MW}(6.1 \mathrm{~m} \times 6.1 \mathrm{~m})$, $10 \mathrm{MW}(8.4 \mathrm{~m} \times 12.4 \mathrm{~m})$, and $20 \mathrm{MW}(13.8 \mathrm{~m} \times 15.4 \mathrm{~m})$. The average expanded uncertainty in the normal operating range for each hood for generic combustible fuel is $7.9 \%, 6.8 \%$, $8.7 \%$, and $9.8 \%$, respectively. This uncertainty is valid for near steady-state fires. Transient events (less than $30 \mathrm{~s}$ ) may have larger uncertainty because of system response time. The range of expanded uncertainty for the natural gas (fuel consumption) verification burners is $1.4 \%$ to $1.8 \%$. Detailed information on the NFRL calorimetry measurement system is provided by Bryant and Bundy [2].

The Phase 1B experiments conducted at NIST will utilize the $10 \mathrm{MW}$ hood. A schematic elevation view of the test setup is shown in Figure 5. Verification (confirmation) of the oxygen consumption calorimeter using fuel consumption calorimetry as a reference will be conducted immediately prior to this test series. Confirmation will be performed within the calorimeter's normal operating range using two fire sizes up to $8 \mathrm{MW}$.

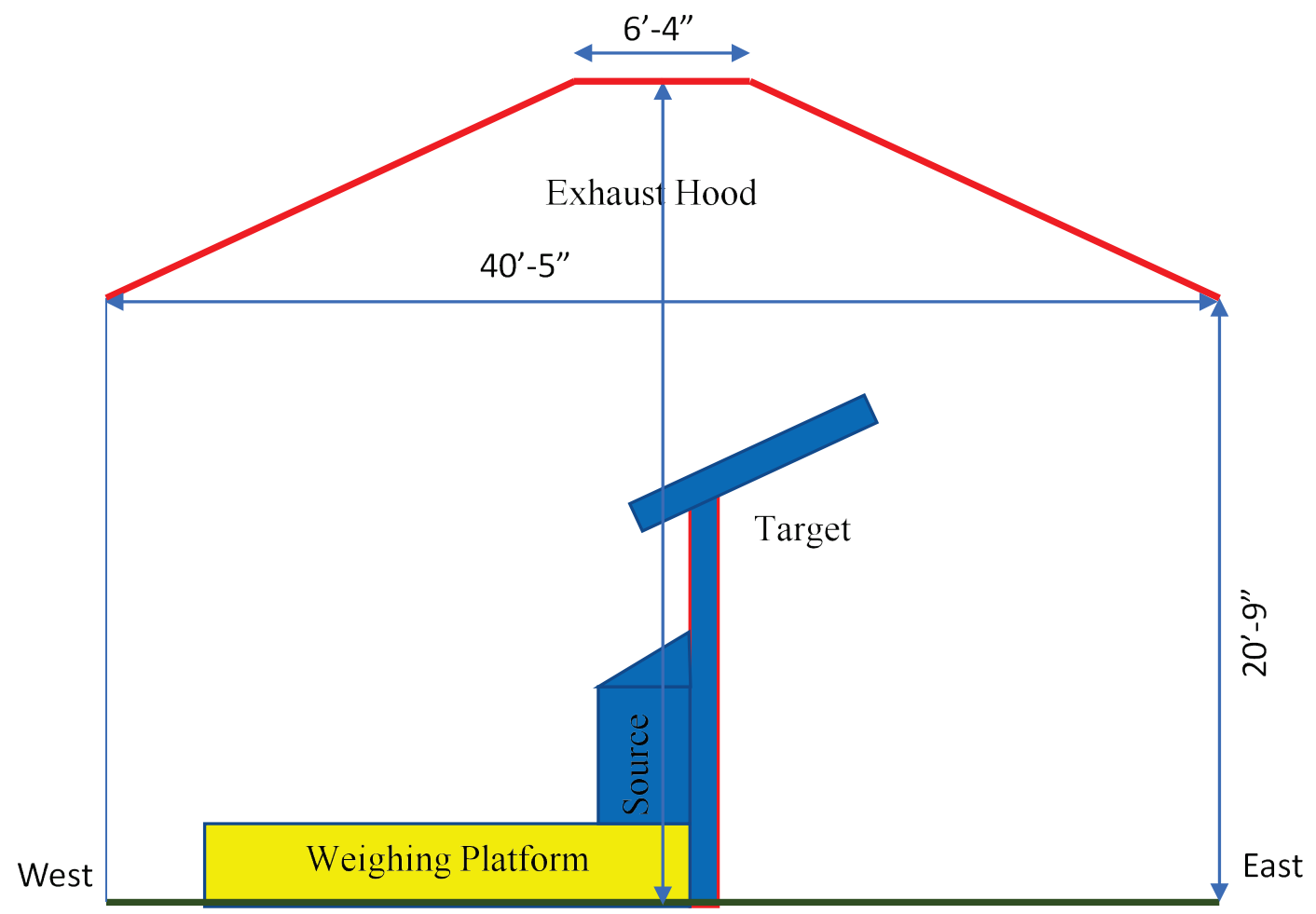

Figure 5: Target and source placement under the $10 \mathrm{MW}$ exhaust hood (figure not to scale). 


\subsubsection{Weighing platform}

A rectangular platform constructed using lightweight modular trusses covered with fireresistant decking layers will be used to determine mass loss rate of the fire sources during the Phase $1 \mathrm{~B}$ burn experiments. A schematic elevation drawing of the platform at one corner is shown in Figure 6 . The nominal plan dimensions of the platform are $5.8 \mathrm{~m} \times 5.8 \mathrm{~m}$ $(19 \mathrm{ft} \times 19 \mathrm{ft})$. The fixtures for the weighing modules located at each corner of the platform are designed to allow for expected rotation (due to bending) and translation (due to axial thermal expansion) of the platform during fire testing. No applied horizontal loads (due to wind load) will be present for the Phase 1B NIST shed burn experiments. See Appendix B for additional details on the weighing platform design.

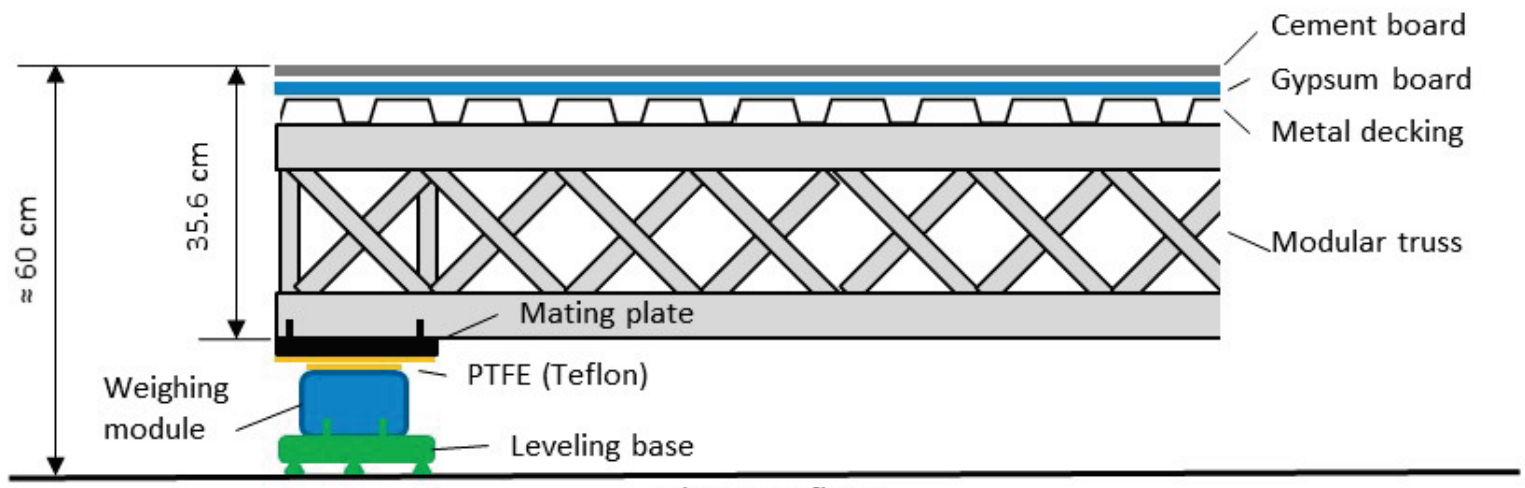

Laboratory floor

Figure 6: Schematic elevation drawing of the weighing platform at one corner (figure not to scale).

\subsubsection{Fire ignition}

Wood cribs inside the source structures will be ignited using a known amount of n-heptane placed in aluminum pans of known dimensions.

\subsubsection{Instrumentation and data collection system}

a. A total of six heat flux gages will be used for heat flux measurements. Heat flux gages will be oriented perpendicular to the target structure or the long axis of the shed. Heat flux gages will be placed $1 \mathrm{~m}(3.2 \mathrm{ft})$ and $2 \mathrm{~m}(6.5 \mathrm{ft})$ above the weighing platform. HF1 and HF2 will be placed nominally at a distance of $2 \mathrm{~m}(6.5 \mathrm{ft})$ from the shed. HF3 and HF4 will be placed at a distance of $3 \mathrm{~m}(9.8 \mathrm{ft})$ and HF5 and HF6 will be placed at a distance of $4 \mathrm{~m}(13.1 \mathrm{ft})$.

b. Three sets of plate thermocouples (facing down) along with bare bead thermocouples will be used to measure temperatures and subsequently estimate heat fluxes at three heights above the source (shed) center.

c. The weighing platform described in Section 4.2 .2 will be used to measure the mass loss rate. 
d. Heat release rate measurements will be performed using oxygen consumption calorimetry.

e. Video cameras will be used to record the fire events.

f. A LABVIEW data acquisition (DAQ) system will be used to sample the output from the heat flux sensors, thermocouples, anemometers, and load cells at $1 \mathrm{~Hz} .^{3}$

\subsubsection{Targets}

Target structures will be designed and modified depending on the failures observed during preliminary burns. For example, if the target structure fails prematurely at the window, the window will be eliminated from the target structure assembly. Specifics on the target structure designs are listed below.

a. The target structure will be comprised of a roof-wall assembly with a vented attic. An asphalt shingle roof with a roof pitch of 5:12 and open eave configuration will be used. 2" $\times 4$ " studs will be used for the construction of wall with $5 / 8$ " drywall and 1 " thick mineral fiber cavity insulation. The exterior will have 7/16" thick oriented strand board (OSB) and one layer of cement board. Preliminary drawings and material specifications are provided in Appendix C. The actual design and material specifications for the target wall may vary and will be described in detail in subsequent report.

b. Target walls/window assemblies (Figure 7) will be designed with a double pane window to face temporal heat flux exposures that result in window cracking, paint blistering, and vinyl deforming/melting. The target wall will have nominal dimensions of $3.9 \mathrm{~m}$ (tall) $\times 4.87 \mathrm{~m}$ (wide) $(13 \mathrm{ft} \times 16 \mathrm{ft})$ to accommodate the source structure (with a maximum height of $2.43 \mathrm{~m}(8 \mathrm{ft})$ ) under the window. A single hung, double-pane vinyl window will be placed $2.59 \mathrm{~m}(8.5 \mathrm{ft})$ above the foundation and will have nominal dimensions of $0.61 \mathrm{~m}$ (high) $\times 0.91 \mathrm{~m}$ (wide) $(2 \mathrm{ft} \times 3 \mathrm{ft})$. Similar window configurations are commonly used in bathrooms, for example. The total height of the target structure including the foundation and the roof will be approximately $5.28 \mathrm{~m}\left(17^{\prime}-4\right.$ ").

c. The eave vent plenum (Figure 8) situated behind the eave vents and under the roof, simulating an attic area, will be equipped with negative pressure exhaust fan. The fan used to draw air through the vent will have variable speed control adjustment to deliver an average speed of $0.9 \mathrm{~m} / \mathrm{s}(2.0 \mathrm{mi} / \mathrm{h})$. A K6 series inline centrifugal fan $(115 \mathrm{~V}$, maximum $84 \mathrm{~W}$ and $0.74 \mathrm{~A}$, nominal $2680 \mathrm{rev} / \mathrm{min})$ specified in ASTM E 2886 [3] will be used. Two thermocouples will be placed inside the plenum to measure the maximum temperature reached on the unexposed side of the target wall. A $100 \%$ cotton batting with a density in the range of $20 \mathrm{~kg} / \mathrm{m}^{3}$ and $25 \mathrm{~kg} / \mathrm{m}^{3}$ will be used as the combustible target material inside the plenum. Specifications and conditioning requirements for the combustible target material are provided in ASTM E 2886 [3]. Flame penetration through the vents and ignition of the combustible target material will be monitored using a video camera.

\footnotetext{
${ }^{3}$ The Heat Release Rate Measurements for Phase 1B will be made on an independent data collection system already in place in the NFRL.
} 


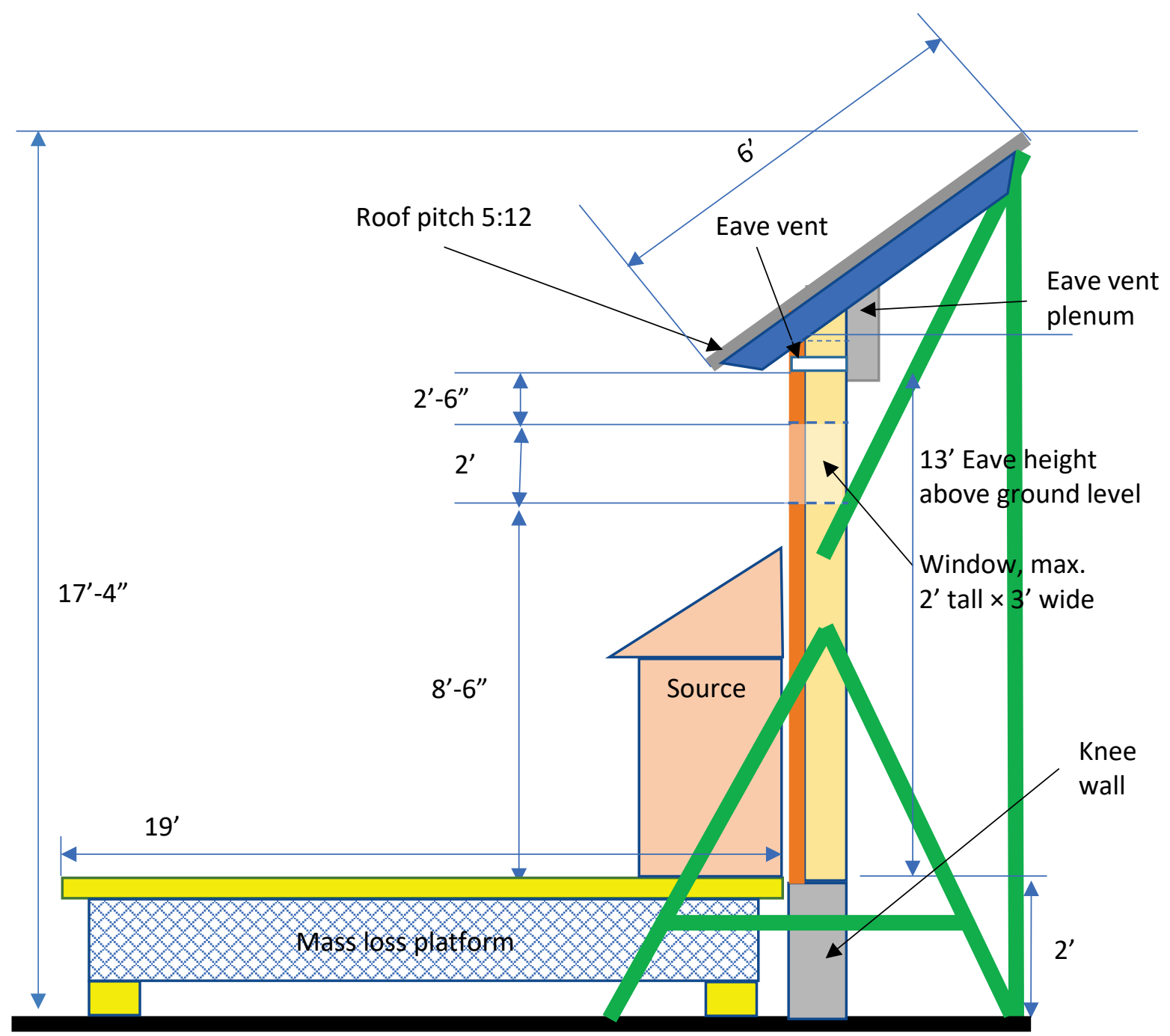

Figure 7: Target structure and source (closet or very small shed) configuration (figure not to scale $).(1 \mathrm{ft}=0.0305 \mathrm{~m})$ 


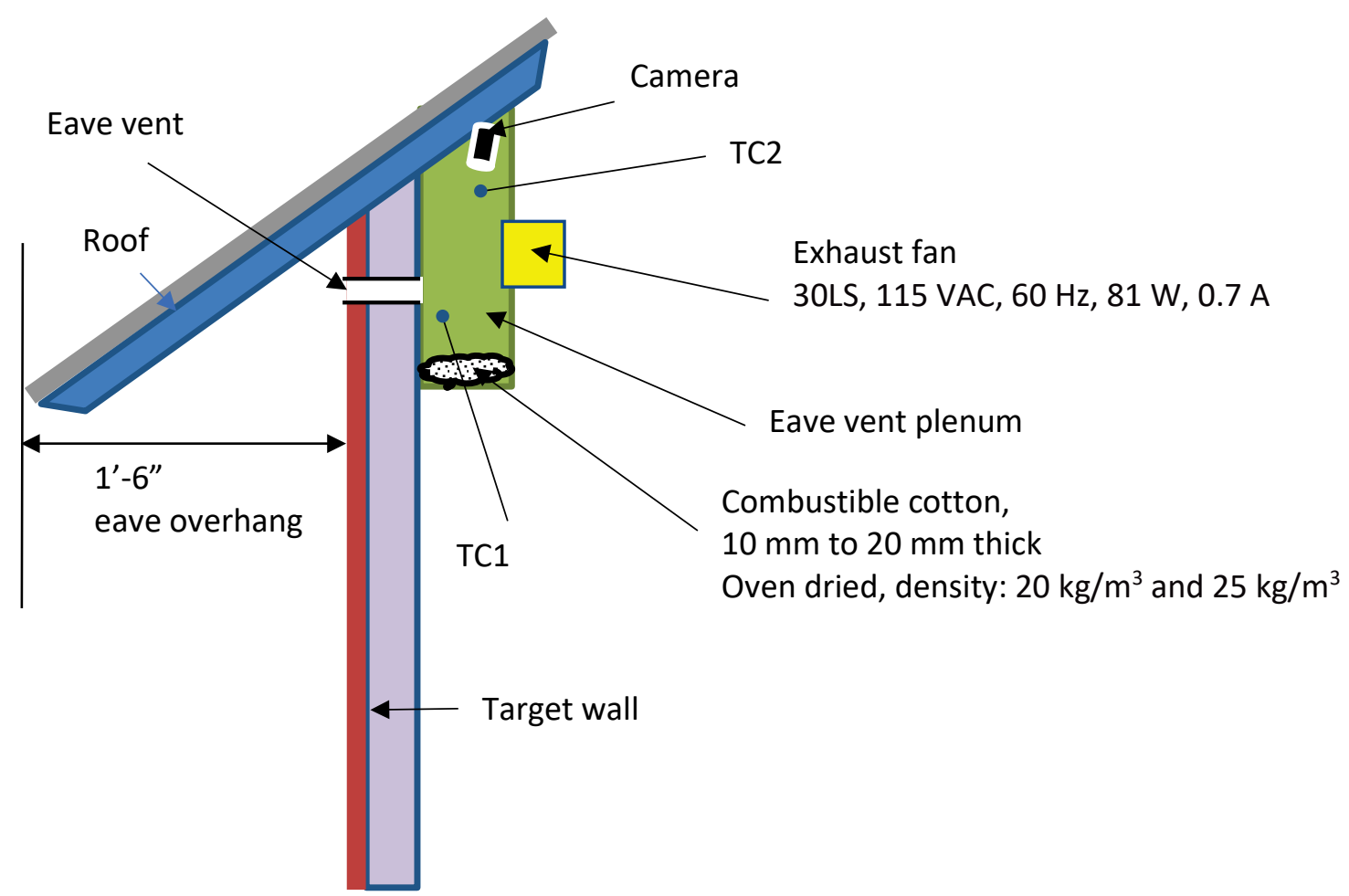

Figure 8: Eave vent plenum design (figure not to scale). $(1 \mathrm{ft}=0.0305 \mathrm{~m}$ ) 


\subsection{Preliminary burns}

Preliminary experiments will be conducted to measure integrated heat flux on steel plates that will be used in place of eaves and the window. Heat flux data will be calculated by using temperature measurements from steel plates instrumented with thermocouples.

\subsubsection{Preliminary burn objectives}

1. Investigate eaves/roof response to convective and radiant heat exposure from natural gas burner.

2. Collect heat transfer data using steel plates with thermocouples.

3. Provide insights into design and construction of target structure.

These objectives will be accomplished by performing following three experiments:

1. Experiment 1: The eaves and the window steel plates will be exposed to the natural gas burner with initial heat output of $200 \mathrm{~kW}$, and the exposure will be increased in steps of $200 \mathrm{~kW}$. Maximum heat output for this experiment will be $600 \mathrm{~kW}$. Temperature data will be recorded during exposure to the gas burner and during the cooling period.

2. Experiment 2: Experiment 1 will be repeated with gas burner moved $1.5 \mathrm{~m}(5 \mathrm{ft})$ away from the target wall.

3. Experiment 3: The eaves and the window steel plates will be exposed to the gas burner, and the output of the gas burner will be increased until intermittent flame contact with the steel plates is observed. Warping of steel plates will also be monitored during this test with higher burner output. The gas burner will be turned off as soon as warping of steel plates is observed. Maximum heat output of the burner at which warping or intermittent flame contact with the steel plates replacing eaves will be noted.

The results of these experiments will help design and construction of target structure for subsequent shed burn experiments.

These preliminary experiments will be conducted under the $8.4 \mathrm{~m} \times 12.4 \mathrm{~m}(27.6 \mathrm{ft} \times 40.7 \mathrm{ft})$ hood. The gas burners have nominal dimensions of $1 \mathrm{~m} \times 1.5 \mathrm{~m}(3.2 \mathrm{ft} \times 4.9 \mathrm{ft})$. The plan and cross-sectional views of the gas burner pan and distribution manifold are provided in Figure 9. The tests will utilize a natural gas burner with maximum heat output of $1 \mathrm{MW}$. Placement of the burner with respect to the target structure (non-combustible wall) used in the preliminary burns is shown in Figure 10. The gas burner will be placed on the ground such that the distance between the top of the burner and the eaves is approximately $1.8 \mathrm{~m}$ $(6 \mathrm{ft})$. The front and top view of the instrumented target wall is shown in Figure 11. The top view of experimental set-up under the exhaust hood is shown in Figure 12. 

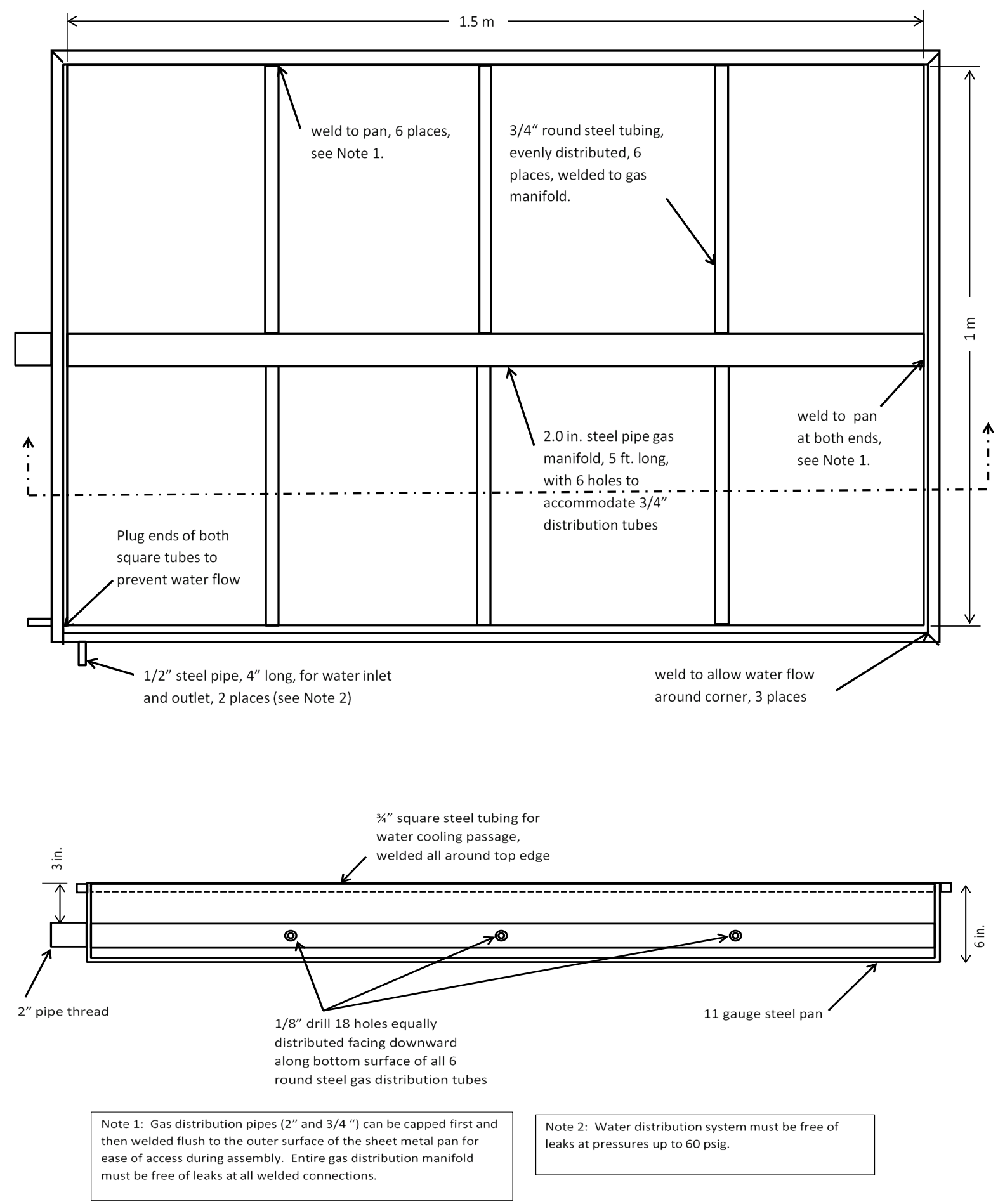

Figure 9: Plan and a cross-sectional view of $1.5 \mathrm{~m} \times 1.0 \mathrm{~m}$ gas burner pan and distribution manifold (figure not to scale). 


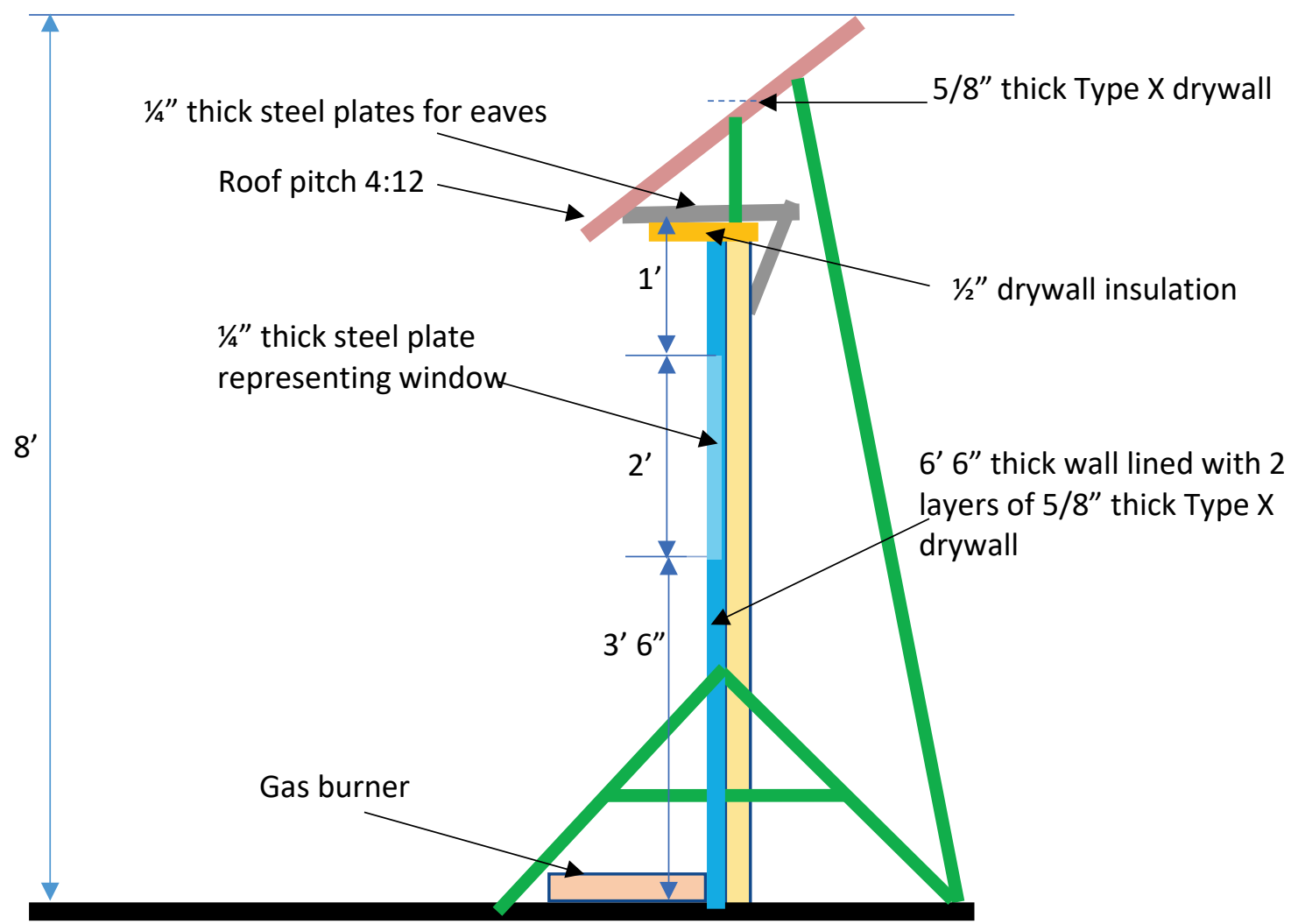

Figure 10: Non-combustible instrumented target structure for preliminary burns (figure not to scale $).(1 \mathrm{ft} .=0.0305 \mathrm{~m})$ 
Front view of wall, eaves (Top Plates), window, and burner

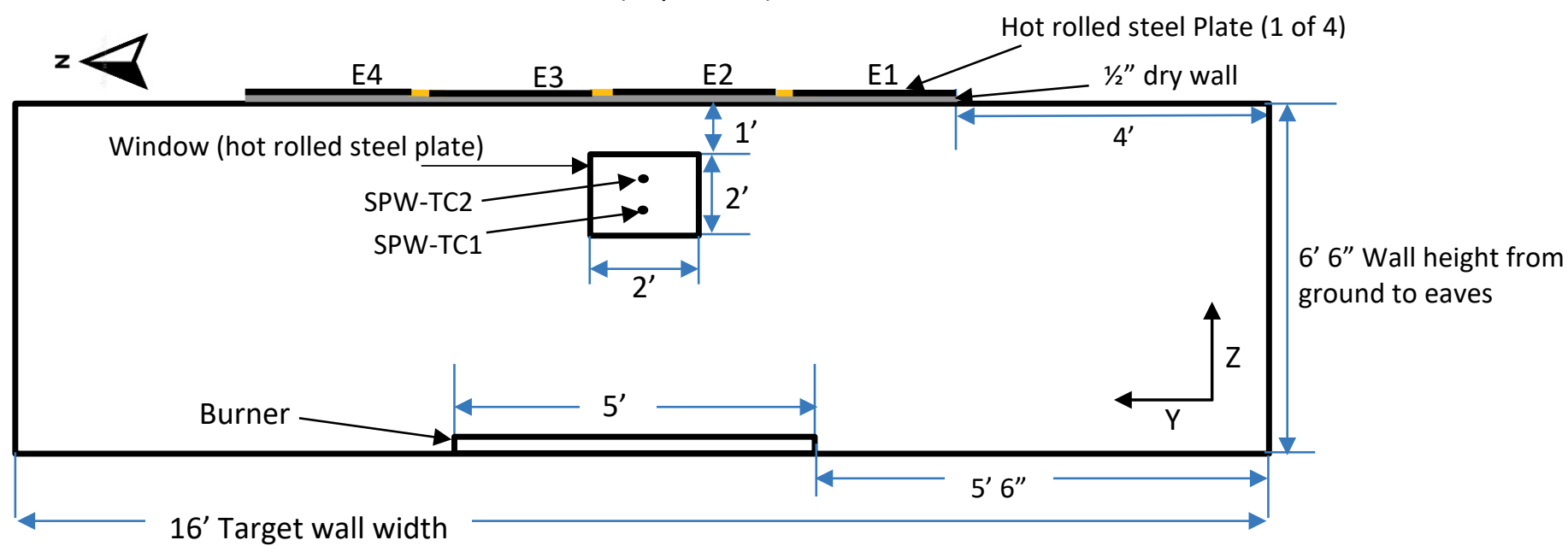

Top view of wall and eaves (Top Plates)

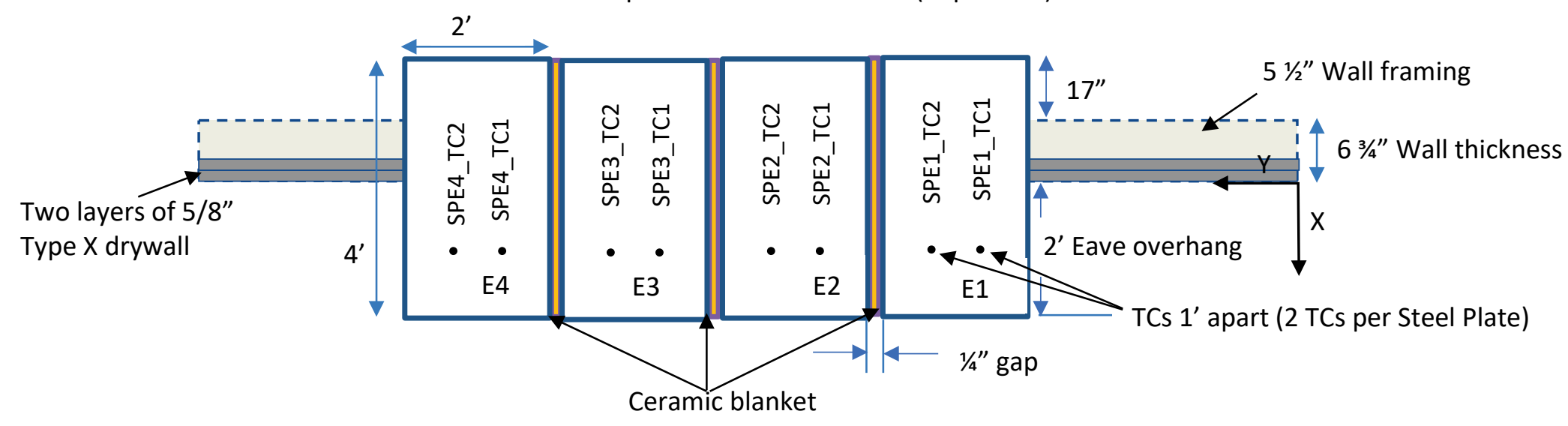

Figure 11: Front and top view of the instrumented target wall used in preliminary burns (figure not to scale). $(1 \mathrm{ft}=0.0305 \mathrm{~m}$ ) 


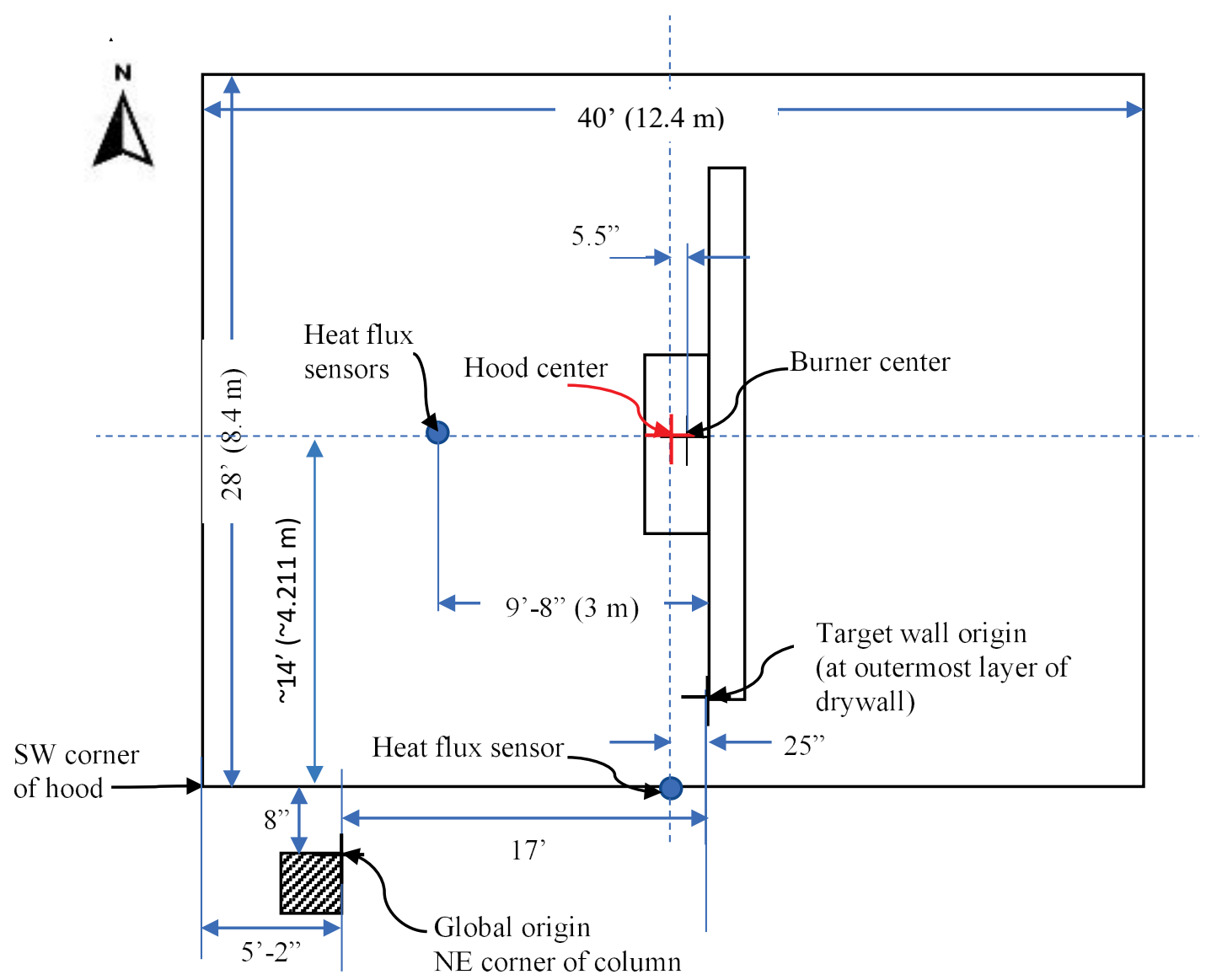

Figure 12. Top view of experimental set-up under the hood.

\subsubsection{Instrumentation}

The target structure for the preliminary burn experiments will include a non-combustible wall, roof, and the eaves. The nominal dimensions of the target structure will be $8 \mathrm{ft}(\mathrm{tall}) \times$ $16 \mathrm{ft}$ (wide). Target wall assembly is as shown in Figure 10. The front and top view of the instrumented target wall is shown in Figure 11. The non-combustible wall will be lined with two layers of $5 / 8$ " inch thick gypsum boards whereas the roof will be covered with insulating ceramic blanket. Hot rolled steel plates will replace eaves $(2 \mathrm{ft} \times 4 \mathrm{ft} \times 1 / 4 \mathrm{inch})$ and the window $(2 \mathrm{ft} \times 2 \mathrm{ft} \times 1 / 4 \mathrm{inch})$ on the wall. Nominal location of the thermocouples on the steel plates is shown in Figure 11. 


\subsection{Phase 1B HRR test matrix}

The primary test parameters for the Phase $1 \mathrm{~B}$ experiments at NIST are summarized in Table 4. To establish a baseline for the heat release rate (HRR), mass loss rate (MLR) of the fuel sources, wood cribs in the low, medium, and high fuel loading configurations for the very small shed (see Appendix A for fuel load details) will be measured in triplicate as shown in Table 5. Subsequently, the experiments with the sources, fuel loading, and targets will be conducted. The space of possible tests is summarized in Table 6; however, only a subset of these will be executed following the prioritization scheme described in Section 4.4.1. Depending on the availability of funds and time permitting, sheds without fuel loading or a target structure may be tested as shown in Table 7 .

The test naming convention for Phase 1 is as follows: Phase (1A or 1B) - Material (Wood (W), Steel (S), Plastic/Composite (P), California Building Code Chapter 7A construction (7A)), Size (Closet (C), Very Small (VS), Small (S), Medium (M), Large (L), Very Large $(\mathrm{VL}))$, Fuel Loading $(\mathrm{l}, \mathrm{m}, \mathrm{h})$, Wind speed $(\mathrm{w}(\mathrm{mi} / \mathrm{h}))$ - structure separation distance $(S S D)$ (ft). The letter "R" followed by a number at the end of the test name indicates a test replicate. For example, the first repeat for a very small wooden shed with high fuel loading, $8.9 \mathrm{~m} / \mathrm{s}$ $(20 \mathrm{mi} / \mathrm{h})$ wind, and $3.04 \mathrm{~m}(10 \mathrm{ft}) \mathrm{SSD}$ will have test number 1B-WVSh20-10-R1.

Table 4: Test parameters for Phase 1B NIST experiments $(1 \mathrm{ft}=0.0305 \mathrm{~m})$.

\begin{tabular}{|c|c|c|}
\hline $\begin{array}{c}\text { Source Structure } \\
\text { Construction }\end{array}$ & Source Structure Size & Fuel Loading \\
\hline \multirow{2}{*}{ Wood } & Closet $(3 \mathrm{ft} \times 5 \mathrm{ft})<75 \mathrm{ft}^{3}$ & \multirow{2}{*}{ Low } \\
\cline { 2 - 2 } Steel & Very Small $(4 \mathrm{ft} \times 4 \mathrm{ft})<150 \mathrm{ft}^{3}$ & Medium \\
\cline { 2 - 2 } & Small $(4 \mathrm{ft} \times 8 \mathrm{ft})<300 \mathrm{ft}^{3}$ & High \\
\cline { 2 - 3 } Plastic/Composite & Medium $(8 \mathrm{ft} \times 8 \mathrm{ft})>300 \mathrm{ft}^{3}$ & \\
\hline
\end{tabular}

Table 5: Experiments to characterize fuel loading for Phase 1B NIST experiments (wood cribs only).

\begin{tabular}{|c|c|c|}
\hline Serial Number & Test ID & Fuel Loading \\
\hline 1 & 1B-1 & \multirow{3}{*}{ Low } \\
\hline 2 & 1B-1-R1 & \\
\hline 3 & 1B-1-R2 & \\
\hline 4 & 1B-h & \multirow{3}{*}{ High } \\
\hline 5 & 1B-h-R1 & \\
\hline 6 & 1B-h-R2 & \\
\hline 7 & $1 \mathrm{~B}-\mathrm{m}$ & \multirow{3}{*}{ Medium } \\
\hline 8 & 1B-m-R1 & \\
\hline 9 & 1B-m-R2 & \\
\hline
\end{tabular}


Table 6: Possible test space for Phase 1B NIST shed burn experiments (no wind).

\begin{tabular}{|c|c|c|c|c|c|c|}
\hline \begin{tabular}{l|} 
Serial \\
Number
\end{tabular} & Test ID & $\begin{array}{l}\text { Source } \\
\text { Construction }\end{array}$ & $\begin{array}{l}\text { Source } \\
\text { Size } \\
\end{array}$ & $\begin{array}{l}\text { Fuel } \\
\text { Loading } \\
\end{array}$ & $\begin{array}{l}\text { Target } \\
\text { Structure }\end{array}$ & SSD \\
\hline 1 & 1B-WCh0-0 & \multirow{14}{*}{ Wood } & Closet & High & Yes & 0 \\
\hline 2 & 1B-WVS10 & & \multirow{3}{*}{$\begin{array}{l}\text { Very } \\
\text { Small }\end{array}$} & Low & No & $\mathrm{n} / \mathrm{a}$ \\
\hline 3 & 1B-WVSh0 & & & High & No & $\mathrm{n} / \mathrm{a}$ \\
\hline 4 & 1B-WVSh0-0 & & & High & Yes & 0 \\
\hline 5 & 1B-WS10 & & \multirow{3}{*}{ Small } & Low & No & $\mathrm{n} / \mathrm{a}$ \\
\hline 6 & 1B-WSh0 & & & High & No & $\mathrm{n} / \mathrm{a}$ \\
\hline 7 & 1B-WSh0-0 & & & High & Yes & 0 \\
\hline 8 & 1B-WM10 & & \multirow{5}{*}{ Medium } & Low & No & $\mathrm{n} / \mathrm{a}$ \\
\hline 9 & 1B-WMm 0 & & & Medium & No & $\mathrm{n} / \mathrm{a}$ \\
\hline 10 & $\begin{array}{l}\text { 1B-WMh0- } \\
\text { TBD }\end{array}$ & & & High & Yes & TBD \\
\hline 11 & 1B-7AMh0† & & & High & No & $\mathrm{n} / \mathrm{a}$ \\
\hline 12 & $\begin{array}{l}\text { 1B-7AMh0- } \\
\text { TBD } \dagger\end{array}$ & & & High & Yes & TBD \\
\hline 13 & 1B-Wxx0-0-R1 & & \multirow{2}{*}{ TBD } & TBD & Yes & 0 \\
\hline 14 & 1B-Wxx0-0-R2 & & & & Yes & 0 \\
\hline 15 & 1B-SCh0-0 & \multirow{11}{*}{ Steel $\$$} & Closet & High & Yes & 0 \\
\hline 16 & 1B-SVS10 & & \multirow{3}{*}{$\begin{array}{l}\text { Very } \\
\text { Small }\end{array}$} & Low & No & $\mathrm{n} / \mathrm{a}$ \\
\hline 17 & 1B-SVSh0 & & & High & No & $\mathrm{n} / \mathrm{a}$ \\
\hline 18 & 1B-SVSh0-0 & & & High & Yes & 0 \\
\hline 19 & 1B-SS10 & & \multirow{4}{*}{ Small } & Low & No & $\mathrm{n} / \mathrm{a}$ \\
\hline 20 & 1B-SSm0 & & & Medium & No & $\mathrm{n} / \mathrm{a}$ \\
\hline 21 & 1B-SSh0 & & & High & No & $\mathrm{n} / \mathrm{a}$ \\
\hline 22 & 1B-SSh0-0 & & & High & Yes & 0 \\
\hline 23 & 1B-SM10 & & \multirow{3}{*}{ Medium } & Low & No & $\mathrm{n} / \mathrm{a}$ \\
\hline 24 & 1B-SMm0 & & & Medium & No & $\mathrm{n} / \mathrm{a}$ \\
\hline 25 & 1B-SMh0-TBD & & & High & Yes & TBD \\
\hline 26 & 1B-PCh0-0 & \multirow{10}{*}{$\begin{array}{l}\text { Plastic/ } \\
\text { Composite }\end{array}$} & Closet & High & Yes & 0 \\
\hline 27 & 1B-PVS10 & & \multirow{3}{*}{$\begin{array}{l}\text { Very } \\
\text { Small }\end{array}$} & Low & No & $\mathrm{n} / \mathrm{a}$ \\
\hline 28 & 1B-PVSh0 & & & High & No & $\mathrm{n} / \mathrm{a}$ \\
\hline 29 & 1B-PVSh0-0 & & & High & Yes & 0 \\
\hline 30 & 1B-PS10 & & \multirow{3}{*}{ Small } & Low & No & $\mathrm{n} / \mathrm{a}$ \\
\hline 31 & 1B-PSh0 & & & High & No & $\mathrm{n} / \mathrm{a}$ \\
\hline 32 & 1B-PSh0-0 & & & High & Yes & 0 \\
\hline 33 & 1B-PM10 & & \multirow{3}{*}{ Medium } & Low & No & $\mathrm{n} / \mathrm{a}$ \\
\hline 34 & 1B-PMm0 & & & Medium & No & $\mathrm{n} / \mathrm{a}$ \\
\hline 35 & 1B-PMh0-TBD & & & High & Yes & TBD \\
\hline
\end{tabular}

$S S D=$ structure separation distance; $T B D=$ To be determined; $n / a=$ not applicable

+ Chapter 7 A compliant walls will be assessed.

$\neq$ Select steel construction tests may investigate door open versus door closed scenarios. 
Table 7: Sheds only (optional).

\begin{tabular}{|l|l|l|l|l|l|l|}
\hline $\begin{array}{l}\text { Serial } \\
\text { Number }\end{array}$ & Test ID & $\begin{array}{l}\text { Source } \\
\text { Construction }\end{array}$ & Source Size & $\begin{array}{l}\text { Fuel } \\
\text { Loading }\end{array}$ & $\begin{array}{l}\text { Target } \\
\text { Structure }\end{array}$ & SSD \\
\hline 1 & 1B-WVS & Wood & Very Small & n/a & n/a & n/a \\
\hline 2 & 1B-7AVS & Chapter 7A Wood & Very Small & n/a & n/a & n/a \\
\hline 3 & 1B-WS & Wood & Small & n/a & n/a & n/a \\
\hline 4 & 1B-7AS & Chapter 7A Wood & Small & n/a & n/a & n/a \\
\hline 5 & 1B-PVS & Plastic/Composite & Very Small & n/a & n/a & n/a \\
\hline 6 & 1B-PS & Plastic/Composite & Small & n/a & n/a & n/a \\
\hline
\end{tabular}

$S S D=$ structure separation distance; $n / a=$ not applicable

\subsubsection{Prioritized NIST experiments}

The following conditional statements and flowchart in Figure 13 are developed to facilitate the decision making for the selection of follow-on tests based on the experimental results. The sequencing of the tests as prioritized using Figure 13 is shown in Table 8.

IF C with heavy fuel loading (FL) fail, THEN Repeat C with heavy FL

IF $\mathrm{C}$ with heavy FL repeatably fail, THEN Test $\mathrm{C}$ with low FL

IF C with heavy FL do not fail, THEN test VS with heavy FL

IF VS fail, THEN repeat VS

IF VS repeatably fail, THEN Test VS with low FL

IF VS with low FL do not fail, THEN test $\mathrm{S}$ with heavy FL

IF $S$ with heavy FL fail, THEN repeat $S$ with heavy FL

IF $S$ with heavy FL repeatedly fail, THEN test $S$ with low FL

IF $\mathrm{S}$ with low FL do not fail, THEN test $\mathrm{M}$ with heavy FL

IF $M$ with heavy FL fail, THEN repeat $M$ with heavy FL

IF $M$ with heavy FL repeatedly fail, THEN test $M$ with low FL 
Table 8: Priority sequence for NIST NFRL testing.

\begin{tabular}{|c|c|c|c|c|c|c|}
\hline $\begin{array}{l}\text { Serial } \\
\text { Number }\end{array}$ & Test ID & $\begin{array}{l}\text { Source } \\
\text { Construction }\end{array}$ & Source Size & \begin{tabular}{|l|} 
Fuel \\
Loading
\end{tabular} & $\begin{array}{l}\text { Target } \\
\text { Structure }\end{array}$ & SSD \\
\hline \multicolumn{7}{|c|}{ Shed testing for HRR and MLR } \\
\hline 1 & 1B-WCh0 & Wood & Closet & High & $\mathrm{n} / \mathrm{a}$ & $\mathrm{n} / \mathrm{a}$ \\
\hline 2 & 1B-WCh0-R1 & Wood & Closet & High & $\mathrm{n} / \mathrm{a}$ & $\mathrm{n} / \mathrm{a}$ \\
\hline 3 & 1B-WCh0-R2 & Wood & Closet & High & $\mathrm{n} / \mathrm{a}$ & $\mathrm{n} / \mathrm{a}$ \\
\hline 4 & 1B-WVSh0 & Wood & Very Small & High & $\mathrm{n} / \mathrm{a}$ & $\mathrm{n} / \mathrm{a}$ \\
\hline 5 & 1B-PVSh0 & Plastic & Very Small & High & $\mathrm{n} / \mathrm{a}$ & $\mathrm{n} / \mathrm{a}$ \\
\hline 6 & 1B-SVSh0 & Steel & Very Small & High & $\mathrm{n} / \mathrm{a}$ & $\mathrm{n} / \mathrm{a}$ \\
\hline 7 & 1B-WCl0 & Wood & Closet & Low & $\mathrm{n} / \mathrm{a}$ & $\mathrm{n} / \mathrm{a}$ \\
\hline 8 & 1B-SC10 & Steel & Closet & Low & $\mathrm{n} / \mathrm{a}$ & $\mathrm{n} / \mathrm{a}$ \\
\hline 9 & 1B-PC10 & Plastic & Closet & Low & $\mathrm{n} / \mathrm{a}$ & $\mathrm{n} / \mathrm{a}$ \\
\hline \multicolumn{7}{|c|}{ Shed with Target Structure } \\
\hline 1 & 1B-WC10-0 & Wood & Closet & Low & Yes & 0 \\
\hline 2 & 1B-WC10-0-R1* & Wood & Closet & Low & Yes & 0 \\
\hline 3 & 1B-SVSh0-0 & Steel & Very Small & High & Yes & 0 \\
\hline 4 & 1B-SCh0-0 & Steel & Closet & High & Yes & 0 \\
\hline 5 & 1B-PCl0-0** & Plastic & Closet & Low & Yes & 0 \\
\hline 6 & 1B-PVS10** & Plastic & Very Small & Low & Yes & 0 \\
\hline
\end{tabular}

$S S D=$ structure separation distance; $T B D=$ To be determined; $n / a=$ not applicable

*If window fails in Test 1, window will be blocked to test different failure mode.

**With fan on. 


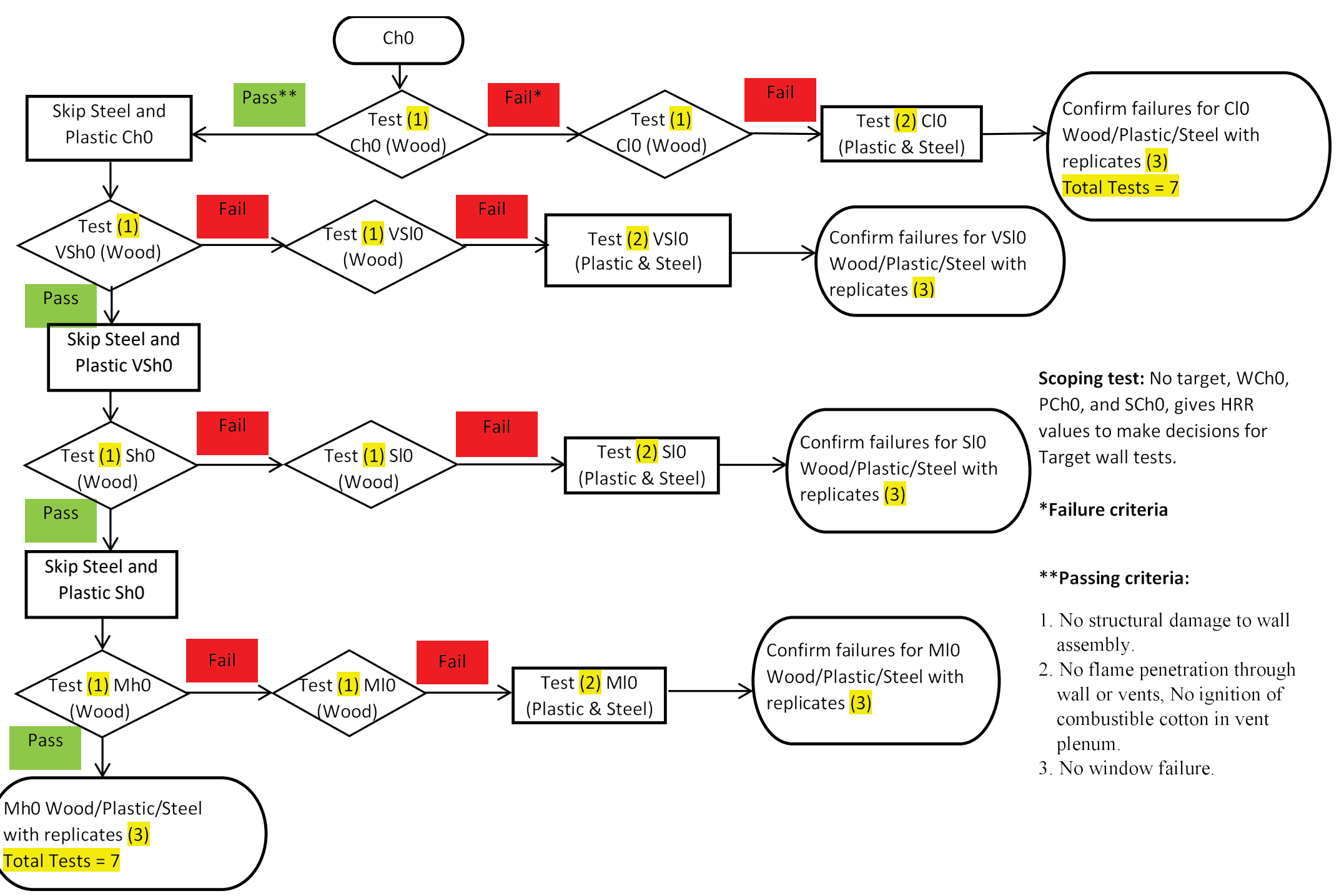

Figure 13: Conditional flowchart for developing NFRL test matrix. 
Table 9: Shed specifications for experiments at NIST NFRL $(1 \mathrm{ft}=0.0305 \mathrm{~m}, 1 \mathrm{lb}=0.453 \mathrm{~kg})$.

\begin{tabular}{|c|c|c|c|c|c|c|}
\hline $\begin{array}{l}\text { Wood } \\
\text { Sheds }\end{array}$ & Examples & $\begin{array}{c}\text { Size } \\
\mathbf{D} \times \mathbf{W} \times \mathbf{H}, \mathbf{f t}\end{array}$ & $\begin{array}{c}\text { Capacity, } \\
\mathrm{ft}^{3}\end{array}$ & $\begin{array}{c}\text { Door } \\
\mathbf{W} \times \mathbf{H}, \mathbf{f t}\end{array}$ & $\begin{array}{c}\text { Weight, } \\
\text { lb }\end{array}$ & Notes \\
\hline $\begin{array}{c}\text { Closet } \\
3 \mathrm{ft} \times 5 \mathrm{ft}\end{array}$ & Link & $2.1 \times 5 \times 4$ & 42 & $5.0 \times 3.9$ & 99 & $\begin{array}{l}\text { Double door } \\
\text { Roof material: wood } \\
\text { Construction material: Cypress wood } \\
\text { Floor: No } \\
\text { Vents: No }\end{array}$ \\
\hline $\begin{array}{l}\text { Very small } \\
4 \mathrm{ft} \times 4 \mathrm{ft}\end{array}$ & Link & $3 \times 6 \times 5.4$ & 97.2 & $5.0 \times 5.2$ & 172 & $\begin{array}{l}\text { Double door } \\
\text { Roof material: wood } \\
\text { Construction material: Cypress wood } \\
\text { Floor: not specified } \\
\text { Vents: No }\end{array}$ \\
\hline $\begin{array}{c}\text { Small } \\
4 \mathrm{ft} \times 8 \mathrm{ft}\end{array}$ & & $4 \times 8 \times 8$ & 256 & $5 \times 6$ & 740 & $\begin{array}{l}\text { Double door } \\
\text { Roof material: wooded shingles } \\
\text { Construction material: Western Red Cedar } \\
\text { wood } \\
\text { Floor: Plywood } \\
\text { Vents: No }\end{array}$ \\
\hline $\begin{array}{l}\text { Medium } \\
8 \mathrm{ft} \times 8 \mathrm{ft}\end{array}$ & Link & $8 \times 8 \times 8$ & 512 & $4 \times 6$ & 1060 & $\begin{array}{l}\text { Double door } \\
\text { Roof material: OSB sheeting } \\
\text { Construction material: Engineered wood, } \\
\text { LP Smart Siding } \\
\text { Floor: OSB } \\
\text { Vents: No }\end{array}$ \\
\hline
\end{tabular}




\section{Table 9 (cont.)}

\begin{tabular}{|c|c|c|c|c|c|c|}
\hline $\begin{array}{c}\text { Steel } \\
\text { Sheds }\end{array}$ & Examples & $\begin{array}{c}\text { Size } \\
\mathbf{D} \times \mathbf{W} \times \mathbf{H}, \mathbf{f t}\end{array}$ & $\begin{array}{c}\text { Capacity, } \\
\mathbf{f t}^{3}\end{array}$ & $\begin{array}{c}\text { Door } \\
\mathbf{W} \times \mathbf{H}, \mathbf{f t}\end{array}$ & $\begin{array}{c}\text { Weight, } \\
\text { lb }\end{array}$ & Notes \\
\hline $\begin{array}{c}\text { Closet } \\
3 \mathrm{ft} \times 5 \mathrm{ft}\end{array}$ & Link & $2.9 \times 5 \times 5.8$ & 84.1 & $5 \times 5$ & 93 & $\begin{array}{l}\text { Double door }+ \text { Lid } \\
\text { Roof material: Steel } \\
\text { Construction material: Galvanized } \\
\text { steel } \\
\text { Floor: not specified }\end{array}$ \\
\hline $\begin{array}{c}\text { Very } \\
\text { Small } \\
4 \mathrm{ft} \times 4 \mathrm{ft}\end{array}$ & ink & $2 \times 7 \times 6.8$ & 95.2 & $5.7 \times 4.1$ & 163 & $\begin{array}{l}\text { Single door } \\
\text { Roof material: Steel } \\
\text { Construction material: Galvanized } \\
\text { steel } \\
\text { Floor: not included } \\
\text { Vents: No } \\
\end{array}$ \\
\hline $\begin{array}{c}\text { Small } \\
4 \mathrm{ft} \times 8 \mathrm{ft}\end{array}$ & Link & $6 \times 6.3 \times 5.8$ & 219.2 & $2.6 \times 5$ & 109 & $\begin{array}{l}\text { Single sliding door } \\
\text { Roof material: Steel } \\
\text { Construction material: Galvanized } \\
\text { steel } \\
\text { Floor: not included } \\
\text { Vents: } 2\end{array}$ \\
\hline $\begin{array}{c}\text { Medium } \\
8 \mathrm{ft} \times 8 \mathrm{ft}\end{array}$ & Link & $7 \times 8 \times 7$ & 392 & $4.2 \times 5.8$ & 241 & $\begin{array}{l}\text { Double door } \\
\text { Roof material: Steel } \\
\text { Construction material: Galvanized } \\
\text { steel } \\
\text { Floor: not included } \\
\text { Vents: } 2 \text { gable vents }\end{array}$ \\
\hline
\end{tabular}




\begin{tabular}{|c|c|c|c|c|c|c|}
\hline $\begin{array}{l}\text { Plastic } \\
\text { Sheds }\end{array}$ & Examples & $\begin{array}{c}\text { Size } \\
\mathbf{D} \times \mathbf{W} \times \mathbf{H}, \mathbf{f t}\end{array}$ & $\begin{array}{c}\text { Capacity, } \\
\mathrm{ft}^{3} \\
\end{array}$ & $\begin{array}{c}\text { Door } \\
\mathbf{W} \times \mathbf{H}, \mathbf{f t} \\
\end{array}$ & $\begin{array}{c}\text { Weight, } \\
\text { lb }\end{array}$ & Notes \\
\hline $\begin{array}{c}\text { Closet } \\
3 \mathrm{ft} \times 5 \mathrm{ft}\end{array}$ & $\underline{\text { Link }}$ & $2.8 \times 4.9 \times 4$ & 54.8 & $4 \times 3.75$ & 56 & $\begin{array}{l}\text { Double door } \\
\text { Roof material: Plastic } \\
\text { Construction material: Plastic } \\
\text { Floor: Plastic } \\
\text { Vents: No }\end{array}$ \\
\hline $\begin{array}{c}\text { Very small } \\
4 \mathrm{ft} \times 4 \mathrm{ft}\end{array}$ & Link & $4 \times 5 \times 6.4$ & 128 & $4 \times 6$ & 155 & $\begin{array}{l}\text { Double door } \\
\text { Roof material: Plastic } \\
\text { Construction material: Plastic } \\
\text { Floor: Plastic } \\
\text { Vents: No }\end{array}$ \\
\hline $\begin{array}{c}\text { Small } \\
4 \mathrm{ft} \times 8 \mathrm{ft}\end{array}$ & Link & $4 \times 8 \times 6$ & 192 & $2.5 \times 5$ & 126 & $\begin{array}{l}\text { Single door } \\
\text { Roof material: Plastic } \\
\text { Construction material: Plastic (vinyl) } \\
\text { Floor: No } \\
\text { Vents: No }\end{array}$ \\
\hline $\begin{array}{l}\text { Medium } \\
8 \mathrm{ft} \times 8 \mathrm{ft}\end{array}$ & Link & $8 \times 8 \times 7.6$ & 486.4 & $4.2 \times 5.8$ & 128 & $\begin{array}{l}\text { Double doors } \\
\text { Roof material: Plastic } \\
\text { Construction material: Polycarbonate } \\
\text { Floor: No } \\
\text { Vents: } 4 \text { ( } 2 \text { in front and } 2 \text { at the back) }\end{array}$ \\
\hline
\end{tabular}




\subsection{Experimental outcome}

The expected outcomes from the Phase 1B NIST NFRL shed burn experiments are listed below.

a. Identify source size, construction details, and fuel loading for Phase 1B experiments at IBHS.

b. Identify ignition type for Phase 1B experiments at IBHS and Phase 2.

c. Identify instrumentation layout and types for Phase 1B experiments at IBHS and Phase 2.

d. Identify orientation of the door opening for source structure.

\subsection{Follow-on experiments}

In case the test program must be significantly truncated due to the behavior exhibited for the investigated specimens early in the testing, the following experiments may be conducted. If they are not conducted as part of Phase 1B, they will be deferred to Phase 2.

A non-combustible target wall as described in Section 4.2 .5 will be tested according to ASTM E 2957 [4]. Roof and eaves will be tested starting with $300 \mathrm{~kW}$ burner output. The burner will be similar to the one described in ASTME 2957 (Figure 14). Burner specifications are provided in Section 4.6.1 below. The target assembly design will be based on the outcomes of previous experiments. The heat output of the burner will be ramped up iteratively until ignition of the roof or eaves is observed. Once the heat output at which eaves and/or roof ignition occurs is identified, the roof and the eaves described in Section 4.2.5 will be replaced with non-combustible roof and eaves in the follow-on experiments. This noncombustible target assembly will be instrumented with heat flux gauges. The heat flux at the eaves from the burner output that led to ignition of eaves in previous experiments will be identified. 

a: Wood studs
b: Gypsum board
c: Gypsum board
d: Gas burner
e: Metal stand

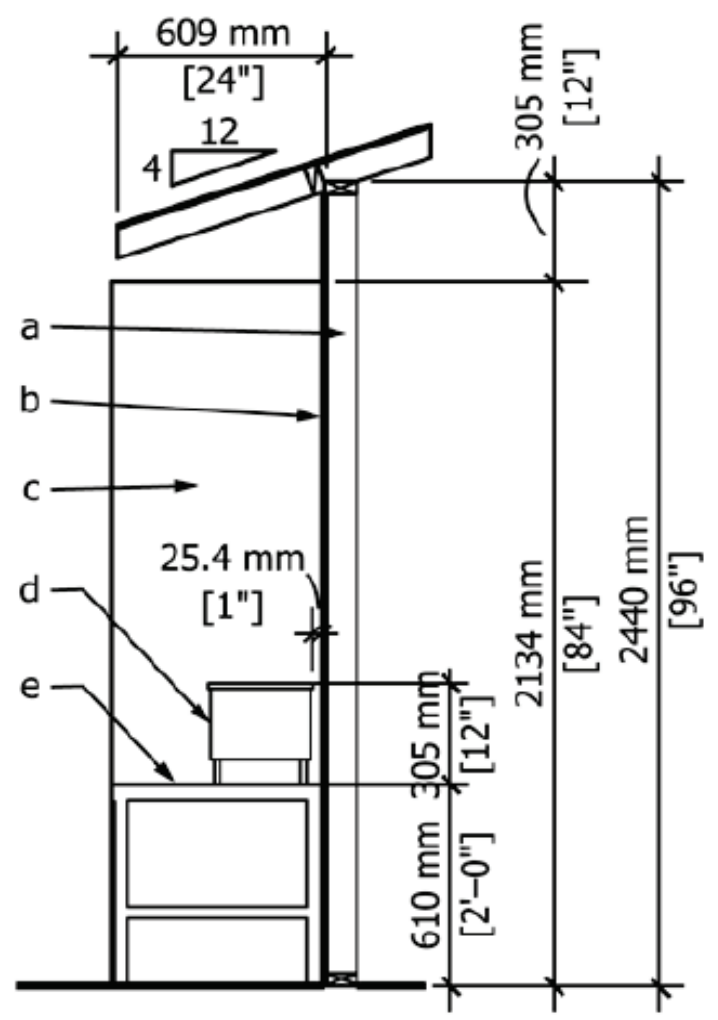

Figure 14: Target structure with roof and eaves and burner location [4]. 


\subsubsection{Burner specifications}

The ignition source for follow-on experiments will be a gas diffusion burner similar to the one used in ASTM E 2957 [4] and NFPA 286 [5]. The burner will have nominal dimensions of $305 \mathrm{~mm} \times 305 \mathrm{~mm} \times 152 \mathrm{~mm}(12 \mathrm{in} \times 12$ in $\times 6$ in), as shown in Figure 15. A $152 \mathrm{~mm}$ (6 in) tall metal stand supports the burner. The surface of the burner is covered with a $102 \mathrm{~mm}$ (4 in) layer of porous refractory material (Ottawa sand) often used as a diffuser. The gas burner is centered relative to the width of the wall assembly and is located $25 \mathrm{~mm}(1 \mathrm{in})$ from the wall assembly. The propane supply to the gas diffusion burner through a metered control system shall produce a net heat output of $300 \mathrm{~kW}$.
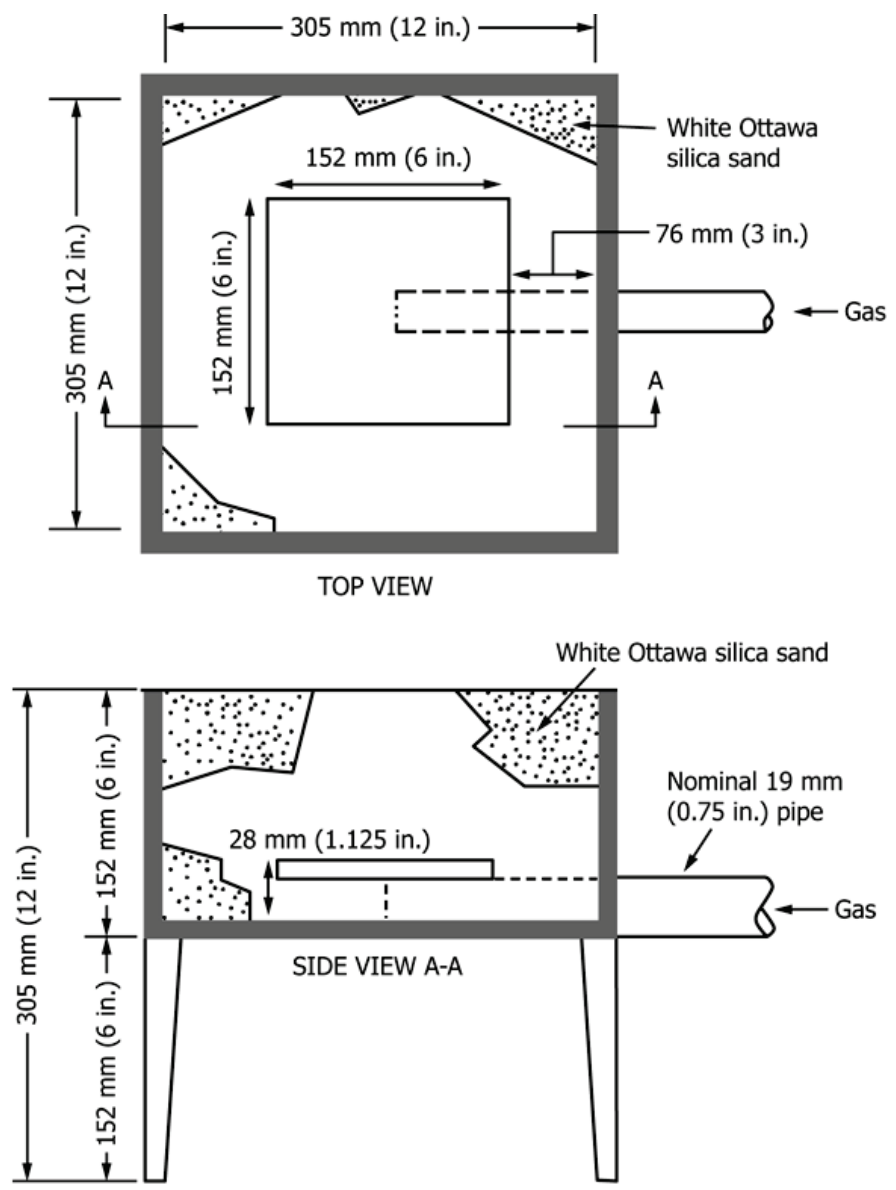

Figure 15: Gas diffusion burner dimensions [4].

\subsection{Modeling input and validation/verification}

Modeling will be used to design the experiments and to predict heat fluxes and wind flow on and around the target structure. See Section 6 for more information on modeling. 


\section{Phase 1B: IBHS Shed Burn Experiments (no HRR)}

Shed burn experiments at IBHS are divided into two parts. First, the exposure from small secondary structures will be quantified in terms of mass loss rate. These experiments will be performed with no wind. In the second set of experiments, the effect of wind on plume lean on the target structure will be studied. Safe structure separation distances for varying shed types will be determined. This section describes the test matrix, shed specifications, the target structure, instrumentation, and structure orientations for the Phase 1B IBHS shed burn experiments.

\section{Objectives}

1. Quantify exposure from small secondary structures (M, L, and VL sheds) in the presence of wind.

2. Quantify exposure from small secondary structures (M, L, and VL sheds) in terms of MLR with no wind.

3. Develop and test model prediction capabilities.

4. Use experiments and modeling to design Phase 2 and Phase 3.

\subsection{Technical issues}

The technical issues that will need to be addressed during the Phase 1B IBHS shed burn experiments are listed below.

a. Developing the modeling and prediction methodology.

b. Determining the construction type for source and targets for Phase 2 .

c. Identifying fuel loading of source building for Phase 2 .

d. Identifying instrumentation requirements for Phase 2 .

e. Identifying ignition requirements for Phase 2 (also see Modeling Section 6).

f. Determining the number of heat flux measurements (convective and radiative) during burn experiments with wind and a non-combustible target assembly

g. Determining the number and placement of the sensors during fire experiments.

h. Identifying the grid cell resolution for modeling of the fire experiments.

i. Identifying the capability to conduct Phase 2 experiments at IBHS.

\subsection{Location of experiments}

Experiments will be conducted at IBHS, outside the test cell on the concrete pad. The test area for this project is outlined by the yellow rectangle in Figure 16. The test area is approximately $13.7 \mathrm{~m} \times 67.05 \mathrm{~m}(45 \mathrm{ft} \times 150 \mathrm{ft})$. Figure 17 illustrates the approximate location of the target and source structures to be tested in Phase 1B. Figure 18 shows an aerial view of IBHS test facility with target and source structures at $45^{\circ}$ with an approximate structure separation distance of $6.0 \mathrm{~m}(20 \mathrm{ft})$. 


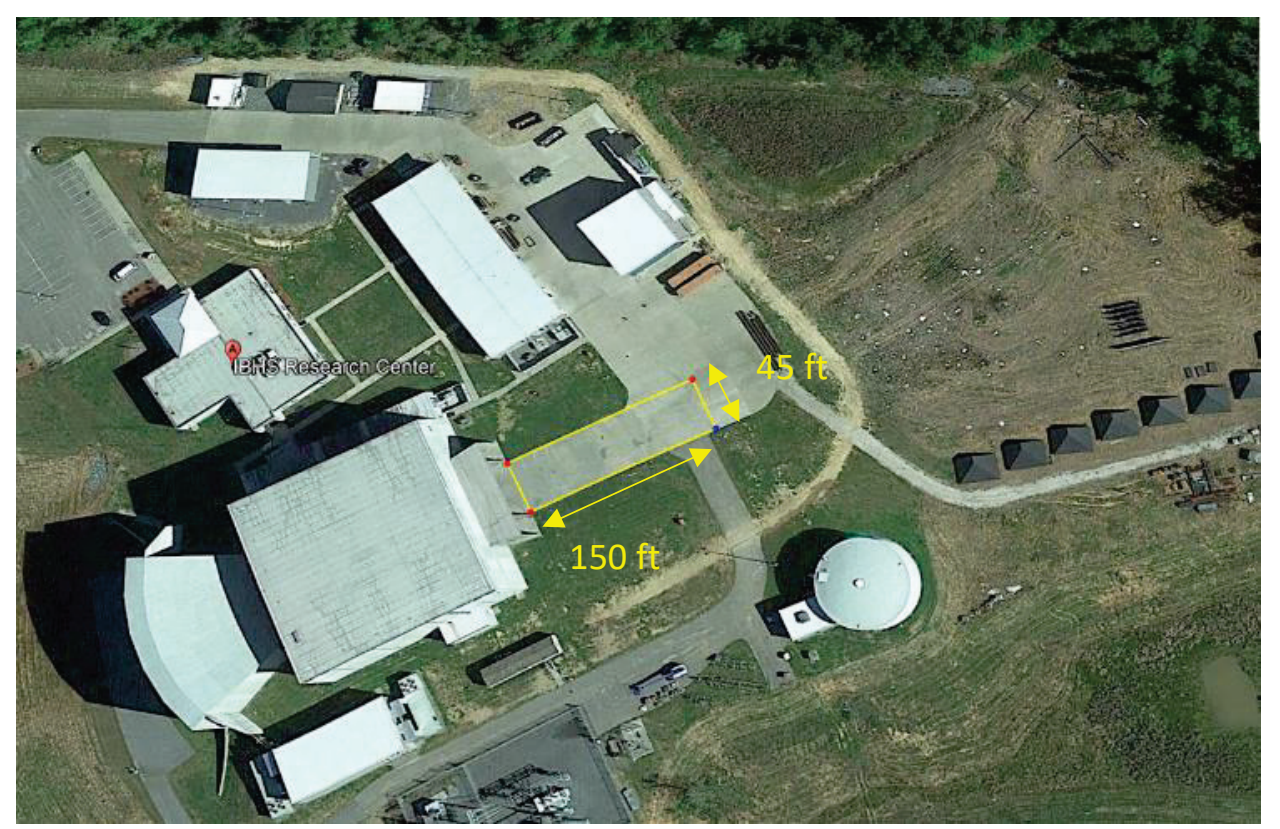

Figure 16: Aerial view of IBHS test facility (April 2018). Imagery: Google, Landsat/ Copernicus. Overlays: NIST.

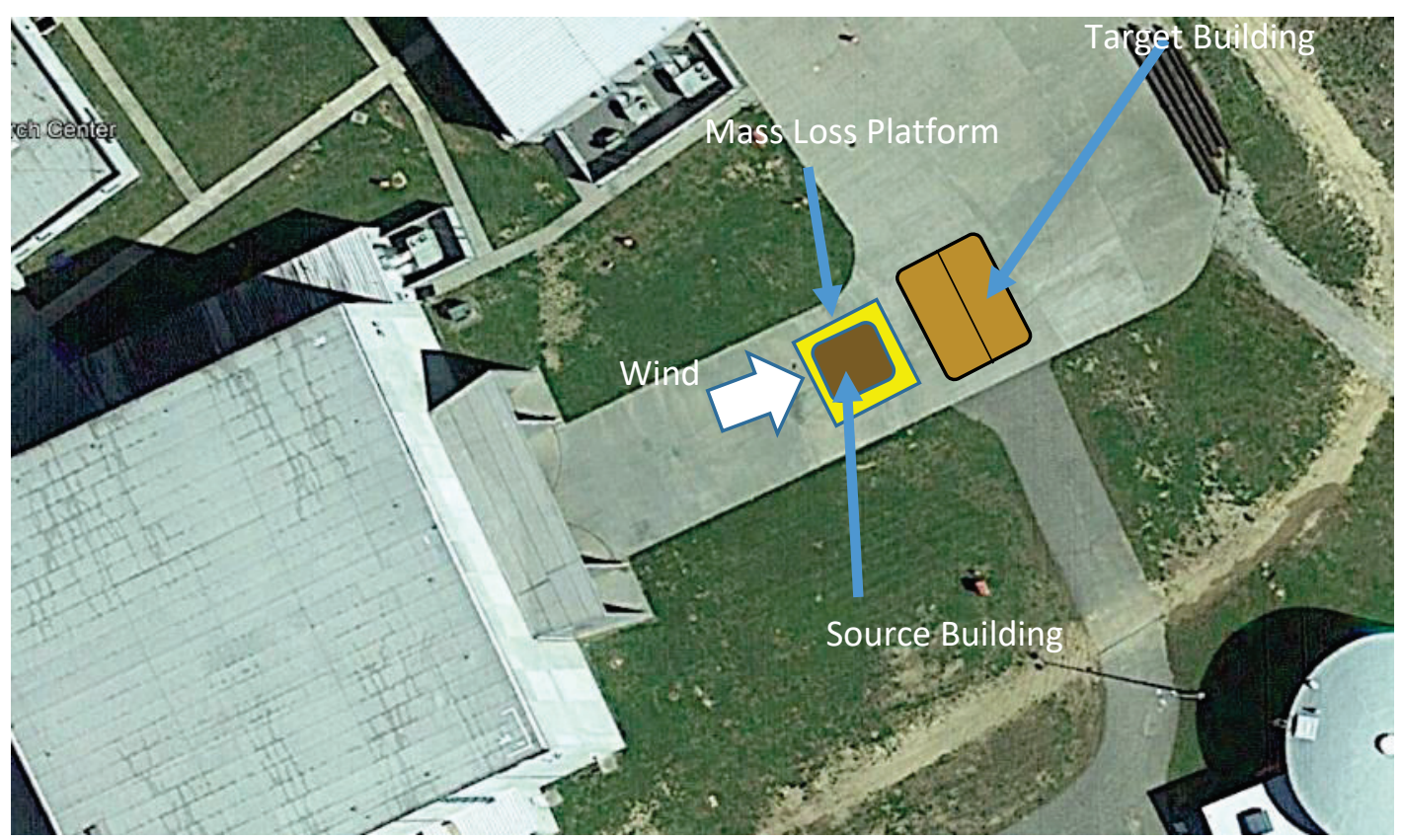

Figure 17: Aerial view of test facility (April 2018) and locations of target and source buildings. Positions and orientations are approximate. Imagery: Google, Landsat/Copernicus. Overlays: NIST. 


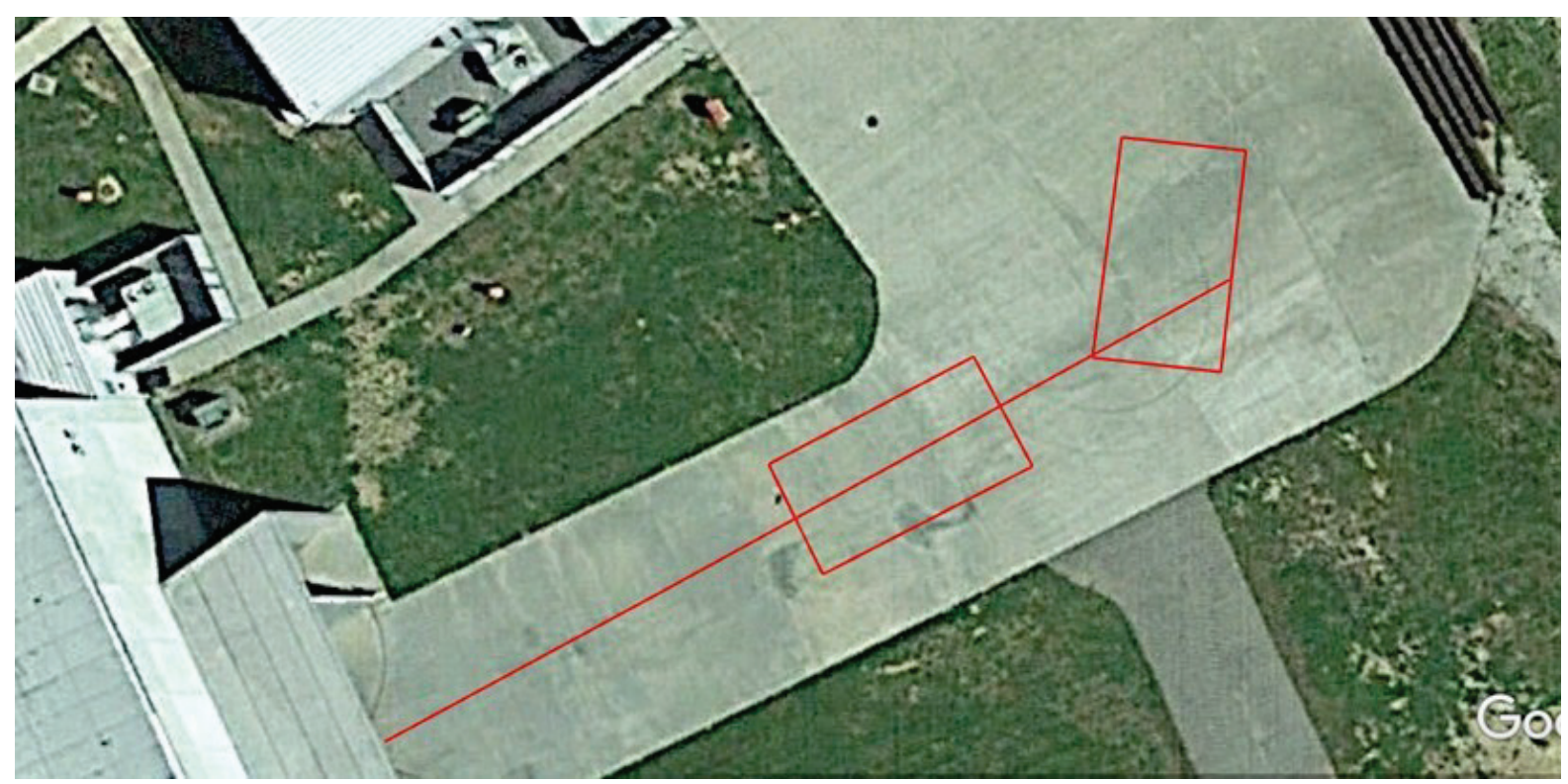

Figure 18: Aerial view of IBHS test facility (April 2018), source building at $0^{\circ}$ and target building at $45^{\circ}$. Positions and orientations approximate. Imagery: Google, Landsat/ Copernicus. Overlays: NIST.

\subsection{Ignition system}

The ignition system is the same as the one described in Section 4.2.3.

\subsection{Instrumentation and data collection system}

a. Heat flux measurements all around the source structure (all four sides and at different elevations) and with distance to match Chapter 7A spacing for non-hardened buildings.

b. Mass loss measurements: Load cells with frame and platform under the source structure.

c. Videos (Visible).

d. Firebrand collection using water pans.

e. Data collection system sampling frequency.

\subsection{Test matrix}

Shed burn experiments at IBHS are divided in two parts:

1. Shed burn experiments for mass loss measurements (with weighing platform and no wind).

2. Shed burn experiments for measurement of structure separation distance (SSD) (with wind and no weighing platform). 
The test matrix (Table 10 through Table 13) may be modified, in consultation with CAL FIRE, based on experimental results. Specification of sheds to be used in IBHS shed burn experiments are provided in Table 13. More details on structure orientations, SSD, and instrumentation are provided in Appendix D. Structure orientations with respect to the wind direction can have significant impact on SSD. Vulnerabilities of the structure corners are shown in Appendix E.

\subsubsection{Shed burn experiments to determine mass loss (no wind)}

Experiments listed in Table 10 will be used to collect mass loss rates from primarily large and very large sheds. A target structure (Figure 19) with a wall and roof will be used in mass loss experiments. These experiments will be used to develop the target structure instrumentation design for experiments listed in Table 12.

Table 10: Phase 1B small secondary structure exposure source (shed) burn experiments at IBHS (without target structure)

\begin{tabular}{|l|l|l|c|c|c|}
\hline $\begin{array}{l}\text { Serial } \\
\text { Number }\end{array}$ & Test ID & Source Construction & $\begin{array}{c}\text { Source } \\
\text { Size }\end{array}$ & $\begin{array}{c}\text { Fuel } \\
\text { Loading }\end{array}$ & Wind \\
\cline { 1 - 5 } 1 & 1B-WMh0 & Wood & M & High & No \\
\hline 2 & 1B-SLh0 & \multirow{2}{*}{ Steel } & L & High & No \\
\cline { 2 - 5 } 3 & 1B-SVLh0 & & VL & High & No \\
\hline 4 & 1B-PLh0 & Plastic/Composite & L & High & No \\
\hline 5 & 1B-WVLh0 & Wood Chapter 7A* & VL & High & No \\
\hline
\end{tabular}

* Construction compliant with Chapter $7 A$ if available.

\section{Building platform}

The construction of the mass loss platform is similar to the one used during the NIST NFRL shed burn experiments (see Section 4.2.2). The nominal dimensions of the building platform will be $3.65 \mathrm{~m} \times 10.97 \mathrm{~m}(24 \mathrm{ft} \times 36 \mathrm{ft})$ to accommodate a Very Large shed $(3.65 \mathrm{~m} \times 7.31 \mathrm{~m}$ $(12 \mathrm{ft} \times 24 \mathrm{ft}))$. Figure 19 shows the experimental set up for mass loss measurements during shed burn experiments at IBHS. 


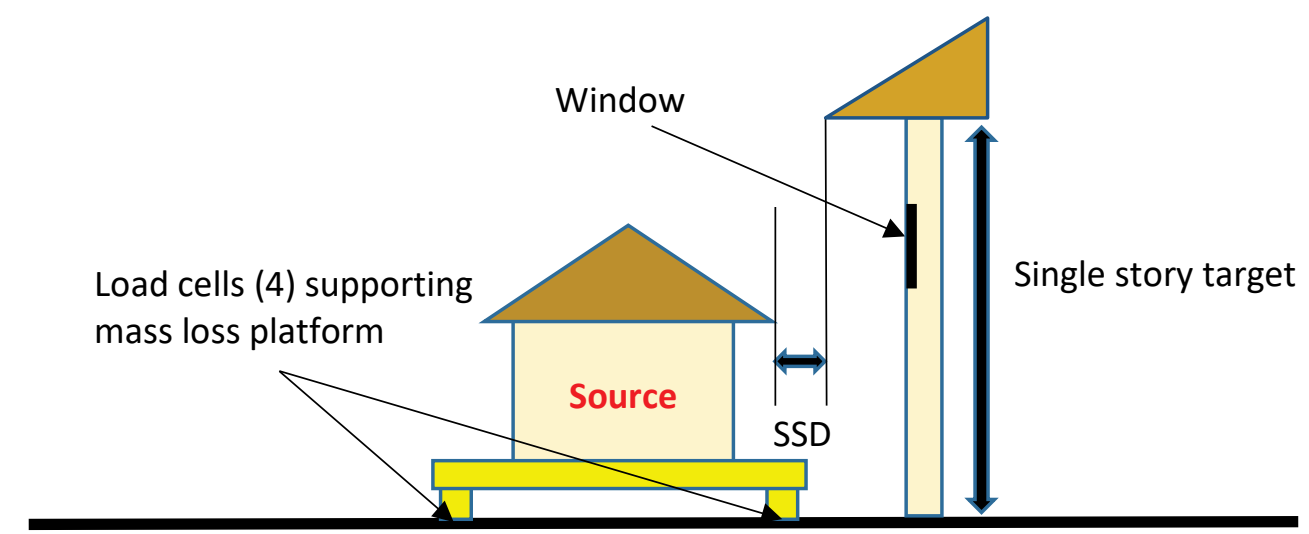

Figure 19: Load cells and mass loss platform for IBHS shed burn experiments without wind (figure not to scale).

\section{Targets}

a. Target wall/window assemblies with double pane windows facing heat flux and time exposures that result in window cracking, paint blistering and vinyl deforming/melting.

b. Instrumented targets placed at different distances.

\subsubsection{Shed burn experiments to measure structure separation distance (with wind)}

Three experiments will be conducted to observe plume lean on the target structure under varying wind speeds. No mass loss measurements will be undertaken during these shed burn experiments with wind. The information gathered during these experiments will be used to design the experiments in Table 11. Various shed and target orientations and SSD for IBHS shed burn experiments with wind are shown in Appendix D.

\section{Wind system}

Wind will be generated by the IBHS test cell for the experiments conducted outside the test cell. The source and the target structure placement will be based on the results of the cold flow experiments (IBHS) and model simulations (USFS) conducted during Phase 1A.

\section{Target structure}

The structure design will be finalized based on the cold flow experiments and modeling of the flow outside the IBHS test cell. The target structure orientation and placement of shed (source) will dictate the construction and the design features. To expedite turnover between experiments and limit overall costs, one of the side(s) of the structure facing the fire (source) will be constructed to Chapter 7A construction requirements. The remainder of the structure can be a shell to provide the necessary flow obstruction. Such a target (1.5-story) structure will serve two purposes: 
a. to assess the performance of Chapter 7A compliant building performance when exposed to different radiative and convective fluxes from a burning shed (source structure).

b. to provide a realistic flow obstruction as compared to just a building facade.

Table 11: Phase 1B small secondary structure exposure source (shed) burn experiments at IBHS (with wind)

\begin{tabular}{|l|l|l|l|}
\hline $\begin{array}{l}\text { Exposure } \\
\text { Source }\end{array}$ & $\begin{array}{l}\text { Source } \\
\text { Construction }\end{array}$ & SSD* (ft) & Wind (mi/h) \\
\hline $\begin{array}{l}\text { Small } \\
\text { Secondary } \\
\text { Structure }\end{array}$ & Wood $* *^{*}$ & TBD & $\begin{array}{l}\text { Baseline wind speed needs to be } \\
\text { determined }\end{array}$ \\
\cline { 2 - 4 } & Steel** & TBD & $\begin{array}{l}\text { Second wind speed needs to be } \\
\text { determined }\end{array}$ \\
\cline { 2 - 4 } & Plastic/Composite** & TBD & $\begin{array}{l}\text { Third wind speed needs to be } \\
\text { determined }\end{array}$ \\
\hline $\begin{array}{l}\text { Total } \\
\text { experiments }\end{array}$ & $(3 \times 2)+2$ wind +2 replicates +2 heat flux measurements $=12$ experiments \\
\hline
\end{tabular}

* Structure separation distances are preliminary estimates to be finalized after Phase $1 A$ experiments.

** Source building size, fuel loading, and ignition scenario will be determined from Phase 1A NIST NFRL experiments, IBHS no-wind experiments, and modeling results. 


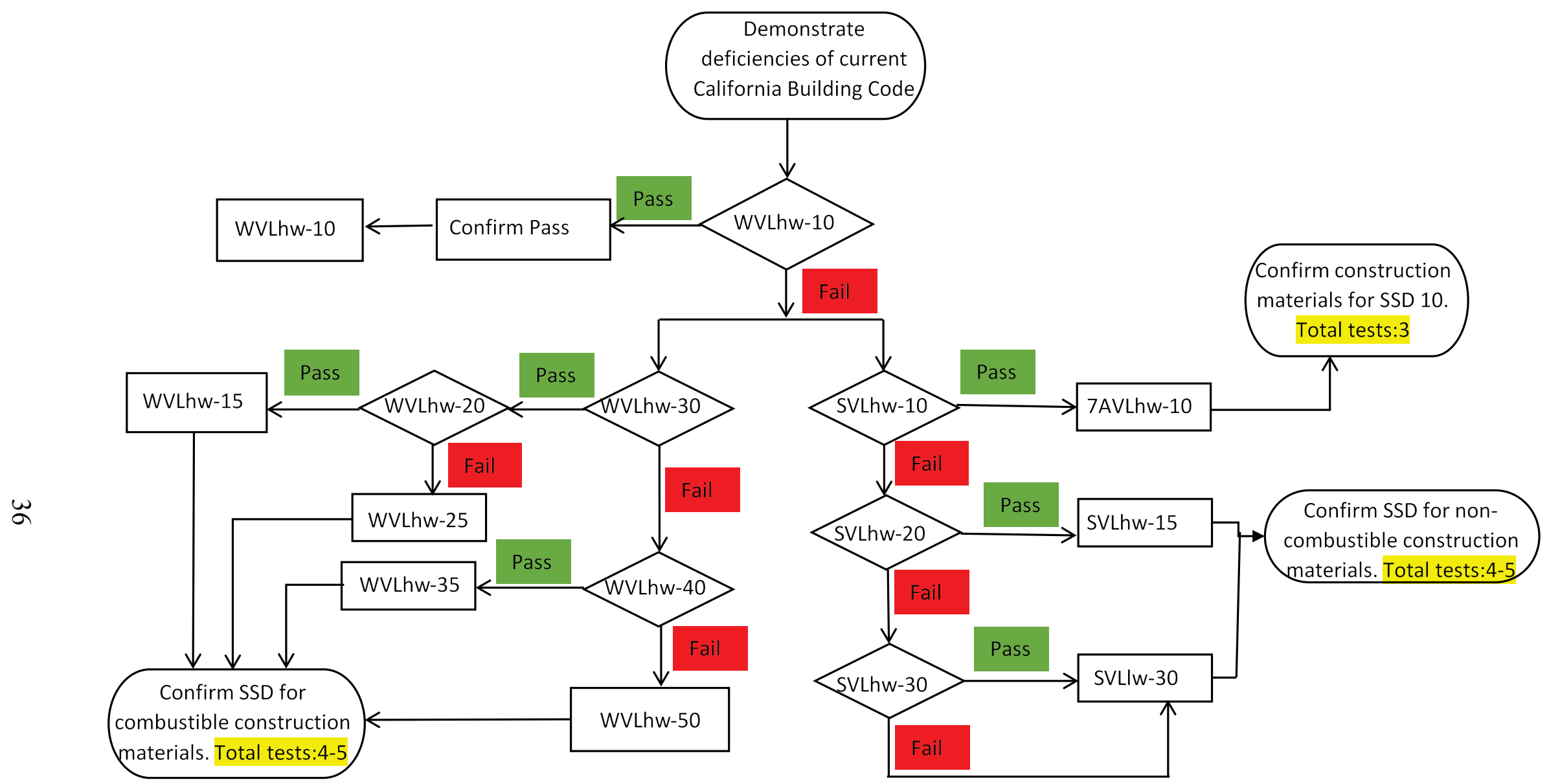

Figure 20: Conditional flowchart for IBHS test matrix. 
Table 12: Phase 1B preliminary test matrix, small secondary structure exposure source (shed) burn experiments at IBHS (with wind)

\begin{tabular}{|c|c|c|c|c|c|c|c|}
\hline $\begin{array}{c}\text { Serial } \\
\text { Number }\end{array}$ & Test ID & $\begin{array}{c}\text { Source } \\
\text { Construction }\end{array}$ & Source Size & $\begin{array}{c}\text { Fuel } \\
\text { Loading }\end{array}$ & SSD, (ft) & Wind, (mi/h) & Technical Justification \\
\hline 1 & 1B-WVLhw-10 & Wood & $\begin{array}{c}\mathrm{VL} \\
(12 \mathrm{ft} \times 24 \mathrm{ft})\end{array}$ & High & 10 & Baseline & $\begin{array}{l}\text { Current exposure to neighboring } \\
\text { residence (both shed and residence non- } \\
\text { sprinklered) }\end{array}$ \\
\hline 2 & 1B-WVLhw-30 & Wood & $\begin{array}{c}\mathrm{VL} \\
(12 \mathrm{ft} \times 24 \mathrm{ft})\end{array}$ & High & 30 & Baseline & $\begin{array}{l}\text { Determine if } 30 \mathrm{ft} \text { SSD results in } \\
\text { residence ignition - Use experiment to } \\
\text { direct next SSD experiment }\end{array}$ \\
\hline 3 & 1B-WVLhw-20/40 & Wood & $\begin{array}{c}\mathrm{VL} \\
(12 \mathrm{ft} \times 24 \mathrm{ft})\end{array}$ & High & 20 or 40 & Baseline & $\begin{array}{l}\text { Using pass-fail from above test revised } \\
\text { SSD }\end{array}$ \\
\hline 4 & 1B-WVLhw-TBD & Wood & $\begin{array}{c}\mathrm{VL} \\
(12 \mathrm{ft} \times 24 \mathrm{ft})\end{array}$ & High & $\begin{array}{l}15,25,35 \\
\quad \text { or } 50\end{array}$ & Baseline & $\begin{array}{l}\text { Using pass-fail from above test revised } \\
\text { SSD }\end{array}$ \\
\hline 5 & 1B-MVLhw-10 & Steel & $\begin{array}{c}\mathrm{VL} \\
(12 \mathrm{ft} \times 24 \mathrm{ft})\end{array}$ & High & $10^{*}$ & Baseline & $\begin{array}{l}\text { Same as Test } 1 \text { for Steel (lowest } \\
\text { exposure construction). If } 5 \text { fails, no } \\
\text { need to do } 6 .\end{array}$ \\
\hline 6 & 1B-7AVLhw-10 & Chapter 7A & $\begin{array}{c}\mathrm{VL} \\
(12 \mathrm{ft} \times 24 \mathrm{ft})\end{array}$ & High & 10 & Baseline & Same as Test 1 for Chapter 7A \\
\hline 7 & 1B-SVLhw-20 & Steel & $\begin{array}{c}\mathrm{VL} \\
(12 \mathrm{ft} \times 24 \mathrm{ft})\end{array}$ & High & 20 & Baseline & Determine SSD for Steel \\
\hline 8 & 1B-SVLhw-15/25 & Steel & $\begin{array}{c}\mathrm{VL} \\
(12 \mathrm{ft} \times 24 \mathrm{ft}) \\
\end{array}$ & High & 15 or 30 & Baseline & Determine SSD for Steel \\
\hline 9 & 1B-SVLhw-TBD-R1 & Steel & $\begin{array}{c}\mathrm{VL} \\
(12 \mathrm{ft} \times 24 \mathrm{ft}) \\
\end{array}$ & High & Pass SSD & Baseline & Repeat of Pass SSD \\
\hline 10 & 1B-WVLhw-TBD-R2 & Wood & $\begin{array}{c}\mathrm{VL} \\
(12 \mathrm{ft} \times 24 \mathrm{ft})\end{array}$ & High & Fail SSD & Baseline & Repeat of Fail SSD \\
\hline 11 & 1B-WVL1-TBD & Wood & $\begin{array}{c}\mathrm{VL} \\
(12 \mathrm{ft} \times 24 \mathrm{ft})\end{array}$ & Low & $\begin{array}{l}\text { Fail SSD } \\
\text { (TBD } \\
\text { from Test } \\
1 \text { to } 4) * *\end{array}$ & Baseline & Effect of fuel loading on SSD \\
\hline 12 & 1B-MVLlw-TBD & Steel & $\begin{array}{c}\mathrm{VL} \\
(12 \mathrm{ft} \times 24 \mathrm{ft})\end{array}$ & Low & TBD & Baseline & $\begin{array}{l}\text { Determine SSD for Steel or use as a } \\
\text { Steel replicate }\end{array}$ \\
\hline
\end{tabular}

* May have Chapter 7 A compliant walls based on data from NIST burns 
Table 13: Specifications for medium, large and very large sheds to be tested at IBHS test facility $(1 \mathrm{ft}=0.0305 \mathrm{~m}, 1 \mathrm{lb}=0.453 \mathrm{~kg})$.

\begin{tabular}{|c|c|c|c|c|l|}
\hline $\begin{array}{c}\text { Wood } \\
\text { Sheds }\end{array}$ & Examples & $\begin{array}{c}\text { Size } \\
\mathbf{D} \times \mathbf{W} \times \mathbf{H}, \mathbf{f t}\end{array}$ & $\begin{array}{c}\text { Door } \\
\mathbf{W} \times \mathbf{H}, \mathbf{f t}\end{array}$ & Weight, lb & $\begin{array}{l}\text { Notes } \\
\text { Medium } \\
8 \mathrm{ft} \times 8 \mathrm{ft}\end{array}$ \\
\hline
\end{tabular}


Table 13 (continued)

\begin{tabular}{|c|c|c|c|c|c|c|}
\hline $\begin{array}{l}\text { Steel } \\
\text { Sheds }\end{array}$ & Examples & $\begin{array}{c}\text { Size } \\
\mathrm{D} \times \mathbf{W} \times \mathbf{H}, \mathrm{ft}\end{array}$ & $\begin{array}{c}\text { Capacity, } \\
\mathrm{ft}^{3}\end{array}$ & $\begin{array}{c}\text { Door } \\
\mathbf{W} \times \mathbf{H}, \mathbf{f t}\end{array}$ & $\begin{array}{l}\text { Weight, } \\
\text { lb }\end{array}$ & Notes \\
\hline $\begin{array}{l}\text { Medium } \\
7 \mathrm{ft} \times 8 \mathrm{ft}\end{array}$ & Link & $7 \times 8 \times 7$ & 392 & $4.2 \times 5.8$ & 241 & $\begin{array}{l}\text { Double door } \\
\text { Roof material: Steel } \\
\text { Construction material: Galvanized steel } \\
\text { Floor: not included } \\
\text { Vents: } 2 \text { gable vents }\end{array}$ \\
\hline $\begin{array}{c}\text { Large } \\
10 \mathrm{ft} \times 12 \mathrm{ft}\end{array}$ & Link & $10 \times 12 \times 6.5$ & 780 & $4.6 \times 5.4$ & 288 & $\begin{array}{l}\text { Double door } \\
\text { Roof material: Steel } \\
\text { Construction material: Galvanized steel } \\
\text { Floor: not included } \\
\text { Vents: None }\end{array}$ \\
\hline $\begin{array}{c}\text { V Large } \\
12 \mathrm{ft} \times 24 \mathrm{ft}\end{array}$ & Link & $16 \times 10 \times 8.6$ & 1376 & $3.1 \times 6.9$ & 1675 & $\begin{array}{l}\text { Single door } \\
\text { Roof material: Steel } \\
\text { Construction material: Galvanized steel } \\
\text { Floor: not included } \\
\text { Window }\end{array}$ \\
\hline
\end{tabular}




\section{Table 13 (continued)}

\begin{tabular}{|c|c|c|c|c|c|c|}
\hline $\begin{array}{l}\text { Plastic } \\
\text { Sheds }\end{array}$ & Examples & $\begin{array}{c}\text { Size } \\
\mathbf{D} \times \mathbf{W} \times \mathbf{H}, \mathbf{f t}\end{array}$ & $\begin{array}{c}\text { Capacity, } \\
\mathrm{ft}^{\mathbf{3}}\end{array}$ & $\begin{array}{c}\text { Door } \\
\mathbf{W} \times \mathbf{H}, \mathbf{f t}\end{array}$ & $\begin{array}{c}\text { Weight, } \\
\text { lb }\end{array}$ & Notes \\
\hline $\begin{array}{l}\text { Medium } \\
8 \mathrm{ft} \times 8 \mathrm{ft}\end{array}$ & Link & $8 \times 8 \times 7.6$ & 486 & $4.2 \times 5.8$ & 128 & $\begin{array}{l}\text { Double doors } \\
\text { Roof material: Plastic } \\
\text { Construction material: Polycarbonate } \\
\text { Floor: No } \\
\text { Vents: } 4 \text { ( } 2 \text { in front and } 2 \text { at the back) }\end{array}$ \\
\hline $\begin{array}{c}\text { Large } \\
10 \mathrm{ft} \times 12 \mathrm{ft}\end{array}$ & $\underline{\text { Link }}$ & $11 \times 11 \times 10$ & 1210 & $4.8 \times 6.4$ & 869 & $\begin{array}{l}\text { Double doors } \\
\text { Roof material: Plastic } \\
\text { Construction material: high-density } \\
\text { polyethylene (HDPE) panels } \\
\text { Floor: yes } \\
\text { Vents: } 1 \\
\text { Windows: } 2\end{array}$ \\
\hline $\begin{array}{c}\text { V Large } \\
12 \mathrm{ft} \times 24 \mathrm{ft}\end{array}$ & Link & $11 \times 21 \times 8$ & 1848 & $4.8 \times 5.8$ & 425 & $\begin{array}{l}\text { Double doors } \\
\text { Roof material: Plastic, Polycarbonate } \\
\text { Construction material: Polycarbonate } \\
\text { panels } \\
\text { Floor: No } \\
\text { Vents: } 2 \\
\text { Windows: } 0\end{array}$ \\
\hline
\end{tabular}




\subsection{Experimental series operations}

The sequence of operations for executing the Phase 1B IBHS shed burn experiments is as follows:

1. Fabricating the mass loss platform.

2. Installing the source structure.

3. Installing the target structure. ${ }^{4}$

4. Placing instrumentation.

5. Conducting burn experiment.

6. Reviewing the experimental area.

7. Setting up the next experiment.

\subsection{Experimental outcomes}

The expected outcomes from Phase 1B IBHS shed burn experiments are listed below.
a. Identify source size, construction, and fuel loading for Phase 2 experiments.
b. Identify ignition type for Phase 2 .
c. Identify instrumentation layout and types for Phase 2 .
d. Identify the orientation of opening(s) for source buildings for Phase 2 .
e. Identify model inputs.
f. Validate and verify model simulations.

\footnotetext{
${ }^{4}$ Only part of the building may need to be replaced. See section 5.5.2.
} 


\section{Modeling of Experiment Design and Experiments}

\subsection{Model development to estimate safe separation distance}

The main goal of this component of the project is to develop methodology for comparing experiments and modeling predictions, including uncertainties. This modeling component has multiple objectives. The following objectives are not limited to Phase 1 but will also extend to Phases 2 and 3. Additional Phase 2 and 3 goals are listed in Section 6.7.

SSE Modeling Objectives:

a) Validation and Verification of NIST Fire Dynamics Simulator (FDS) for specific outdoor experiments.

This goal will leverage experiments at NIST and IBHS to assess FDS performance in predicting wind around obstructions and heat fluxes in both wind and no wind scenarios.

b) Design of structure separation experiments.

FDS will be used to aid the design of the NIST indoor and outdoor experiments. The placement of the Target under the NIST $9 \mathrm{~m} \times 12 \mathrm{~m}$ Calorimeter will be determined with input from simulations. Additionally, FDS will be used to determine the placement of the source (Shed) door opening with respect to the Target for the IBHS experiments.

c) Design of test methods for codes and standards.

FDS will be used to assess the performance of existing test methods and support the development of laboratory scale tests that reliably represent specific WUI exposures. Emphasis will be placed on creating radiative and convective exposures representative of those from burning adjacent structures.

d) Evaluation of safety factors for scenarios where it is difficult to perform experiments. The experiments outlined in all three Phases of this SSE research effort will be executed on flat terrain. FDS will be used to quantify the effects of slope, with varying winds, as well as the potential effects of different target designs on the resulting local radiative and convective exposures.

Modeling to estimate the safe separation distance between a real full scale fire source (burning shed, fence etc.) and a target (primary structure, walls, eaves, windows etc.) is a complex task, and we plan to systematically and gradually increase the complexity of the modeling simulations starting from very simple configurations. Table 14 below roughly outlines the major modeling tasks as well as the primary technical issues. Detailed reports will be published during the course of this project to describe the progress on the various tasks in more detail. 
Table 14. Major modeling tasks and the associated primary technical issues during Phase 1 of the Structure Separation Experiments (SSE)

\begin{tabular}{|c|l|l|}
\hline $\begin{array}{c}\text { Serial } \\
\text { Number }\end{array}$ & \multicolumn{1}{|c|}{ Tasks } & \multicolumn{1}{c|}{ Primary Technical Issues } \\
\hline 1 & $\begin{array}{l}\text { Radiative / Convective Flux } \\
\text { from a Burner in Zero Wind } \\
\text { Condition }\end{array}$ & $\begin{array}{l}\text { Validation studies on flame height, vertical } \\
\text { plume center-line velocities, and temperature } \\
\text { profiles. Comparison with literature values }\end{array}$ \\
\hline 2 & $\begin{array}{l}\text { Radiative / Convective Flux } \\
\text { from a Burner in Ambient } \\
\text { Wind }\end{array}$ & $\begin{array}{l}\text { Validation studies on flame deflection. } \\
\text { Comparison with Heskestad correlations. } \\
\text { Dilution of the fire plume due to the ambient } \\
\text { wind and flame stretch. }\end{array}$ \\
\hline 3 & $\begin{array}{l}\text { Effect of Target on Plume } \\
\text { Dynamics }\end{array}$ & $\begin{array}{l}\text { Nature of the stagnation flow and its effect on } \\
\text { plume dynamics. Modeling considerations for } \\
\text { flows around complex geometries with heat } \\
\text { transfer. }\end{array}$ \\
\hline 4 & $\begin{array}{l}\text { Introduction of a real fire } \\
\text { source (shed, fence) in the } \\
\text { flow field) }\end{array}$ & $\begin{array}{l}\text { Disruption of the flow field, stagnation region. } \\
\text { Time dependent heat release rates. Failure of } \\
\text { windows and collapse of the roof/walls. }\end{array}$ \\
\hline 5 & $\begin{array}{l}\text { Simulations of realistic source } \\
\text { and target geometries }\end{array}$ & $\begin{array}{l}\text { Resolving the flow field around complex } \\
\text { geometries. Flame spread on multi-layer, in- } \\
\text { homogenous materials. Ignition of target } \\
\text { structure. }\end{array}$ \\
\hline 6 & $\begin{array}{l}\text { Simulation of full-scale } \\
\text { experiments conducted at } \\
\text { IBHS and NIST }\end{array}$ & $\begin{array}{l}\text { Modeling of flow field generated by the fans / } \\
\text { wind tunnels. Predicting safe separation } \\
\text { distance }\end{array}$ \\
\hline
\end{tabular}

\subsection{FDS Simulations of fire plume}

Preliminary FDS simulations of a fire plume from a $1 \mathrm{~m} \times 1 \mathrm{~m}$ propane gas burner with steady heat release rates have been performed. The burner was placed symmetrically in the center of a $6 \mathrm{~m} \times 6 \mathrm{~m} \times 15 \mathrm{~m}$ domain. Multiple meshes (12) were used with a constant cell size of $0.1 \mathrm{~m}(10 \mathrm{~cm})$ to simulate the fire plume over a period of 30 seconds. The simulations assumed a radiative fraction of 0.22 , soot yield of 0.024 and a $\mathrm{CO}$ yield of 0.005 . Heat release rates were varied from $1 \mathrm{MW}$ to $16 \mathrm{MW}$. 


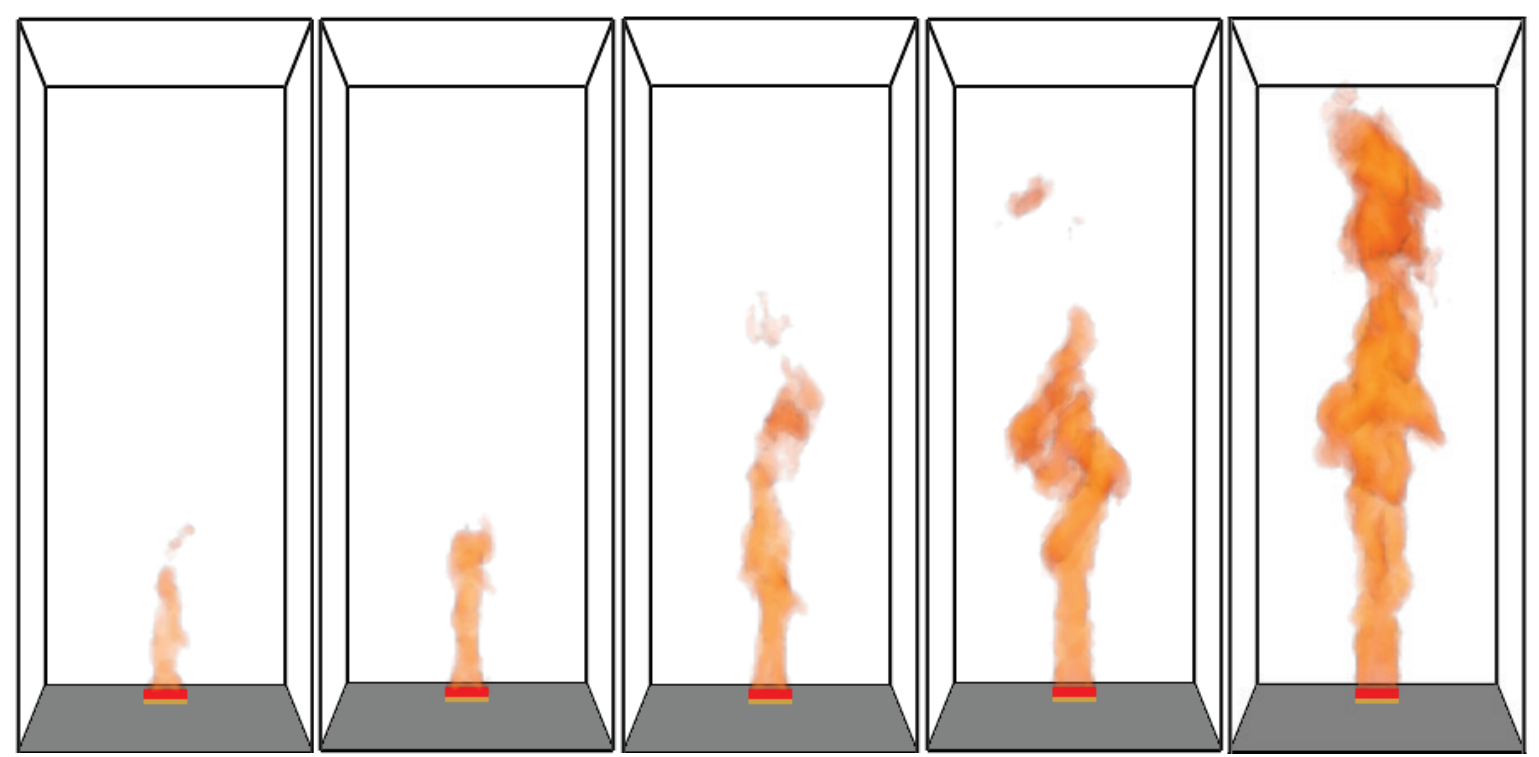

Figure 21: Instantaneous temperature iso-surface plots for heat release rates of $(1,2,4,8$, and 16) MW from $1 \mathrm{~m} \times 1 \mathrm{~m}$ propane burner (with no ambient wind).

Figure 21 shows the instantaneous iso-surface contours of temperature above a $1 \mathrm{~m} \times 1 \mathrm{~m}$ propane burner without any ambient wind. Simulation results clearly show that the flame height increases as the burner heat release rate increases. As the heat release rate increases, the peak vertical plume velocity through the centerline of the plume also increases.

Introducing an ambient wind deflects (bends) the fire plume in the direction of the wind. Figure 22 shows Smokeview results of an FDS simulations for a $16 \mathrm{MW}$ burner placed in an ambient wind of $4 \mathrm{~m} / \mathrm{s}$. The deflection of the plume is dependent on the relative magnitude of the ambient wind speeds and the vertical velocity generated by the buoyant gases in the plume. For a given heat release rate, the plume deflects more, as the ambient wind increases in magnitude. On the contrary, for a given ambient wind, the plume deflection reduces as the burner heat release rate increases. Accurately predicting the deflection of the plume is critical for estimating the structure separation distance. Plume deflection can result in flames impinging directly on a potential target structure located at some horizontal distance away from the burner. Deflection of the plume also affects the radiative and convective heat flux profiles that in turn affect the structure separation distance. 


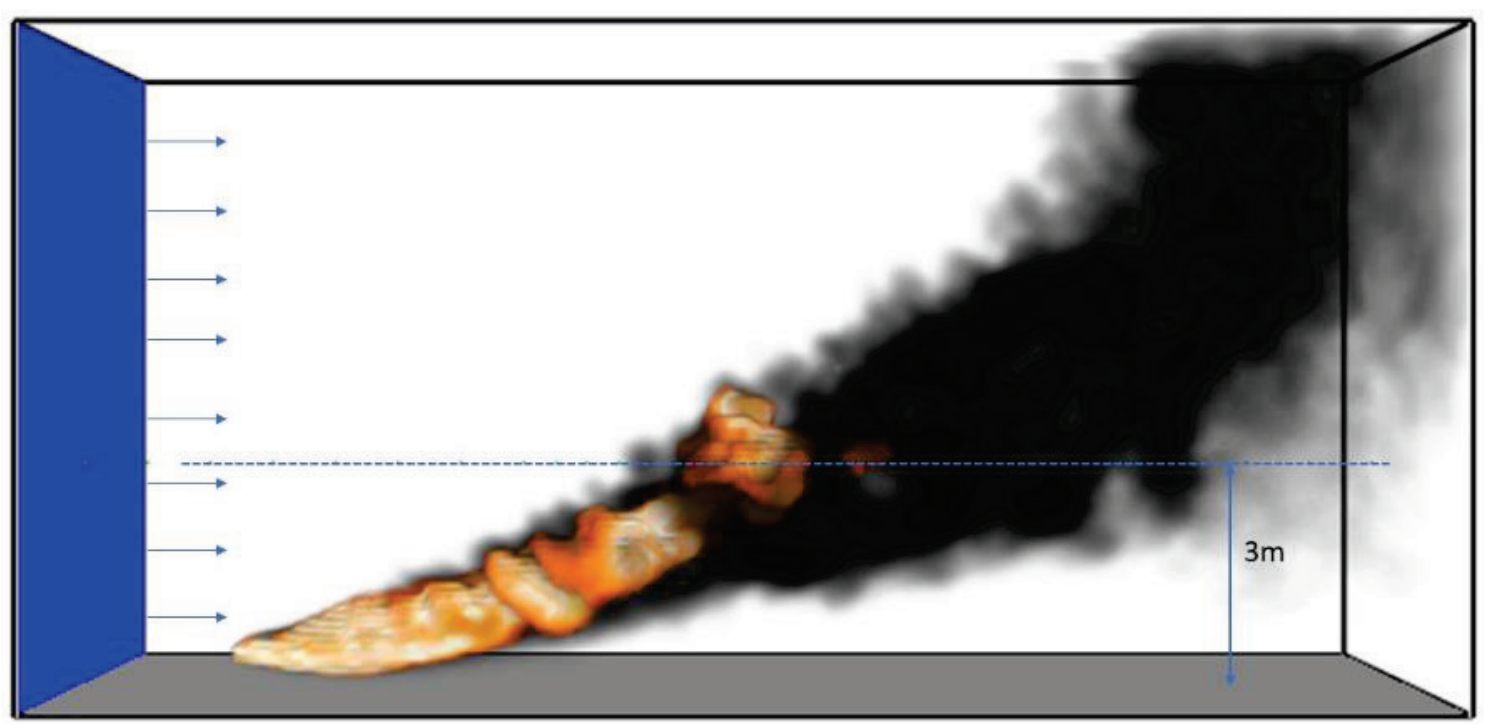

Figure 22: Numerical simulation of a $16 \mathrm{MW}$ burner placed in an ambient wind of $4 \mathrm{~m} / \mathrm{s}$. Results show the deflection of the fire plume.

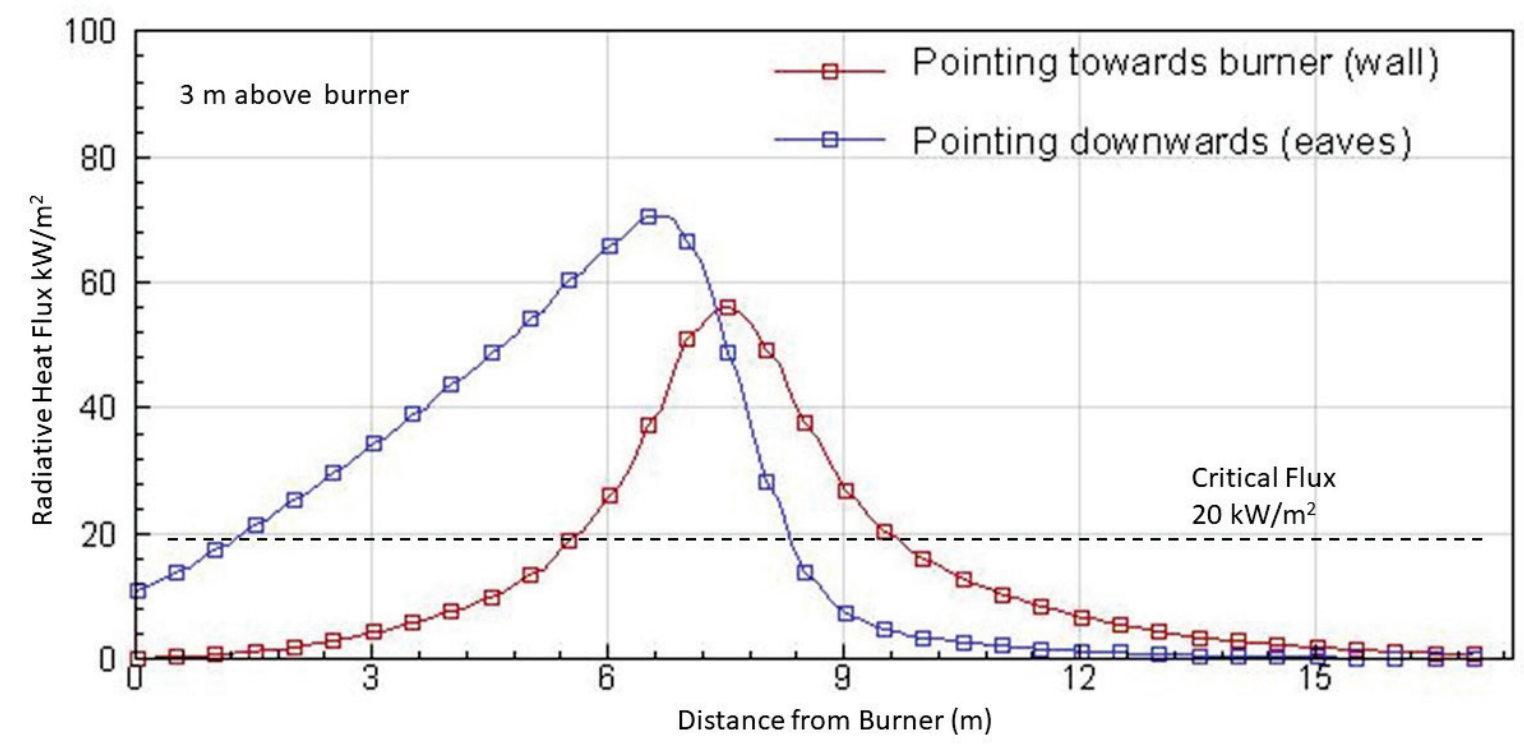

Figure 23: Radiative heat flux $\left(\mathrm{kW} / \mathrm{m}^{2}\right)$ for a gauge pointing towards burner (representing walls) and gauge pointing downwards (representing eaves).

As the fire plume tilts under the influence of the ambient wind, the incident radiative flux can be computed through the use of a virtual string of radiative flux gauges. These gauges can be used to measure the radiative flux at selected points in the simulation domain. Figure 23 shows the radiative heat flux, plotted as a function of distance from the burner. All results are shown for a height of $3 \mathrm{~m}$ above the burner, along the wind direction, approximating exposure to the eaves of a single-story target building. Both the radiative flux pointing towards the burner ( $-x$ direction, representing the flux to a wall) and pointing downwards $(-y$ 
direction, representing the flux to the eaves) have been shown. Results show that the radiative flux peaks at a certain distance from the burner. It should be noted that radiative flux above a critical value $\left(20 \mathrm{~kW} / \mathrm{m}^{2}\right.$, for example) can result in ignition (based on cone calorimetry experiments). While these simulations do not consider the geometric complexity of the source / target, expectation is that they can still provide us with valuable information on estimating the structure separation distance.

\subsection{Different wind orientations and structure layouts}

The cold flow measurements will dictate the range of different orientations in Phase 1A. Specifically, the wind field will determine the total usable area (outside of the IBHS test cell). Wind orientation with respect to the source and target structures are illustrated in the schematic in Figure 24 below. Modeling results will guide target placement with respect to the wind and the relative orientations of the source and target structures (Figure 25). The schematic illustrating Structure Separation Distance (SSD) is not to scale. The orientation and dimensions of the target structure will impact the design of the target face (i.e., the presence of windows and the design of roof/eave assembly).

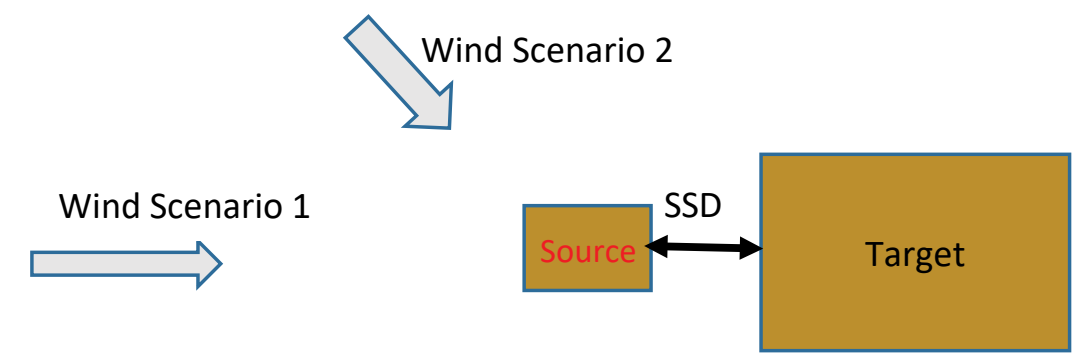

Figure 24: Different wind orientations and structure layouts (figure not to scale). 

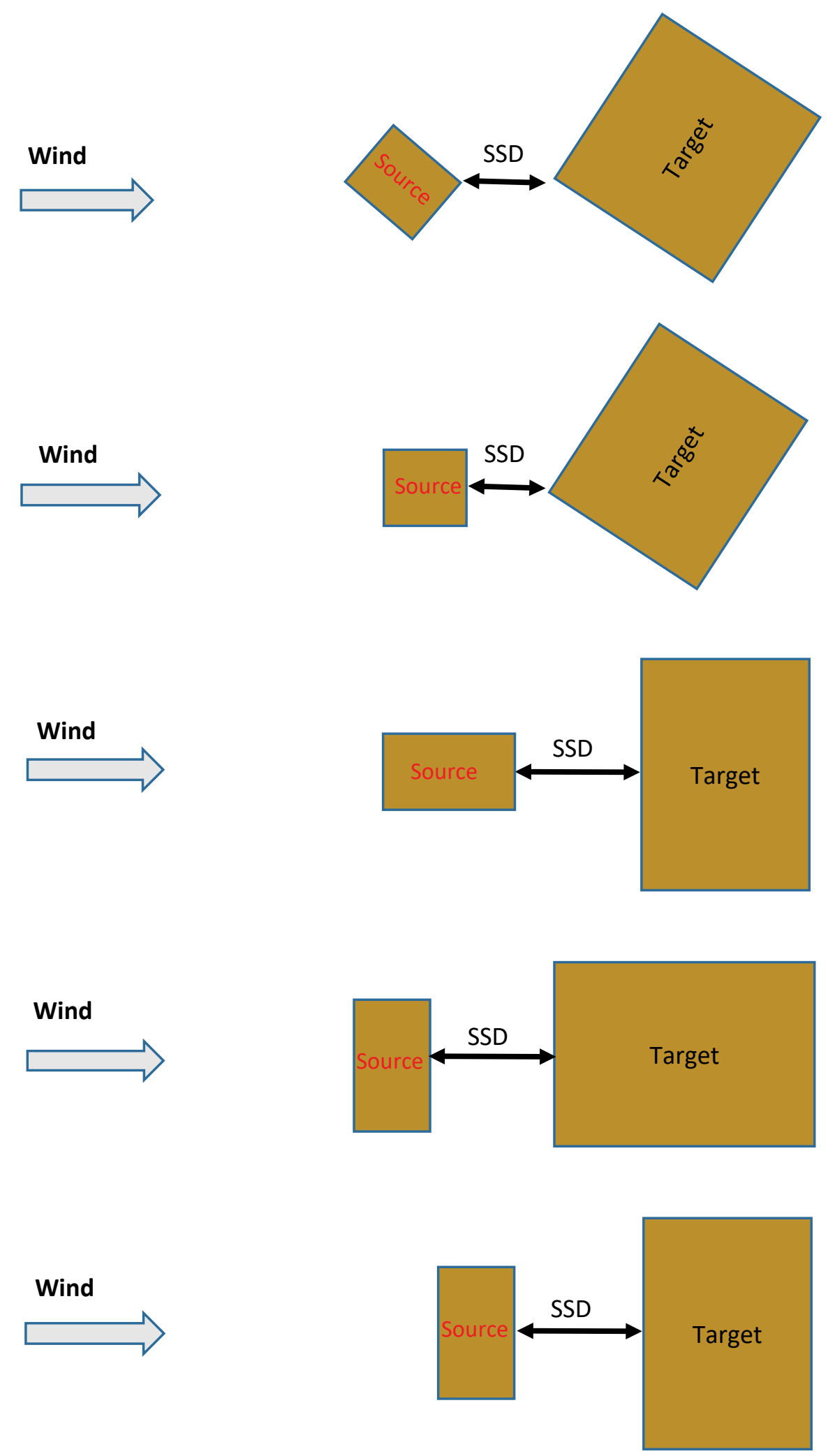

Figure 25: Different source and target structure layouts with respect to wind orientations. 
Modeling simulations will also explore the effect of source structure openings with respect to wind (Figure 26) on HRR. The model will likely use heat fluxes as surrogates for HRR.

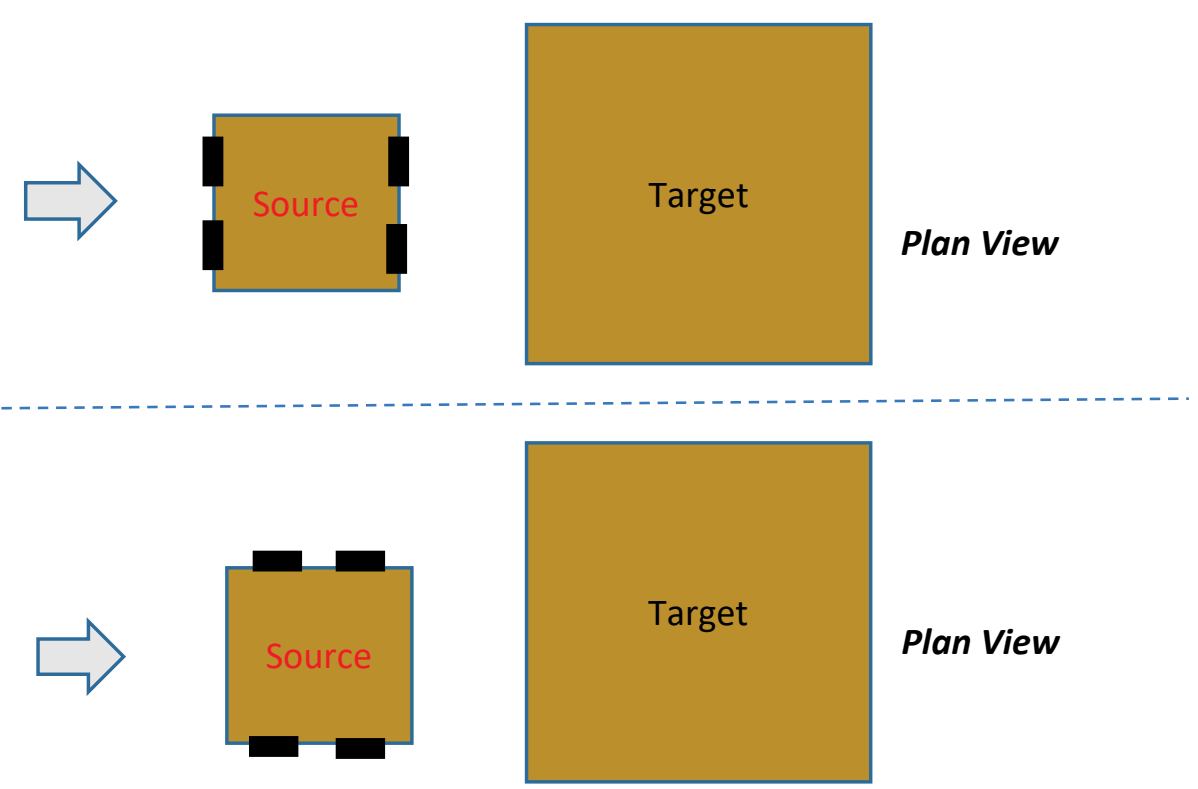

Figure 26: Orientation of source openings (figure not to scale). 


\subsection{Target dimensions including elevation (single story source)}

Like Section 6.3, the range of possible target building sizes will be dictated by the cold flow measurements in Phase 1A. Modeling will guide target building footprint and height (Figure 27 ) with respect to the wind. Schematics and SSD not to scale.
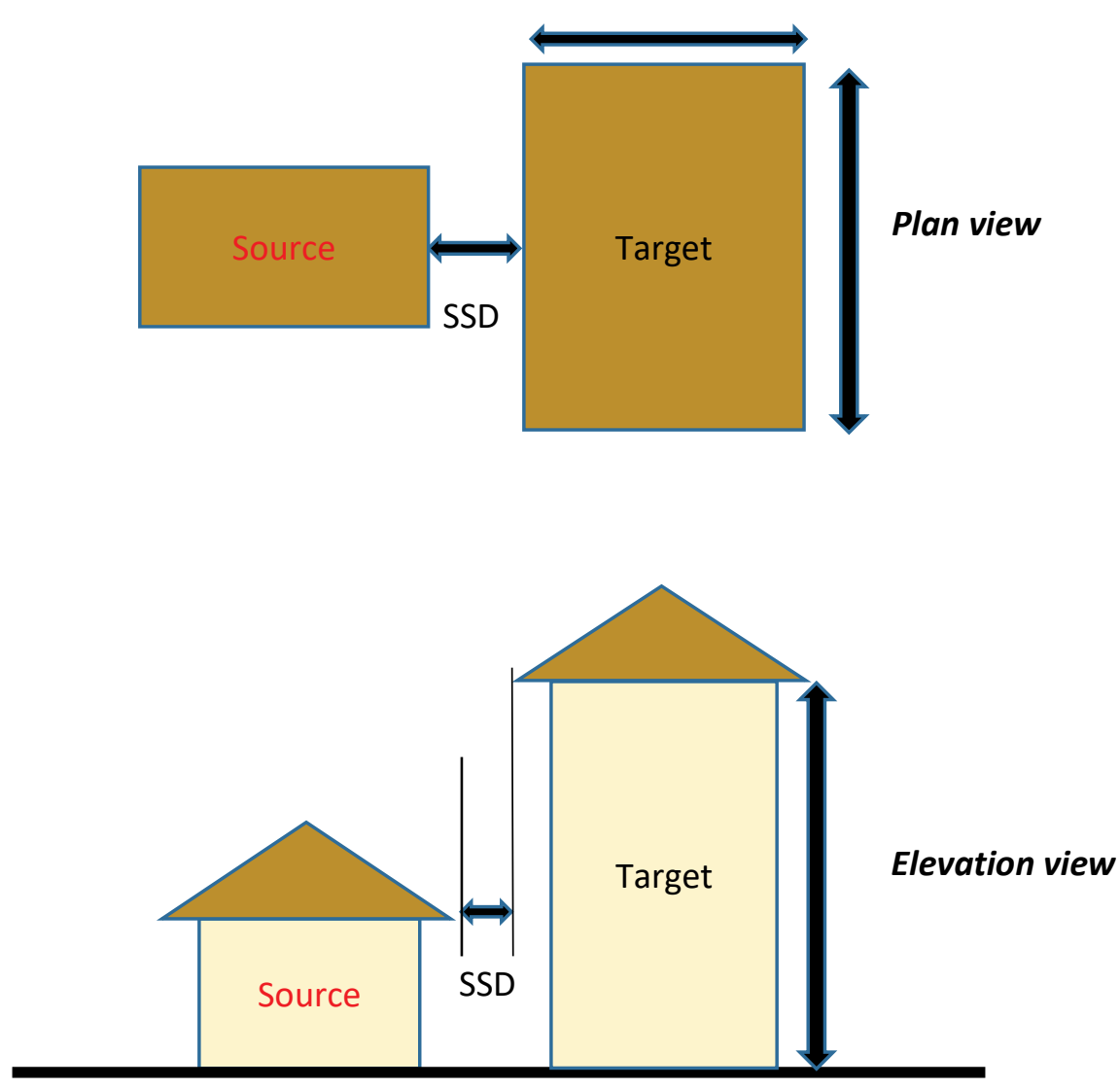

Figure 27: Target structure dimensions - including elevation (figure not to scale). 


\subsection{Effect of shed size on HRR}

The relationship between shed size and HRR will be explored based on NIST NFRL HRR/Mass Loss experiments. Modeling simulations will be used to investigate the potential impact of shed size and wind on HRR.

\subsection{Ignition scenarios}

Modeling and experimental results will guide the design of ignition scenarios. Single and multiple ignition scenarios will be evaluated for their effects on HRR. The effects of ignition location on the HRR curve will also be explored.

\subsection{Future Work - Phase 2 and 3}

During Phase 2 and 3 of the project, we will extend the methodology presented in the previous sections (for Phase 1) to realistic full-scale structures. Specifically, we will use the mass loss data, heat release rate (HRR), and structure separation distance (SSD) data from Phase 1 experiments and combine them with mass loss data from Phase 2 and 3 experiments to simulate full scale scenarios.

During Phase 2 and 3, we will also develop safety margins for slopes and target orientation. An additional task will be to assess if a laboratory scale test method for estimating structure separation distance can be developed and used to reliably predict SSDs.

Primary modeling tasks planned for Phase 2 and 3 are listed in Table 15 below. As progress is made on these tasks, separate reports will be made available describing the various tasks. 
Table 15. Major modeling tasks and the associated primary technical issues during Phase 2 and 3 of the Structure Separation Experiments (SSE)

\begin{tabular}{|c|l|l|}
\hline $\begin{array}{c}\text { Serial } \\
\text { Number }\end{array}$ & \multicolumn{1}{c|}{ Tasks } & \multicolumn{1}{c|}{ Primary Technical Issues } \\
\hline 1 & $\begin{array}{l}\text { Modeling of laboratory scale } \\
\text { experiments for codes and } \\
\text { standards }\end{array}$ & $\begin{array}{l}\text { Materials properties of target material. } \\
\text { Ignition temperature. }\end{array}$ \\
\hline 2 & $\begin{array}{l}\text { Modeling of real scale burns of } \\
\text { structures that will not be } \\
\text { tested at IBHS / NIST }\end{array}$ & $\begin{array}{l}\text { Incorporating mass loss and heat release data } \\
\text { from smaller scale tests }\end{array}$ \\
\hline 3 & $\begin{array}{l}\text { Safety factors incorporating } \\
\text { the effect of slope and } \\
\text { configuration }\end{array}$ & $\begin{array}{l}\text { Resolving flow fields with complex } \\
\text { geometries that do not confirm with the } \\
\text { cartesian mesh. }\end{array}$ \\
\hline
\end{tabular}




\section{CAL FIRE, NIST, IBHS, and USFS Teams Workflow}

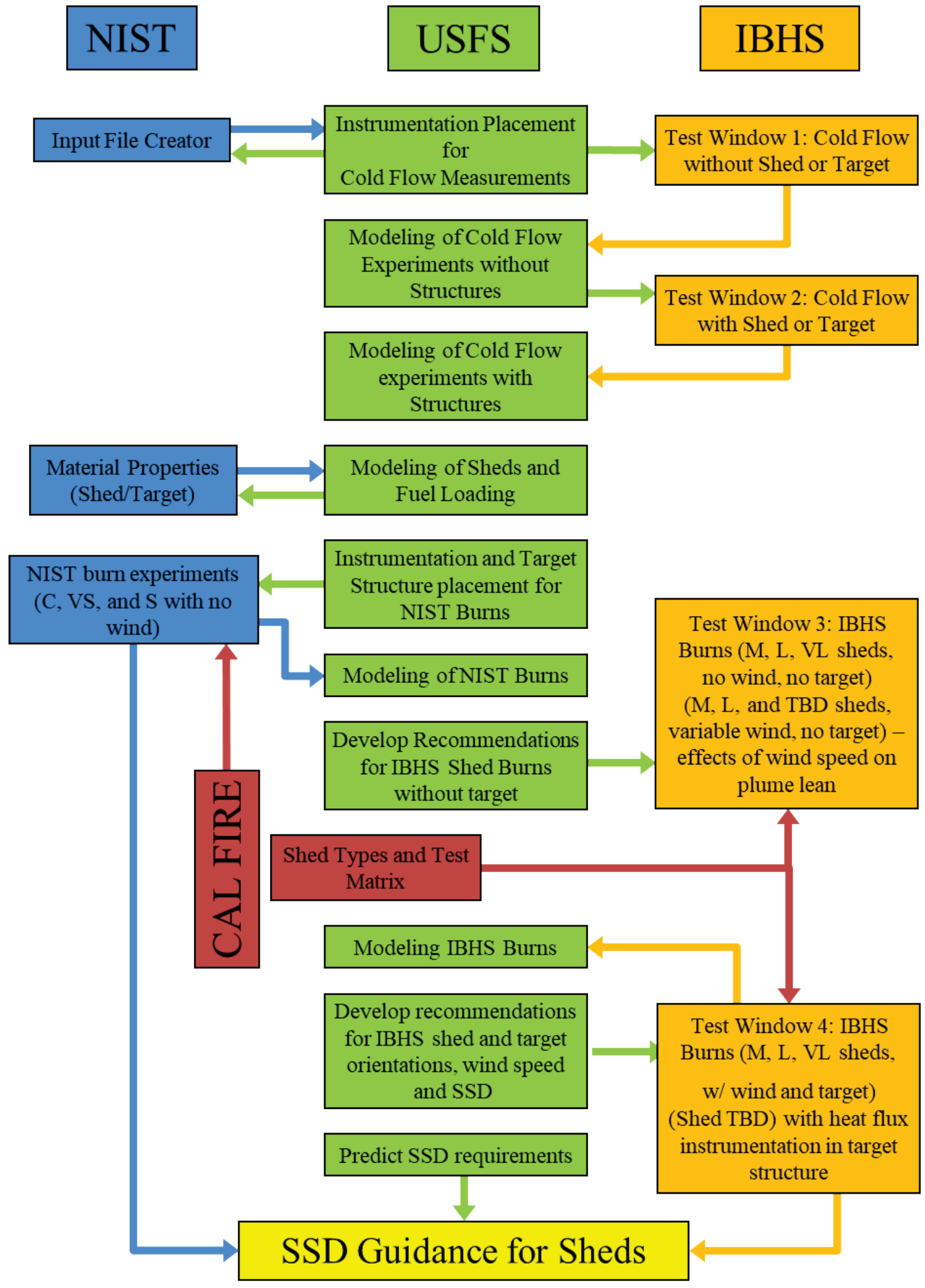




\section{Data Management}

This project addresses a complex technical problem leveraging skills and test facilities from multiple agencies/organizations including national research laboratories, building code officials, fire marshal officers who work with code enforcement, building industry association, and building insurance industry. The integrated research approach utilizing various test facilities, instrumentation, and modeling capabilities requires a robust database management system for seamless execution of the project. To facilitate easy availability of data to all project partners, an online repository will be created to store project description, detailed test plan, test data, instrumentation, calibration and verification reports, safety documents, images, and video clips. The data will be accessible to interested parties, besides project partners, for model validation. A preliminary data management and quality assurance plan is provided in Appendix F. 


\section{References}

[1] California Building Code-Chapter 7A-Materials and construction methods for exterior wildfire exposure. Available at https://up.codes/viewer/california/ca-building-code2016/chapter/7A/sfm-materials-and-construction-methods-for-exterior-wildfireexposure\#7A

[2] Bryant, R. and Bundy, M. The NIST 20 MW Calorimetry Measurement System for Large-Fire Research, NIST Technical Note (TN) 2077, 2019 https://doi.org/10.6028/NIST.TN.2077

[3] ASTM E 2886 - Standard Test Method for Evaluating the Ability of Exterior Vents to Resist the Entry of Embers and Direct Flame Impingement.

[4] ASTM E 2957 - Standard Test Method for Resistance to Wildfire Penetration of Eaves, Soffits and Other Projections.

[5] NFPA 286 - Standard Methods of Fire Tests for Evaluating Contribution of Wall and Ceiling Interior Finish to Room Fire Growth. 


\section{Appendix A. Fuel Loading}

Wood cribs of two different sizes will be used in this project. The general wood crib design is based on ANSI/UL711, ${ }^{5}$ and are consistent with sizes 1-A and 6-A in the standard. Crib 1-A (12 layers of 6 members with approximate dimensions of $38 \mathrm{~mm} \times 38 \mathrm{~mm} \times 500 \mathrm{~mm}$ ) will be placed within the source structures (closet, very small and small sheds) to simulate low and high fuel loadings in storage sheds. Approximate dimension of crib 1-A will be $500 \mathrm{~mm} \times 500 \mathrm{~mm} \times 456 \mathrm{~mm}$ for a given spacing of $54 \mathrm{~mm}$ between the two members.

Crib 6-A (23 layers of 10 members with approximate dimensions of $38 \mathrm{~mm} \times 38 \mathrm{~mm} \times$ $925 \mathrm{~mm}$ ) will be used for medium, large and very large sheds. The number of cribs will be varied to represent low and high fuel loadings. Approximate dimension of crib 6-A will be $925 \mathrm{~mm} \times 925 \mathrm{~mm} \times 874 \mathrm{~mm}$ for a given spacing of $60 \mathrm{~mm}$ between the two members.

The fuel loading specifications in terms of the number of wood cribs, total heat output, and total mass of woods cribs are provided in Table A-1. The total mass of fuel load is calculated based on pine wood with a density of $500 \mathrm{~kg} / \mathrm{m}^{3}$. The estimated heat output of the fuel loading is calculated from the basis that heat released from combustion of a unit mass of pyrolysis products for pine wood is approximately $19.2 \mathrm{MJ} / \mathrm{kg}$ and that the burning rate of the crib is controlled by the internal surface and not restricted by the porosity of the crib. ${ }^{6}$

\footnotetext{
${ }^{5}$ ANSI/UL 711, Standard for Rating and Fire Testing of Fire Extinguishers, 2013.

${ }^{6}$ Walton WD. Suppression of Wood Crib Fires with Sprinkler Sprays: Test Results. NBSIR 88-3696, January 1988.
} 
Table A-1: Fuel loading specifications for different source structures $(1 \mathrm{ft} .=0.0305 \mathrm{~m}$, $1 \mathrm{lb}=0.453 \mathrm{~kg})$.

\begin{tabular}{|c|c|c|}
\hline \multirow[b]{2}{*}{ Source Size } & \multicolumn{2}{|c|}{ Fuel Loading } \\
\hline & $\begin{array}{l}\text { Low } \\
\mathrm{n} \times 1-\mathrm{A} \\
\text { PHRR, MW } \\
\text { Mass, lbs (kg) }\end{array}$ & $\begin{array}{l}\text { High } \\
\mathrm{n} \times 1-\mathrm{A} \\
\text { PHRR, MW } \\
\text { Mass, lbs (kg) }\end{array}$ \\
\hline Closet $(3 \mathrm{ft} \times 5 \mathrm{ft}), 15 \mathrm{ft}^{2}$ & $\begin{array}{l}2 \times 1-\mathrm{A} \\
0.58 \\
115(52)\end{array}$ & $\begin{array}{l}4 \times 1-\mathrm{A} \\
1.16 \\
229(104)\end{array}$ \\
\hline Very Small $(3 \mathrm{ft} \times 6 \mathrm{ft}), 18 \mathrm{ft}^{2}$ & $\begin{array}{l}3 \times 1-\mathrm{A} \\
0.87 \\
172(78)\end{array}$ & $\begin{array}{l}6 \times 1-\mathrm{A} \\
1.74 \\
344(156)\end{array}$ \\
\hline Small $(4 \mathrm{ft} \times 8 \mathrm{ft}), 32 \mathrm{ft}^{2}$ & $\begin{array}{l}6 \times 1-\mathrm{A} \\
1.74 \\
344(156)\end{array}$ & $\begin{array}{l}12 \times 1-\mathrm{A} \\
3.49 \\
688(312)\end{array}$ \\
\hline Medium $(8 \mathrm{ft} \times 8 \mathrm{ft}), 64 \mathrm{ft}^{2}$ & $\begin{array}{l}3 \times 6-A \\
5.12 \\
1016(461)\end{array}$ & $\begin{array}{l}6 \times 6-A \\
10.24 \\
2033(922)\end{array}$ \\
\hline Large $(10 \mathrm{ft} \times 12 \mathrm{ft}), 120 \mathrm{ft}^{2}$ & $\begin{array}{l}6 \times 6-A \\
10.24 \\
2033(922)\end{array}$ & $\begin{array}{l}12 \times 6-A \\
20.49 \\
4083(1843)\end{array}$ \\
\hline Very Large $(12 \mathrm{ft} \times 24 \mathrm{ft}), 288 \mathrm{ft}^{2}$ & $\begin{array}{l}15 \times 6-A \\
25.61 \\
5080(2304)\end{array}$ & $\begin{array}{l}30 \times 6-A \\
51.22 \\
10160(4608)\end{array}$ \\
\hline
\end{tabular}

Additional fuel loading calculations are presented in Table A-2 (fuel load per unit area) and Table A-3 (total mass of shed plus wood crib fuel load).

Table A-2: Source fuel loading.

\begin{tabular}{|l|l|l|}
\hline \multirow{2}{*}{ Source Size } & \multicolumn{2}{|c|}{ Fuel Loading, $\mathbf{M J} / \mathbf{m}^{2}$} \\
\cline { 2 - 3 } & Low & High \\
\hline Closet $(3 \mathrm{ft} \times 5 \mathrm{ft}) 15 \mathrm{ft}^{2}$ & 716 & 1432 \\
\hline Very Small $(3 \mathrm{ft} \times 6 \mathrm{ft}) 18 \mathrm{ft}^{2}$ & 895 & 1791 \\
\hline Small $(4 \mathrm{ft} \times 8 \mathrm{ft}) 32 \mathrm{ft}^{2}$ & 1007 & 2014 \\
\hline Medium $(8 \mathrm{ft} \times 8 \mathrm{ft}) 64 \mathrm{ft}^{2}$ & 1488 & 2976 \\
\hline Large $(10 \mathrm{ft} \times 12 \mathrm{ft}) 120 \mathrm{ft}^{2}$ & 1587 & 3175 \\
\hline Very Large $(12 \mathrm{ft} \times 24 \mathrm{ft}) 288 \mathrm{ft}^{2}$ & 1653 & 3307 \\
\hline
\end{tabular}


Table A-3: Maximum mass of source structures (mass of shed + mass of cribs) $(1 \mathrm{ft}=0.0305 \mathrm{~m}, 1 \mathrm{lb}=0.453 \mathrm{~kg})$.

\begin{tabular}{|c|c|c|c|}
\hline \multirow[b]{2}{*}{ Source Size } & \multicolumn{3}{|c|}{ Total Mass (shed with high fuel loading), lb (kg) } \\
\hline & Wood & Steel & Plastic/Composite \\
\hline $\begin{array}{l}\text { Closet } \\
(3 \mathrm{ft} \times 5 \mathrm{ft})\end{array}$ & $95+229=324(147)$ & $93+229=322(146)$ & $56+229=285(129)$ \\
\hline $\begin{array}{l}\text { Very Small } \\
(3 \mathrm{ft} \times 6 \mathrm{ft})\end{array}$ & $160+344=504(229)$ & $82+344=426(193)$ & $155+344=499(226)$ \\
\hline $\begin{array}{l}\text { Small } \\
(4 \mathrm{ft} \times 8 \mathrm{ft})\end{array}$ & $398+688=1086(493)$ & $115+688=803(364)$ & $126+688=814(369)$ \\
\hline $\begin{array}{l}\text { Medium } \\
(8 \mathrm{ft} \times 8 \mathrm{ft})\end{array}$ & $\begin{array}{r}1178+2033=3211 \\
(1456)\end{array}$ & $\begin{array}{r}140+2033=2173 \\
(986) \\
\end{array}$ & $\begin{array}{r}240+2033=2273 \\
(1031)\end{array}$ \\
\hline $\begin{array}{l}\text { Large } \\
(10 \mathrm{ft} \times 12 \mathrm{ft})\end{array}$ & $\begin{array}{r}3000+4083=7083 \\
(3209)\end{array}$ & $281+4083=4364(1977)$ & $\begin{array}{r}869+4083=4952 \\
(2246)\end{array}$ \\
\hline $\begin{array}{l}\text { Very Large } \\
(12 \mathrm{ft} \times 24 \mathrm{ft})\end{array}$ & $2100+10160=\underset{(5554)}{12260}$ & $\begin{array}{r}715+10160=10875 \\
(4926)\end{array}$ & $\begin{aligned} 512+10160= & 10672 \\
& (4840)\end{aligned}$ \\
\hline
\end{tabular}




\section{Crib Layouts in Sheds}

The following schematics show shed dimensions and potential crib layout for maximum floor coverage. Cribs will be stacked for the highest fuel loading configurations as shown below.
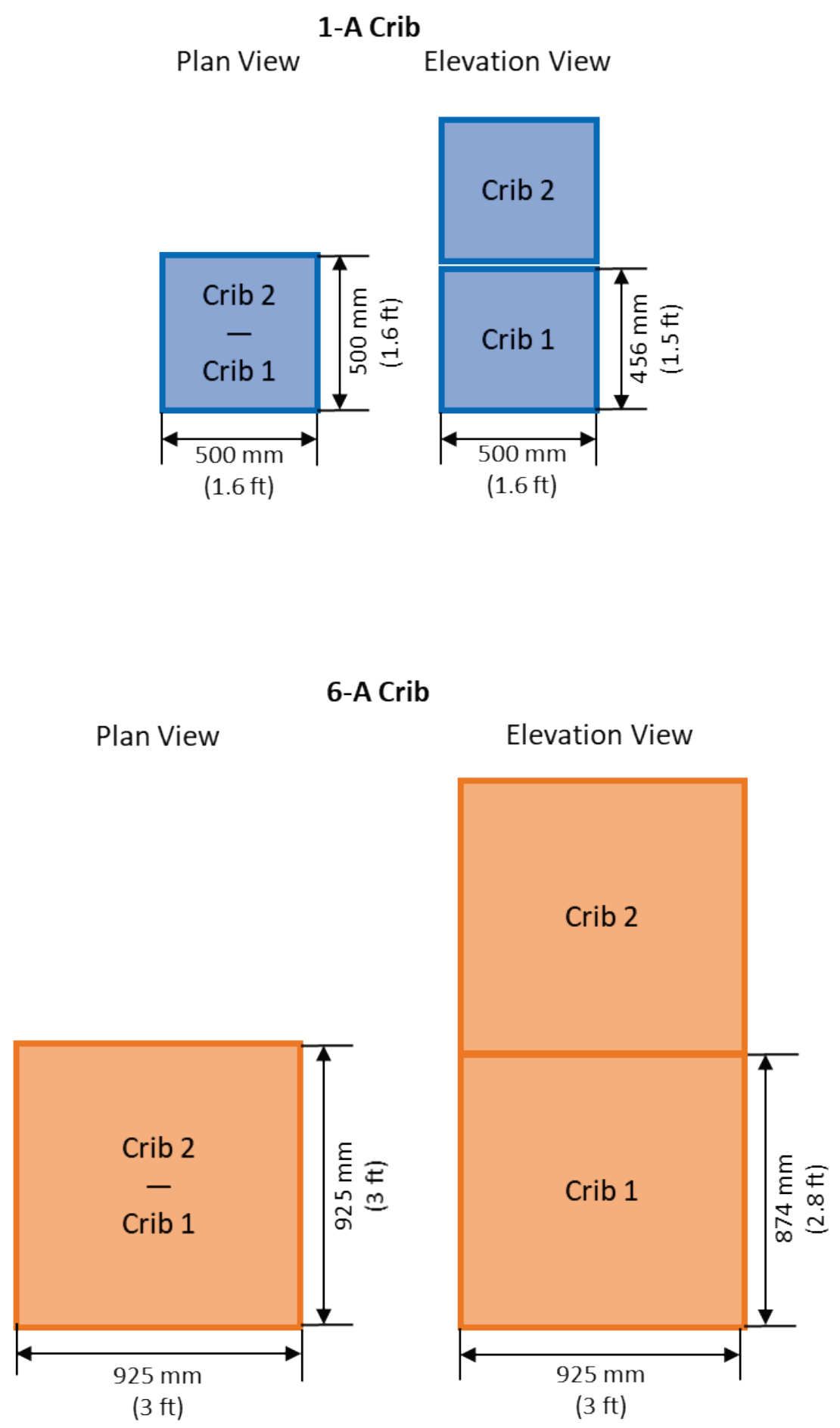
Closet: $3 \mathrm{ft} \times 5 \mathrm{ft} \times 4 \mathrm{ft}$

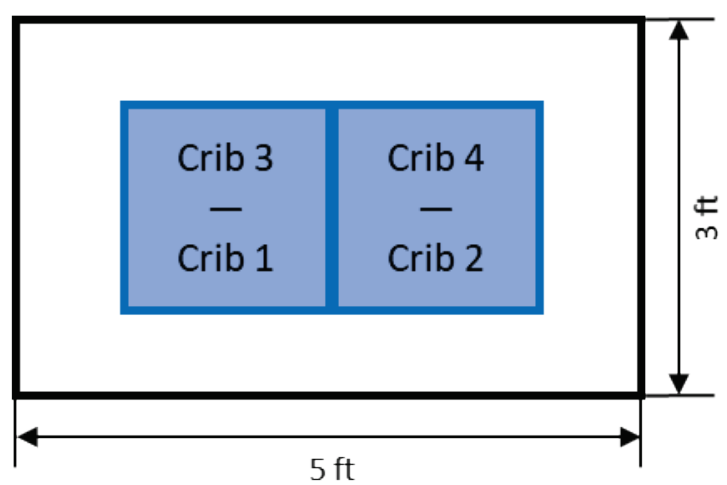

Very Small Shed: $3 \mathrm{ft} \times 6 \mathrm{ft} \times 6 \mathrm{ft}$

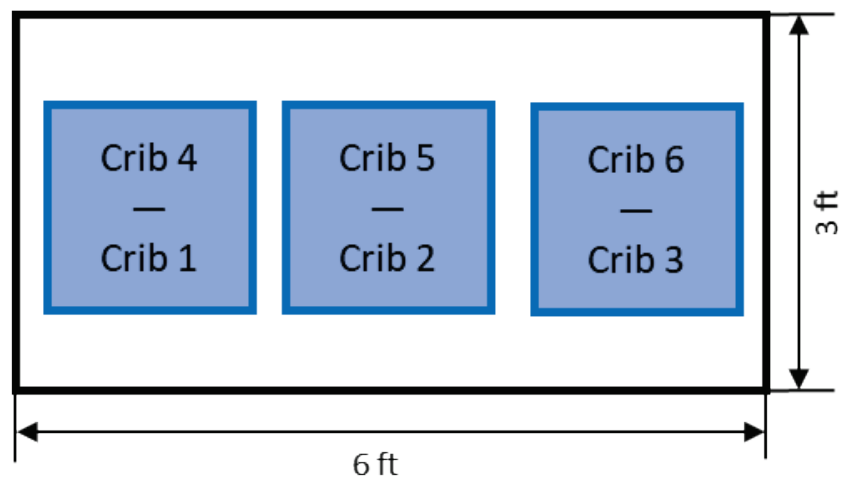

Small Shed: $4 \mathrm{ft} \times 8 \mathrm{ft} \times 8 \mathrm{ft}$

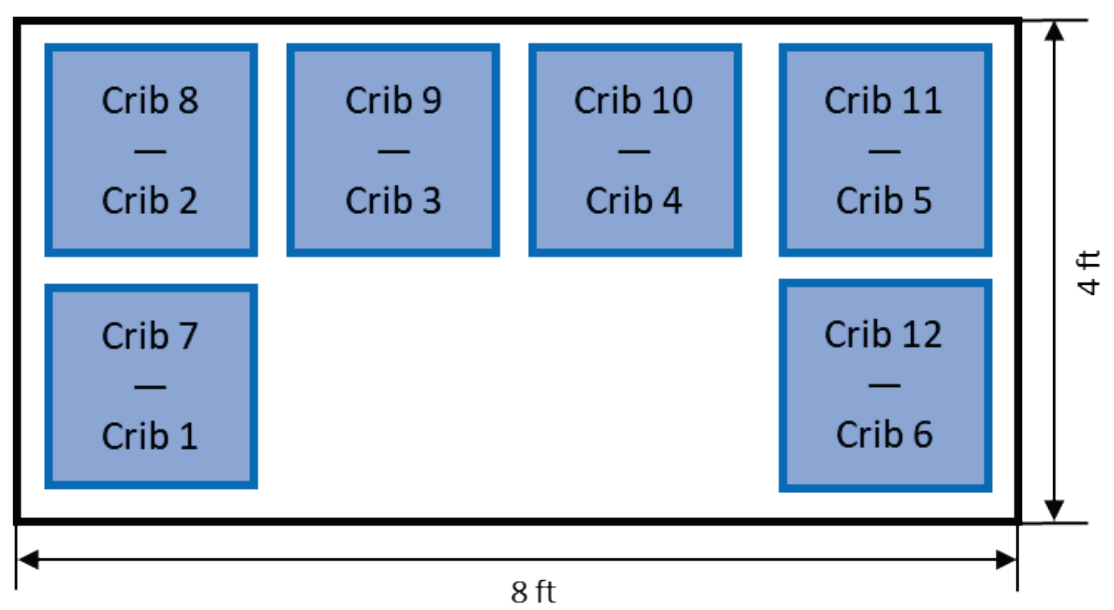


Medium Shed: $8 \mathrm{ft} \times 8 \mathrm{ft} \times 8 \mathrm{ft}$
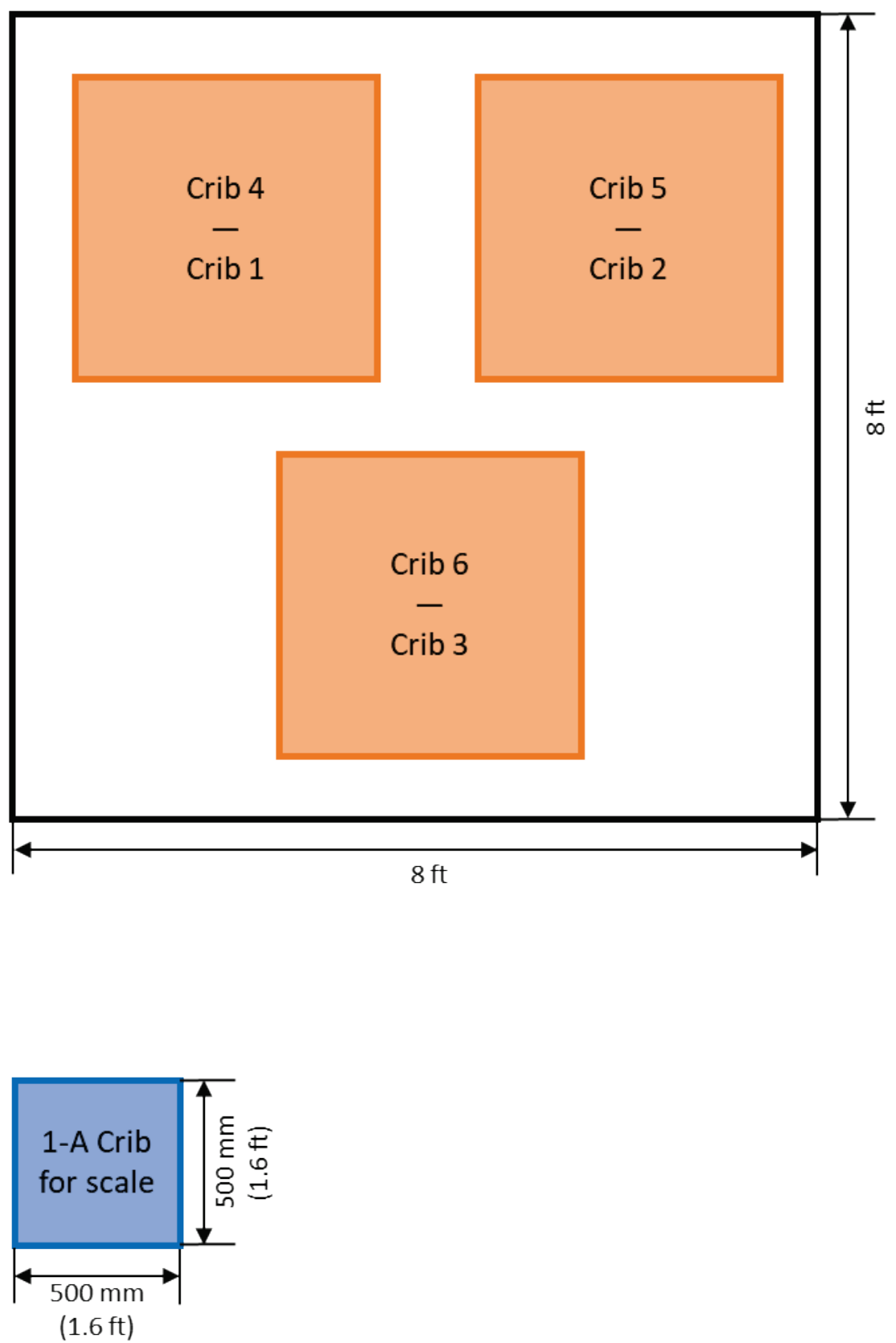
Large Shed: $10 \mathrm{ft} \times 12 \mathrm{ft} \times 8 \mathrm{ft}$

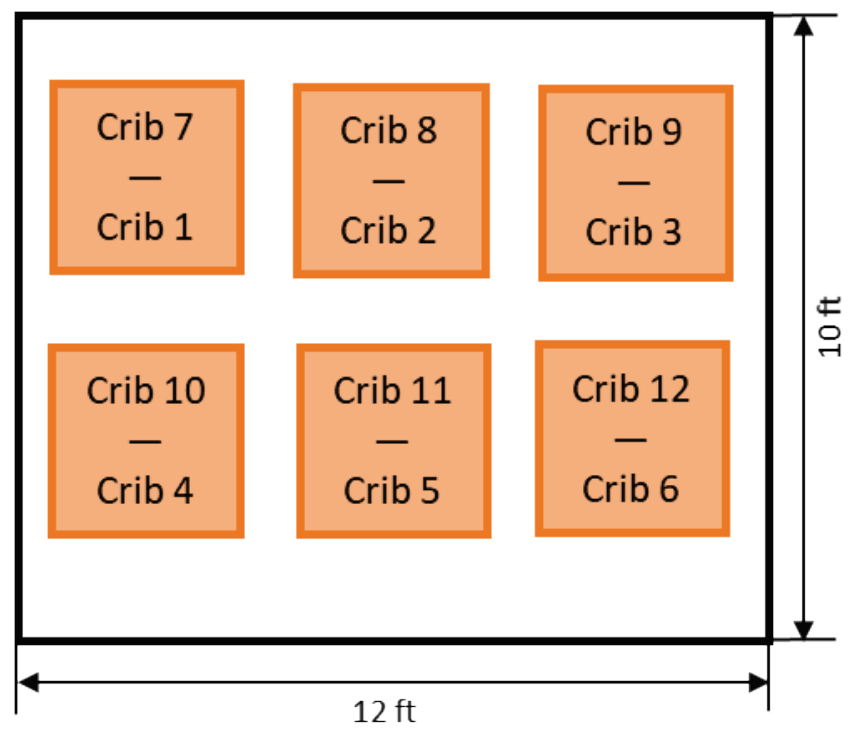

Very Large Shed: $12 \mathrm{ft} \times 24 \mathrm{ft} \times 10 \mathrm{ft}$

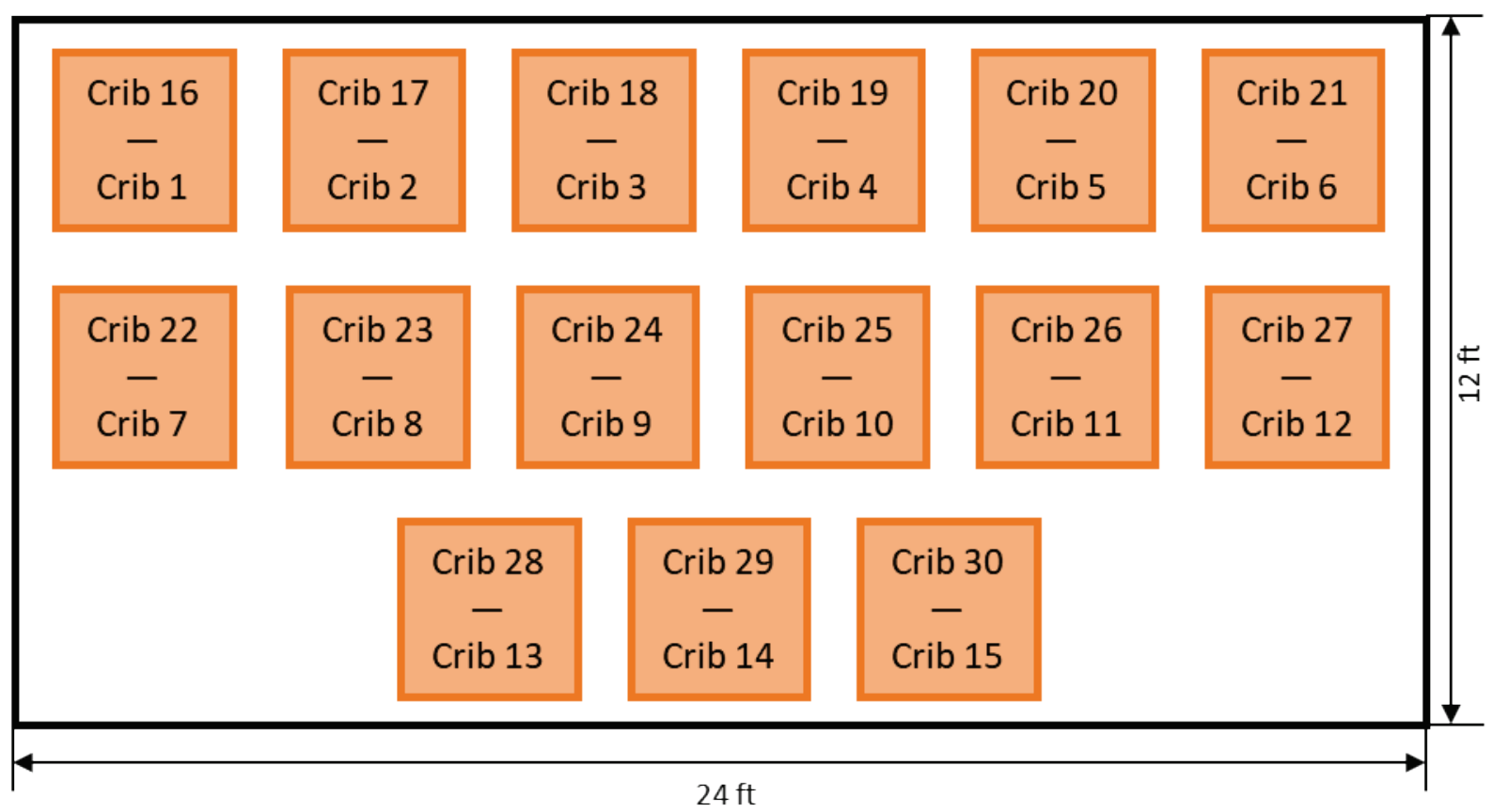




\section{Appendix B. Weighing Platform Design}

\section{B.1 NIST Platform}

The design features of the weighing platform used in NIST shed burn experiments are listed below:

- The horizontal footprint of the weighing platform will be approximately $5.8 \mathrm{~m} \times$ $5.8 \mathrm{~m}(19 \mathrm{ft} \times 19 \mathrm{ft})$. A drawing of the proposed platform truss system is presented in Figure B-1.

- The platform will be less than $0.6 \mathrm{~m}$ (24 in.) from the lab floor to the top of the platform due to height restrictions to the exhaust hood; refer to Figure 5.

- The platform framing and decking will be as light as feasible to improve the accuracy of source mass loss measurements.

- The source term loads (shed + cribs) for the Phase 1B NIST shed burn experiments will be up to "Medium" as defined in Table A-3. Table B-1 and Table B-2 list the loading design criteria for the Phase 1B NIST weighing platform.

- Source (shed) will be centered on the platform or centered along one edge; conservatively assuming that each weighing module will carry $50 \%$ of the total load. One weighing module will be used at each corner of the platform (four total); indeterminant load distribution will require initial leveling at each module to achieve equal load distribution. A diagram of the weighing module is shown in Figure B-2.

- The platform framing and weighing modules will be protected from heating above $50{ }^{\circ} \mathrm{C}$.

- Weighing module fixtures will be designed to accommodate the anticipated rotation and translation at the bearing points.

- Wood cribbing will be used to support the frame during setup and pre-test; as required for stability. 
Table B-1: Design loads for weighing modules for Phase 1B NIST shed burn experiments; final values provided in SI units.

$\begin{array}{cl}\text { Platform Length } & 19 \mathrm{ft} \\ \text { Width } & 19 \mathrm{ft}\end{array}$

\begin{tabular}{|c|c|c|c|c|c|}
\hline Category & Item & Amount & Weight & Total, Ibm & Remarks \\
\hline Source & shed + cribs (max) & 1 unit & $3200-$ & 3200 & Maximum; distributed over $8^{\prime} \times 8^{\prime}$ \\
\hline \multirow[t]{4}{*}{ Deck } & 1.5" B-Deck & $361 \mathrm{sq}-\mathrm{ft}$ & $1.9 \mathrm{lbm} / \mathrm{sq}-\mathrm{ft}$ & 686 & \\
\hline & 5/8" gypboard layer 1 & $361 \mathrm{sq}-\mathrm{ft}$ & $2.2 \mathrm{lbm} / \mathrm{sq}-\mathrm{ft}$ & 794 & SHEETROCK $^{\circledR}$ BRAND FIRECODE $^{\circledR} \mathrm{X}$ \\
\hline & $1 / 2$ " cement board & $361 \mathrm{sq}-\mathrm{ft}$ & $2.4 \mathrm{lbm} / \mathrm{sq}-\mathrm{ft}$ & 866 & $1 / 2$ in. USG Durock ${ }^{\circledast}$ \\
\hline & & & & 2347 & \\
\hline \multirow[t]{4}{*}{ Framing } & Modular truss & $114 \mathrm{lft}$ & $5.5 \mathrm{lbm} / \mathrm{ft}$ & 628 & Milos M290V \\
\hline & & & & 6175 & Source + Deck + Frame \\
\hline & & & Max per module & 3087 & Ibm (Total weight / 2) \\
\hline & & & Max per module & 1400 & $\mathrm{~kg}$ \\
\hline
\end{tabular}

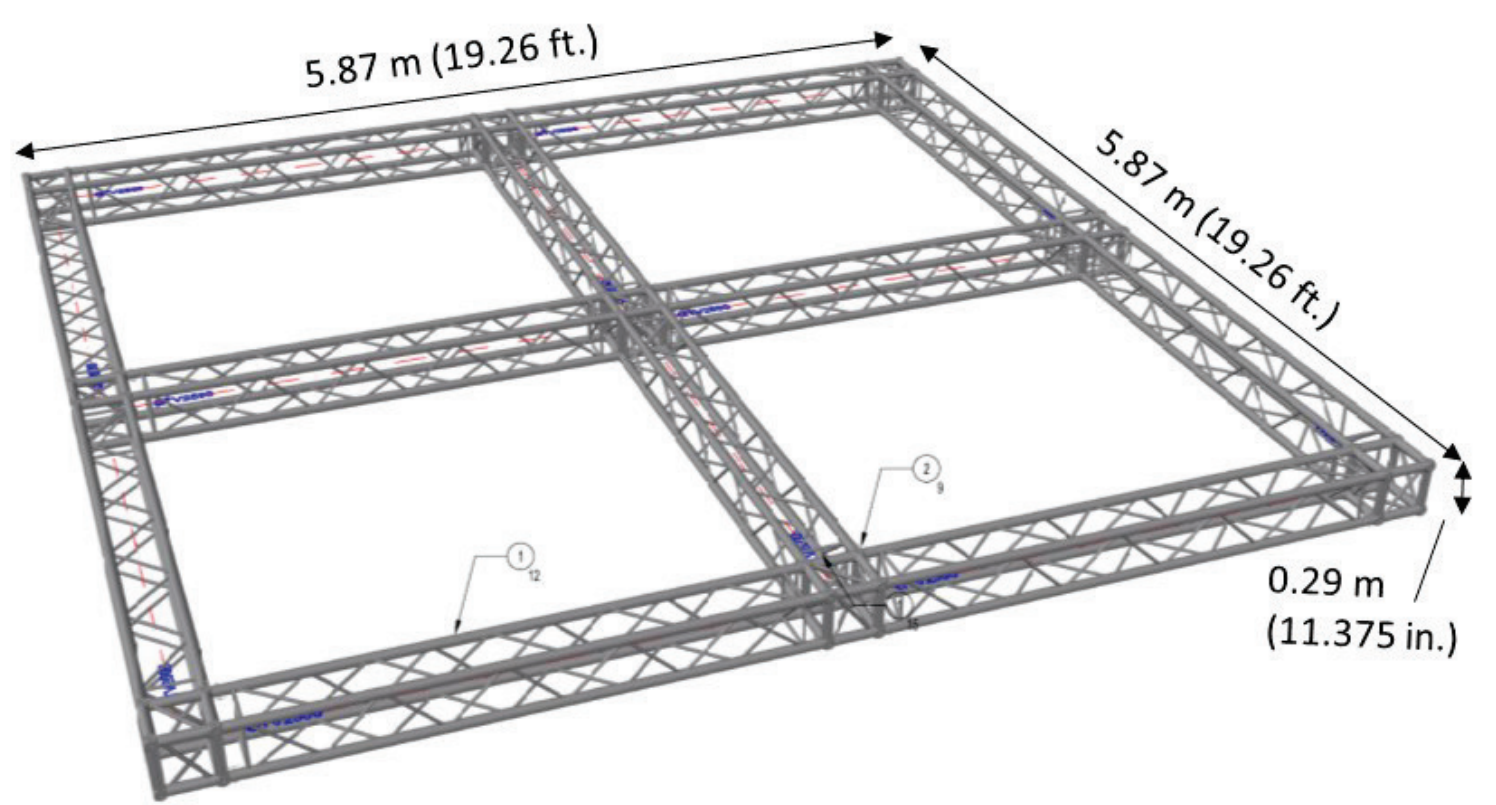

Figure B-1: Scale drawing of proposed modular truss framing for weighing platform during Phase 1B NIST shed burn experiments (source: www.milossystems.com). 


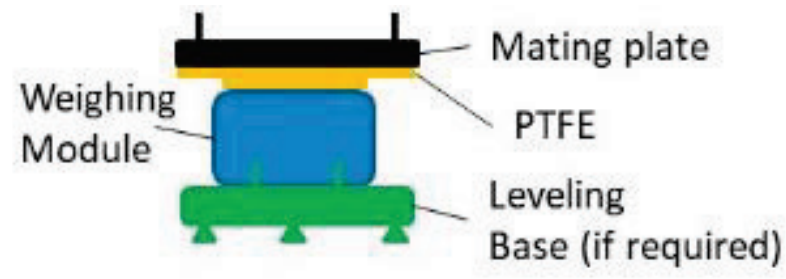

(a)

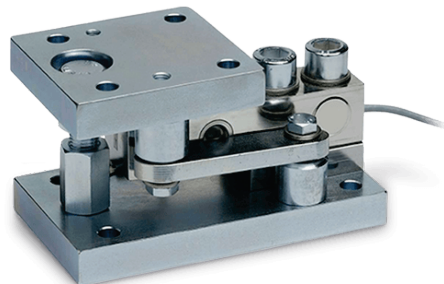

(b)

Figure B-2: Proposed weighing module with fixture for weighing platform for Phase 1B experiments at NIST: (a) schematic for weighing module with the fixture (not to scale; PTFE = Polytetrafluoroethylene); (b) proposed weighing module (source: www.hbm.com).

\section{B.2 IBHS Platform}

Approximate dimensions of weighing platform for L and VL sheds are given in Table B-2. The minimum dimension would be $24 \mathrm{ft} \times 24 \mathrm{ft}(7.31 \mathrm{~m} \times 7.31 \mathrm{~m})$ while maximum dimension would be $36 \mathrm{ft} \times 36 \mathrm{ft}$. The later considers maximum SSD for the VL sheds $12 \mathrm{ft} \times 24 \mathrm{ft}$. The design of the weighing platform must account for slope and load bearing capacity of the test area.

Table B-2: SSD range and platform size range for IBHS shed burn experiments $(1 \mathrm{ft}=0.305 \mathrm{~m})$.

\begin{tabular}{|l|l|l|l|}
\hline Source Size & Dimensions & SSD ft & Platform size \\
\hline $\mathrm{L}$ & $10 \mathrm{ft} \times 12 \mathrm{ft}$ & \multirow{2}{*}{$10 \mathrm{ft}$ to $30 \mathrm{ft}$ or $50 \mathrm{ft}$} & $\begin{array}{l}\text { IBHS } \\
36 \mathrm{ft} \times(66 \mathrm{ft} \text { to } 86 \mathrm{ft})\end{array}$ \\
\cline { 1 - 1 } VL & $12 \mathrm{ft} \times 24 \mathrm{ft}$ & & \\
\hline \multicolumn{4}{|l}{} \\
\hline Target size & $24 \mathrm{ft} \times 45 \mathrm{ft}$ (estimated) \\
\hline
\end{tabular}




\section{Appendix C. Target Structure Design Specifications}

\section{Wall assembly}

A front view of the target wall with nominal dimensions is shown in Figure C-1 below.

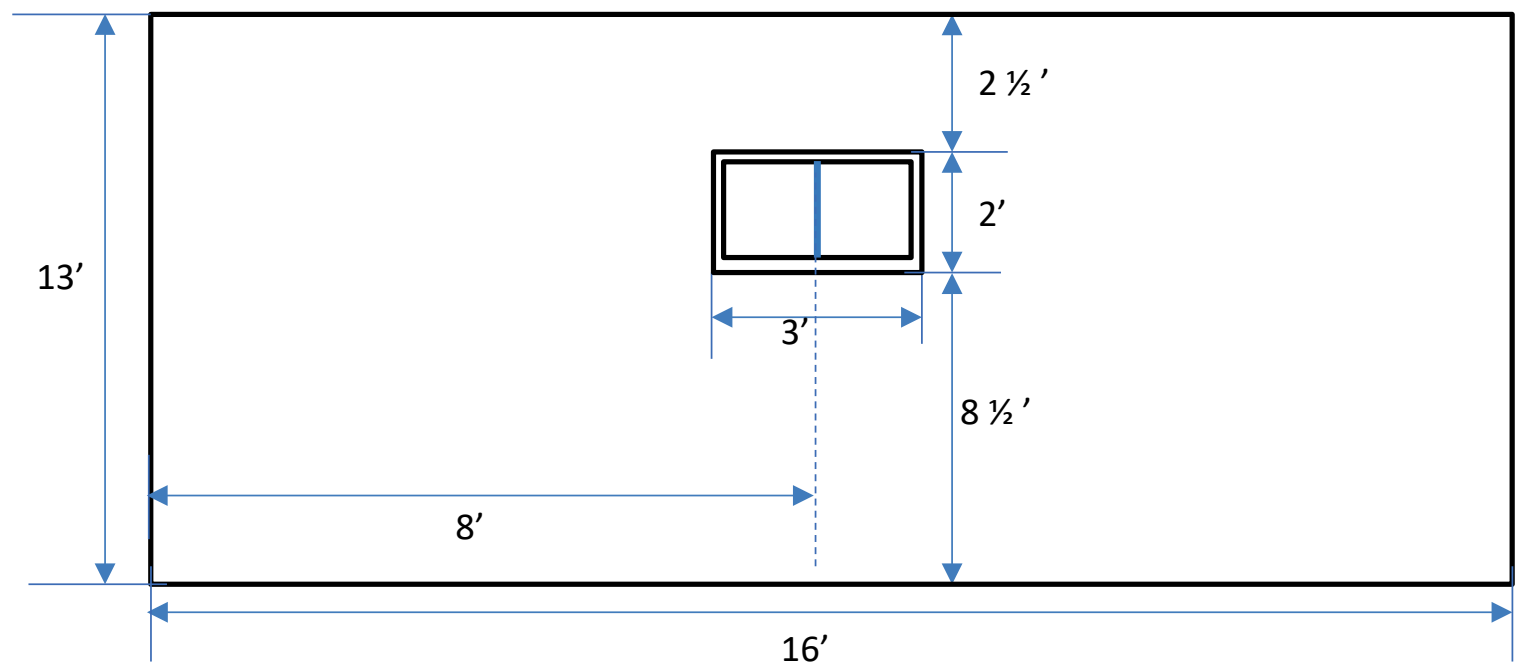

Figure C-1. Front view of the target wall with window.

A schematic of the wall assembly with layers of construction is shown in Figure C-2. The wall construction will comprise of following layers (from interior to exterior):

- $5 / 8$ " drywall (1 layer in the interior)

- 2 " $\times 4$ " studs

- 1 " mineral fiber insulation

- 7/16" OSB sheathing

- $5 / 8 "$ drywall (2 layers)

- 5/16" Fiber Cement Panel Siding

The materials for the target wall construction were selected from the materials listed on California Building Materials listing website. Welcome to BML Search Building Materials Listing (ca.gov) 


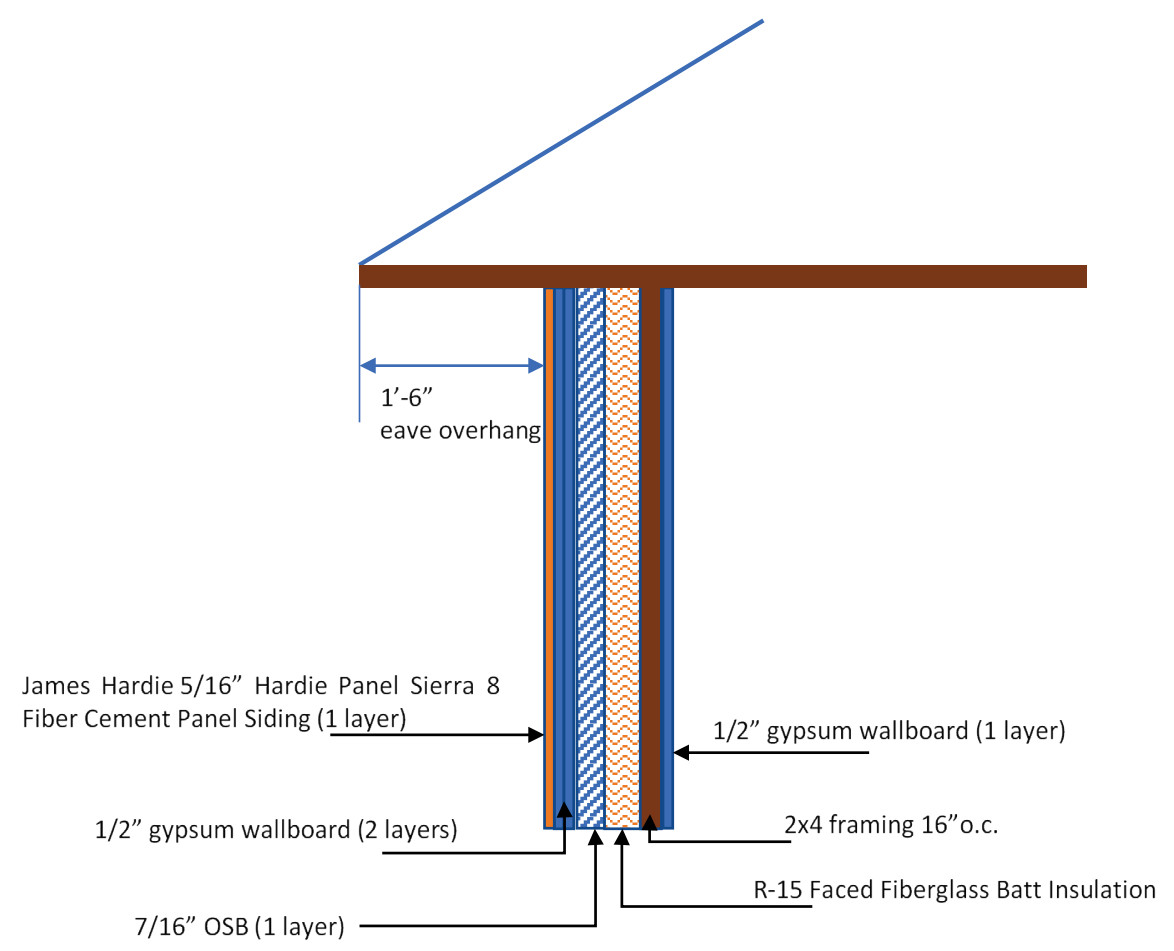

Figure C-2: Target wall construction details with roof overhang.

\section{Roof}

The roof will be built in compliance with California Chapter 7A requirements. Class A asphalt shingles will be used on 24" o.c. rafters

https://www.gaf.com/en-us/products/royal-sovereign

Color/Finish: Silver Lining

Roof underlayment with Class A fire rating (UL 790) will be used.

https://www.homedepot.com/p/GAF-Tiger-Paw-1000-sq-ft-Premium-Synthetic-Roofing-

Underlayment-Roll-0980/206885977

Gutters

https://www.homedepot.com/p/Spectra-Metals-6-in-X-8-ft-K-Style-Black-Aluminum-Gutter$\underline{6 \mathrm{KBK} 8 / 206305103}$

Drip Edge Flashing

https://www.homedepot.com/p/Amerimax-Home-Products-F5M-2-33-in-X-1-5-in-x-10-ftAluminum-Black-Drip-Edge-Flashing-5564535120/203484742

\section{Eave}

An open eave construction with an eave overhang distance of 18 " will be used. The eave height of 13' from AGL (Above Ground Level) assumes $9 \mathrm{ft}$ ceilings and a crawlspace as shown in Figure C-3. 


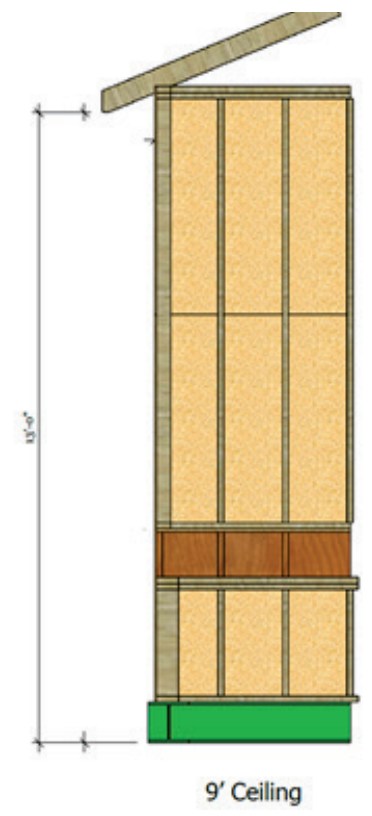

Figure C-3: Eave height above ground level

\section{Venting}

Fire resistant eave vents with intumescent coating will be used. These eave vents are generally recommended for residential construction in WUI areas. Vulcan eave vents with Reserve Tabs VE7522RT and nominal dimensions of 7.5" $\times 22$ " will be used.

https://www.vulcanvents.com/eave-vents/

\section{Window}

36 in. $\times 24$ in. 70 Series Universal/Reversible Sliding White Vinyl Window with Buck Frame American Craftsman 36 in. x 24 in. 70 Series Universal/Reversible Sliding White Vinyl Window with Buck Frame-70 SLIDER BUCK - The Home Depot 


\section{Appendix D. IBHS Experiments-SSD and Instrumentation}

Phase 1B IBHS shed burn experiments will explore structure separation distances for different orientations of structures relative to the wind direction. Target orientation for various shed sizes are given in Table D-1. These experiments will particularly examine exposures from large and very large sheds. Figure D-1 to Figure D-3 illustrate the relative orientations of the source and target structures with respect to the wind and structure separation distances. Test specifications and instrumentation for IBHS shed burn experiments with and without wind are given in Table D-2 and Table D- 3.

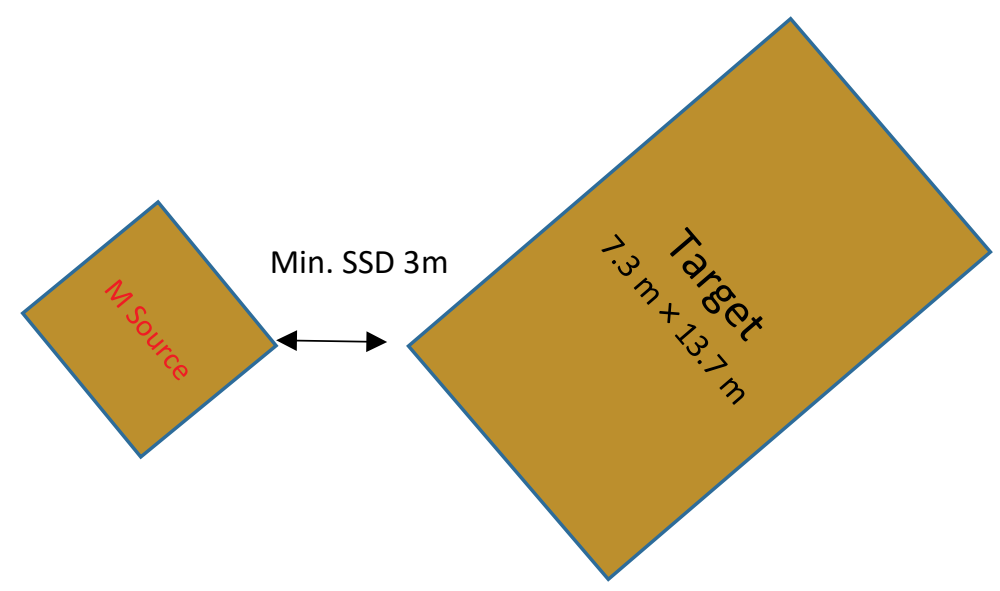

Figure D-1: IBHS shed orientation: Medium shed at $45^{\circ}$ and target at $45^{\circ}$ (figure not to scale).

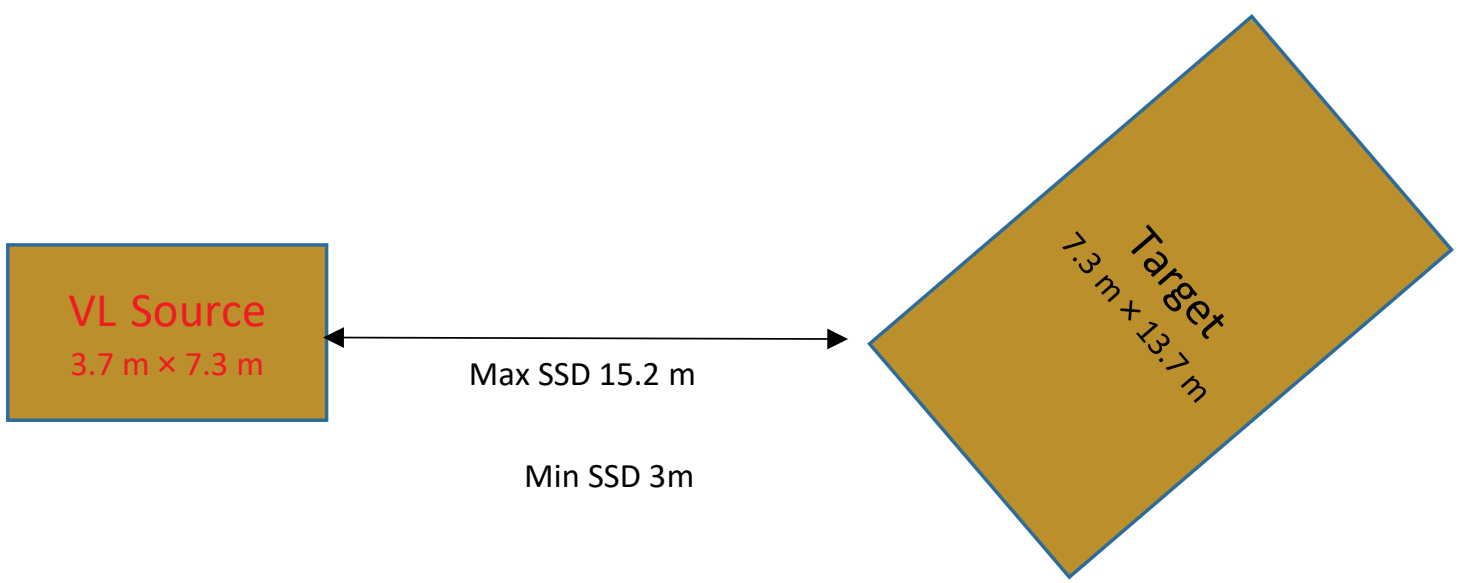

Figure D-2: IBHS shed orientation: Very large shed at $0^{\circ}$ and target at $45^{\circ}$ (figure not to scale). 


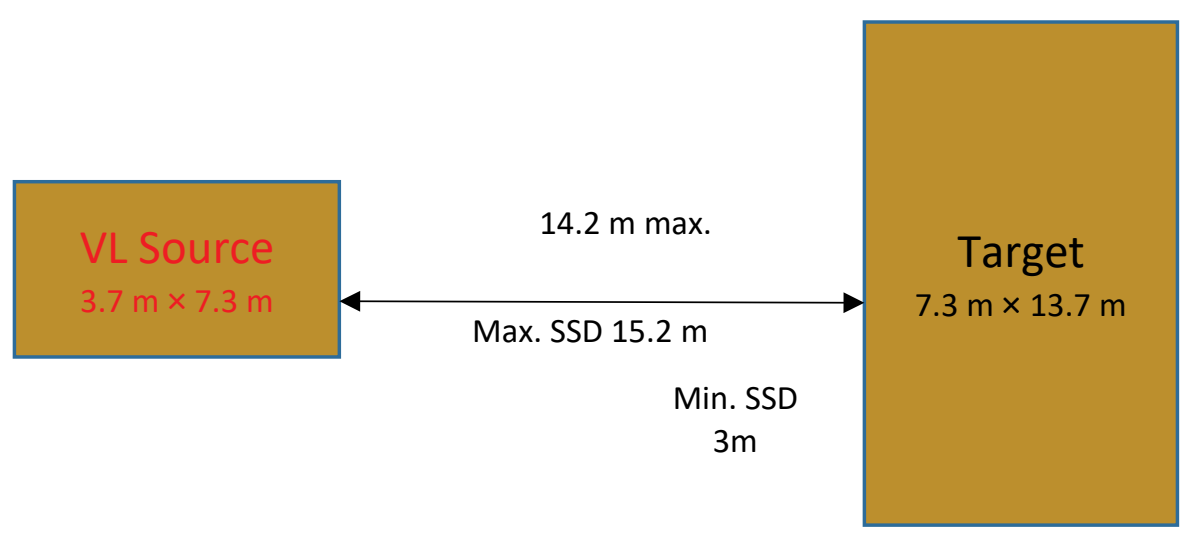

Figure D-3: IBHS shed orientation: Very large shed at $0^{\circ}$ and target at $90^{\circ}$ (figure not to scale).

Table D-1: Target orientation for various shed sizes for IBHS shed burn experiments.

\begin{tabular}{|l|l|}
\hline Source Size & $\begin{array}{l}\text { Degrees of long axis of shed } \\
\text { from wind direction }\end{array}$ \\
\hline $\mathrm{M}$ & $0^{\circ}$ or $45^{\circ}$ \\
\hline $\mathrm{L}$ & $0^{\circ}$ or $45^{\circ}$ \\
\hline $\mathrm{VL}$ & $0^{\circ}$ \\
\hline * Target orientation will not vary between experiments
\end{tabular}


Table D-2: Test specifications and instrumentation for IBHS shed burn experiments with and without wind $(1 \mathrm{ft}=0.0305 \mathrm{~m})$.

\begin{tabular}{|c|c|c|c|c|c|}
\hline Test ID & $\begin{array}{c}\text { Source } \\
\text { Construction }\end{array}$ & Shed size, ft & $\begin{array}{l}\text { Heat } \\
\text { Flux }\end{array}$ & $\begin{array}{l}\text { Plume } \\
\text { Temp. }\end{array}$ & Wind \\
\hline 1B-WMh0 & Wood & $\begin{array}{c}\mathrm{L} \\
(10 \mathrm{ft} \times 12 \mathrm{ft})\end{array}$ & $\mathrm{Y}$ & $\mathrm{Y}$ & $\mathrm{N}$ \\
\hline 1B-7ALh0 & \multirow[b]{2}{*}{ Chapter 7A } & $\begin{array}{c}\mathrm{L} \\
(10 \mathrm{ft} \times 12 \mathrm{ft})\end{array}$ & Y & Y & $\mathrm{N}$ \\
\hline 1B-7AVLh0 & & $\begin{array}{c}\mathrm{VL} \\
(10 \mathrm{ft} \times 14 \mathrm{ft}) \\
\text { or } \\
(16 \mathrm{ft} \times 16 \mathrm{ft})\end{array}$ & Y & Y & $\mathrm{N}$ \\
\hline 1B-SLh0 & \multirow[b]{2}{*}{ Steel } & $\begin{array}{c}\mathrm{L} \\
(10 \mathrm{ft} \times 12 \mathrm{ft})\end{array}$ & Y & Y & $\mathrm{N}$ \\
\hline 1B-SVLh0 & & $\begin{array}{c}\mathrm{VL} \\
(10 \mathrm{ft} \times 14 \mathrm{ft}) \\
\text { or } \\
(16 \mathrm{ft} \times 16 \mathrm{ft})\end{array}$ & Y & Y & $\mathrm{N}$ \\
\hline 1B-PLh0 & Plastic/Composite & $\begin{array}{c}\mathrm{L} \\
(10 \mathrm{ft} \times 12 \mathrm{ft})\end{array}$ & Y & Y & $\mathrm{N}$ \\
\hline 1B-WMhV & Wood & $\begin{array}{c}\mathrm{L} \\
(10 \mathrm{ft} \times 12 \mathrm{ft})\end{array}$ & Y & $\mathrm{N}$ & $\begin{array}{c}\text { Varying } \\
\text { wind }\end{array}$ \\
\hline 1B-7ALhV & Chapter 7A* & $\begin{array}{c}\mathrm{L} \\
(10 \mathrm{ft} \times 12 \mathrm{ft})\end{array}$ & Y & $\mathrm{N}$ & $\begin{array}{l}\text { Varying } \\
\text { wind }\end{array}$ \\
\hline 1B-R TBD & TBD & TBD & Y & $\mathrm{N}$ & $\begin{array}{c}\text { Varying } \\
\text { wind }\end{array}$ \\
\hline
\end{tabular}


Table D-3: Test specifications and instrumentation for IBHS shed burn experiments with wind and SSD $(1 \mathrm{ft}=0.0305 \mathrm{~m})$.

\begin{tabular}{|c|c|c|c|c|c|c|}
\hline Test ID & $\begin{array}{c}\text { Shed } \\
\text { Construction }\end{array}$ & Shed Size & $\begin{array}{c}\text { SSD } \\
\text { (ft) }\end{array}$ & $\begin{array}{c}\text { Heat } \\
\text { fluxes }\end{array}$ & $\begin{array}{l}\text { In-shed } \\
\text { imaging }\end{array}$ & $\begin{array}{l}\text { Wind } \\
(\mathrm{mi} / \mathrm{h})\end{array}$ \\
\hline 1B-TBD & Wood & $\begin{array}{c}\mathrm{L} \\
(10 \mathrm{ft} \times 12 \mathrm{ft})\end{array}$ & TBD & Y & Y & Baseline* \\
\hline 1B-TBD & Wood & $\begin{array}{c}\mathrm{L} \\
(10 \mathrm{ft} \times 12 \mathrm{ft})\end{array}$ & TBD & Y & $\mathrm{Y}$ & Baseline \\
\hline 1B-TBD & $\begin{array}{c}\text { Chapter 7A } \\
\text { complaint }\end{array}$ & $\begin{array}{c}\text { VL } \\
(10 \mathrm{ft} \times 14 \mathrm{ft}) \\
\text { or } \\
(16 \mathrm{ft} \times 16 \mathrm{ft})\end{array}$ & TBD & Y & Y & Baseline \\
\hline 1B-TBD & $\begin{array}{l}\text { Chapter 7A } \\
\text { compliant }\end{array}$ & $\begin{array}{c}\mathrm{VL} \\
(10 \mathrm{ft} \times 14 \mathrm{ft}) \text { or } \\
(16 \mathrm{ft} \times 16 \mathrm{ft})\end{array}$ & TBD & Y & Y & Baseline \\
\hline 1B-TBD & Wood & $\begin{array}{c}\mathrm{L} \\
(10 \mathrm{ft} \times 12 \mathrm{ft})\end{array}$ & TBD & Y & Y & Baseline \\
\hline 1B-TBD & $\begin{array}{l}\text { Chapter 7A } \\
\text { complaint }\end{array}$ & $\begin{array}{c}\mathrm{VL} \\
(10 \mathrm{ft} \times 14 \mathrm{ft}) \text { or } \\
(16 \mathrm{ft} \times 16 \mathrm{ft})\end{array}$ & TBD & Y & Y & Baseline \\
\hline 1B-Wind1 & TBD & \multirow{2}{*}{\multicolumn{2}{|c|}{$\begin{array}{l}\text { Wind experiments, } \\
\text { conditions TBD }\end{array}$}} & Y & Y & $\begin{array}{l}\text { Second } \\
\text { wind } \\
\text { speed }\end{array}$ \\
\hline 1B-Wind 2 & TBD & & & $\mathrm{Y}$ & Y & TBD \\
\hline 1B-R1 & \multirow{2}{*}{\multicolumn{6}{|c|}{ Replicate experiments - Conditions TBD }} \\
\hline 1B-R2 & & & & & & \\
\hline 1B-T1 & \multicolumn{6}{|c|}{ TBD. Conditions to be determined. Target instrumented for heat fluxes. } \\
\hline 1B-T1R & \multicolumn{6}{|c|}{ Replicate of 1B-T1 } \\
\hline
\end{tabular}

* Baseline wind may be different for different shed sizes. 


\section{Appendix E. IBHS Experiments: Vulnerabilities of Structure Corners}

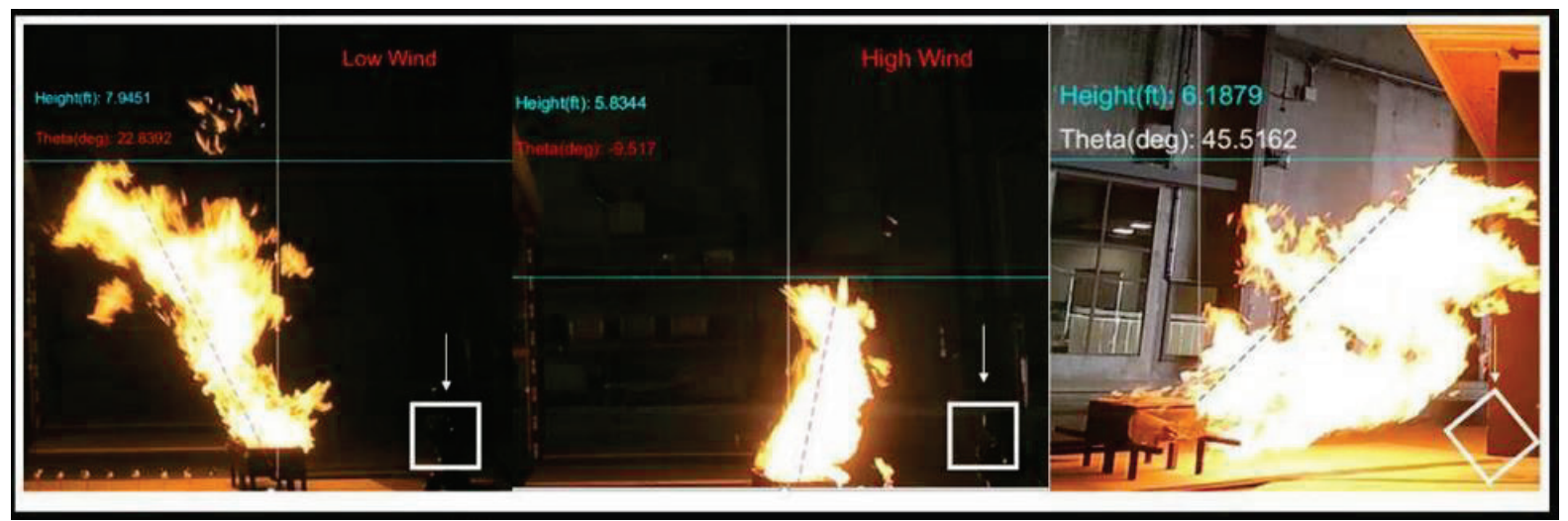

Image Source: IBHS

Left-hand side photo: Low wind with burner is placed at the middle of a $12.19 \mathrm{~m}$ (40 ft) wall

A tall flame tilts towards the house causing intense radiation and also direct flame contact to the wall.

Middle photo: High wind with burner placed at the middle of a $12.19 \mathrm{~m}$ (40 ft) wall

A short flame that is pushed away from the house due to intense vortices at high wind. In this case the radiation intensity on the wall was low and no flame contact happened.

Right-hand side photo: High wind with burner placed at the corner of the house A tall flame tilts towards the house at $45^{\circ}$ angle, causing extreme exposure. The intensity of this exposure on the wall was high enough to ignite the wall, resulting in termination of the test. 


\section{Appendix F. Preliminary Data Management and Quality Assurance Project Plan}

\section{F.1 Overview}

This appendix provides quality assurance for data handling procedures and processes to ensure that scientific data integrated, collected, and derived for the structure separation experiment are managed in a manner that meets the data quality objectives set forth for the project. The project will use Google Drive for data storage and dissemination during the experiments.

\section{F.2 Structure Separation Experiment data catalog information documentation}

A project data catalog is being developed to provide more details on the specific measurements and derived or compiled datasets. The project data catalog will also ensure that essential data elements are documented throughout the project, thereby providing a foundation for completing the final project metadata associated with each dataset. The data catalog will contain overview details on data quantity and quality, data quality objectives, contact information, and other information listed below to track and search project data:

- Dataset Name: The full name of the dataset.

- Data Type: The type of data (e.g., wind speed measurements from an anemometer would be "Point Data", a CAD file could be a "three-dimensional [3D] Data", and model outputs might be "Raster Data" or gridded data).

- Format: The file format (e.g., point data might be an "Excel File", and 3D Data might be "CAD Files").

- Start Date/Time: The start date and time of the individual measurements or the time for which the complied or derived data is applicable.

- End Date/Time: The end date and time of the individual measurements or the time for which the compiled or derived data is applicable.

- Summary: A short description of the data.

- Purpose: A short description of the purpose of the data.

- Source Description: A description of the data source (e.g., CAD file representing the $3 \mathrm{D}$ representations of the IBHS campus might have come from as-built drawings of the buildings).

- Source References: Any references to the source data descriptions above (e.g., published as-built drawing from which the development of CAD files occurred).

- Other Reference Descriptions: Descriptions to any other pertinent references to the source data (e.g., some data might contain a reference to the IBHS test facility or the NIST large fire lab).

- Other References: Any references that correspond to the descriptions provided above (e.g., the reference to the IBHS test facility might be as follows: https://ibhs.org/about-ibhs/ibhs-research-center/).

- Data Collection Method Descriptions: Descriptions of the data collection, compilation, or derivation methods used to collect, derive, or compile the particular dataset. 
- Data Collection Method References: Any references to the particular data collection, compilation, or derivation methods, if they exist.

- Data Quality Objectives: A description of the data quality objectives (DQO) for each measurement in the experiment. For example, cup anemometers might have a DQO that requires accuracy ranging between 1 to $5 \%$ for wind speed and wind direction measurements with a precision of one standard deviation of the mean.

- Quality Control Assessments: A description of the methodologies employed (i.e, quality control checks) to test if the data meets project DQOs. For example, anemometer wind direction measurements outside of one standard deviation from the mean do not meet project DQOs for data precision.

- Calibration Reports/Curves: The calibration reports or curves for the respective measurement. For example, calibrating anemometers every year might occur, including the creation of reports provided here. Also, the calibration of thermocouples typically occurs to produce interpretable measurements.

- Supporting or Ancillary Datasets: The supporting or ancillary datasets relevant to the data catalog's primary dataset. For example, 3D buildings derived from as-built drawings, which are not published, would be linked-to in this section.

- Experimental Series Name: The name or names of the experimental series for which the respective dataset applies.

- Measurement Quantity Per Experiment: The number or quantity of measurements contained within the respective dataset. For example, the IBHS cold flow wind measurements have 35 anemometers installed.

- Network Location: The location of the dataset on the project Google Drive.

- Key Words: Any key words associated with the dataset.

- Use Constraints: Any use or security constraints associated with the dataset.

- Link to Formal Metadata: The link to the formal metadata document.

- Contact Information: The full name or names of the individuals responsible for the respective dataset.

A Microsoft (MS) Excel spreadsheet will be created to store and document the above information on project data. Additionally, a separate spreadsheet containing descriptive information about each attribute within the respective dataset will be created. The information documented in this spreadsheet will include:

- Attribute Name: The full name of the attribute contained within each dataset.

- Attribute Definition: A complete definition of the attribute.

- Source Definition: The source of the definition of the attribute. In most cases, this will be the organization's name that collected or created the respective dataset.

- Units: The units associated with the respective measurement (e.g., wind speed in meters per second).

- Domain Values: The established list of values associated with the respective attribute, if applicable. For example, the shed type (C, S, VS, M, etc.).

- Data Type: The data type of the attribute (e.g., text, floating, etc.).

- Accuracy (+/-): The accuracy of the data within the respective attribute, if applicable.

- Precision: The precision of the dataset. 
- Measurement Frequency: The measurement frequency of the respective attribute (e.g., one hertz).

- Null Values: The code used to represent null values.

- Missing Value Code: The code used to represent missing values.

The creation of the above information during the project will facilitate creating formal metadata documents to meet the FAIR Guiding Principles for scientific data. The exact metadata format will be finalized as the project progresses.

\section{F.3 Structure Separation Experiment file and attribute naming conventions}

All project files will adhere to the following naming conventions:

- Files representing date-specific information will have names that include the date of the file in YYYYMMDD format. The date can occur anywhere within the name that is most logical for sorting.

- Additional elements of the file name can occur, providing additional descriptive information about the respective document as required. The maximum file path lengths should be less than 260 characters.

- An underscore (_) will be used as an element delimiter; no capital letters, no spaces or

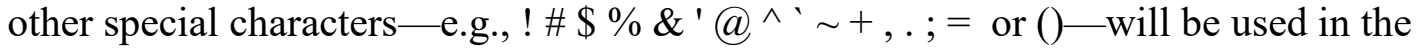
file name.

- A hyphen (-)will be used to delimit directory names when a specific order is desired to be maintained.

- Elements should be ordered based on the level of importance, as practical.

- Personal names within an element should have the family name first, followed by an underscore and the first names or initials.

- Numbers as part of elements will have leading zeros appropriate to ensure files sort in sequential order.

- Finally, the file names should be as concise as possible while providing sufficient descriptive information for those unfamiliar with the project to understand the file contents.

All data files will adhere to the following naming conventions:

- All attribute names should be as exact and English-lie as possible, within the naming convention's confines below. Ideally, attribute names are evident to the casual user in the context of the respective dataset. It is not practical to achieve this for all names. Nonetheless, measurement specialists should consider this principle when naming attributes.

- Attribute names should be as short as possible while still retaining meaning and uniqueness within the database. Measurement specialists should favor clarity when any conflicts between this and the principle of clarity arise. Again, this is within the confines of the naming conventions below.

- All attribute names will be lower case.

- All attribute names will begin with an alphabetic value (e.g., a through z). 
- Attribute names will contain only alphanumeric values (e.g., a through z or 1 through 9).

- Attribute names representing date-specific information will have names that include the file's date in YYYYMMDD format or some subset if only a month or day is required.

- All attribute names represent one single data element (e.g., wind speed in meters per second).

- All attribute names will use the singular form only (e.g., an attribute describing walls will be named as "wall" not "walls").

- An underscore ( $\_$) will be used as an element delimiter; no capital letters, no spaces,

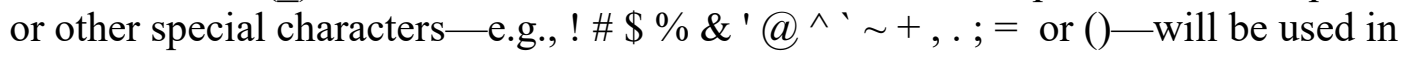
the file name (e.g., wall height could be represented as "wall_height", "wall_hgt" or some other initutive name following the rules above and below.

- Attribute names for data elements representing measurements with a unit of measure (e.g., wind speed in meters per second) will have the attribute element's final part of the name as a code representing the measuring unit (e.g., speed_mps for a table of wind speed measurements), prefixed by an underscore. See the spreadsheet attribute_names_unit_abbreviations.xlsx for a list of codes.

- Attribute names should be less than 63 characters.

\section{F.4 Structure Separation Experiment tabular, raster, image, and video data structure conventions}

All tabular data will adhere to the following data structure and data format conventions:

- Measurement specialists will store all measurements that are not raster data (i.e., a grid of regularly or irregularly sized pixels [two-dimensional] or voxels [threedimensionals]) in Microsoft (MS) Excel.

- Measurement specialists will explicitly set the data type and the significant digits of all measurements within the MS Excel spreadsheet.

- Measurement specialists will record all data pertinent to a respective set of measurement devices within a single table (e.g., all wind speed measurements will be contained within a single tab in MS Excel).

- Each measurement device within a set of measurements will contain a unique identifier for that device (e.g., anemometers 1, 2, 3, 4, et).

- Attribute values that contain classification values will have consistent values (e.g., wood construction will not contain "Wood," "WOOD," and "wood," but only one of these values). Measurement specialists can enforce the creation of consistent classification values through the use of drop-down lists.

- Measurement specialists will document all attribute values containing measurement in the international system of units (SI). If measurement specialists collect data in English units, a corresponding column adjacent to the original measurement containing the SI measurement unit will be created and populated. Measurement specialists will maintain the appropriate significant digits during the conversion. 
- All measurements collected with a temporal component or sampling rate will have an explicit attribute describing the measurement time at the appropriate sampling rate.

- All measurements collected over time will have an additional attribute describing the measurement's start time in coordinated universal time (UTC).

- Measurement specialists will synchronize all measurements collected with a temporal component to the National Institute of Standards and Technology (NIST) official US time.

- Measurement specialists will record the location of all measurement devices from an established origin.

- Each measurement device will have an X, Y, and Z measure documented in the respective attribute table. If measurement specialists document locations in English units, the measurement specialists will include additional attributes to record the location's SI equivalent. English units will be recorded with decimal units and not a combination of units (e.g., 5' 3/4" is not acceptable, and 5.75 feet is acceptable).

- Each measurement will contain a "flag" code to identify measurements determined to be in error after conducting the respective quality control regarding the desired data quality objectives.

- No measurement will contain empty values in the attribute table. If the measurement device did not record a measurement, measurement specialists would replace the attribute value with a $-99,-999$, or -9999 .

- All data tables will have an attribute describing the respective test for which measurement specialists collect the data.

- All attributes representing a particular test will follow the naming convention detailed in this study plan.

- As appropriate, each data file will adhere containing the following fields, in the following format, with additional attributes representing measurements and other information as required:

○ experiment_name: A text field describing the experiment for which the data contained in the spreadsheet applies. The names of experiments should follow the standards presented in this study plan.

o sensor_id: A text field representing a unique identifier for each sensor, shed, platform, or other measurement devices, source objects, or target objects (e.g., anemometer, thermocouple, shed, etc.).

o time: The time of the measurement in UTC formatted as [h]:mm:ss.00.

O $\mathbf{x} \_\mathbf{m}$ : The $\mathrm{X}$ coordinate in meters of the respective image or video file consistent with the coordinate system established for the experiment. This field will be a number field recorded to two decimal places.

○ $\mathbf{y}_{-} \mathbf{m}$ : The Y coordinate in meters of the respective image or video file consistent with the coordinate system established for the experiment. This field will be a number field recorded to two decimal places.

○ $\quad z_{-} \mathbf{m}$ : The $\mathrm{Z}$ coordinate in meters of the height at which data collectors recorded the image or video. This field will be a number field recorded to two decimal places.

○ $\quad \mathbf{x}_{-} \mathbf{f t}$ : The $\mathrm{X}$ coordinate in feet of the respective image or video file consistent with the coordinate system established for the experiment. This field will be a number field recorded to two decimal places. 
○ $\quad \mathbf{y}_{-} \mathbf{f t}$ : The Y coordinate in feet of the respective image or video file consistent with the coordinate system established for the experiment. This field will be a number field recorded to two decimal places.

- $\quad \mathbf{z}_{-} \mathbf{f t}$ : The $\mathrm{Z}$ coordinate in meters of the height at which data collectors recorded the image or video. This field will be a number field recorded to two decimal places.

The project will produce structured raster or gridded data of two-dimensional (2D) and threedimensional (3D) data using various file formats. The majority of this data will come from the modeling efforts using the Fire Dynamics Simulator (FDS) and will follow standards for input files and output files implemented by FDS.

The project will collect and record images and videos on the ground of the experiments. All videos and images will adhere to file naming conventions described above. Additionally, videos and images will adhere to the following standards:

- All videos and images will contain an associated Excel spreadsheet containing the following attributes:

- All the standard and required attributes detailed above under tabular data standards.

○ image_video_name: The video and image file name, adhering to the standards described above.

- notes: A short description of the video or image file.

- file_link: a link to the image or video file on the Google Drive.

\section{F.5 Structure Separation Experiment Data Flows for Measurement Specialists, Data Collectors, and Data Managers}

The SSE Phase 1 project will have the data flows shown in the diagrams below. 


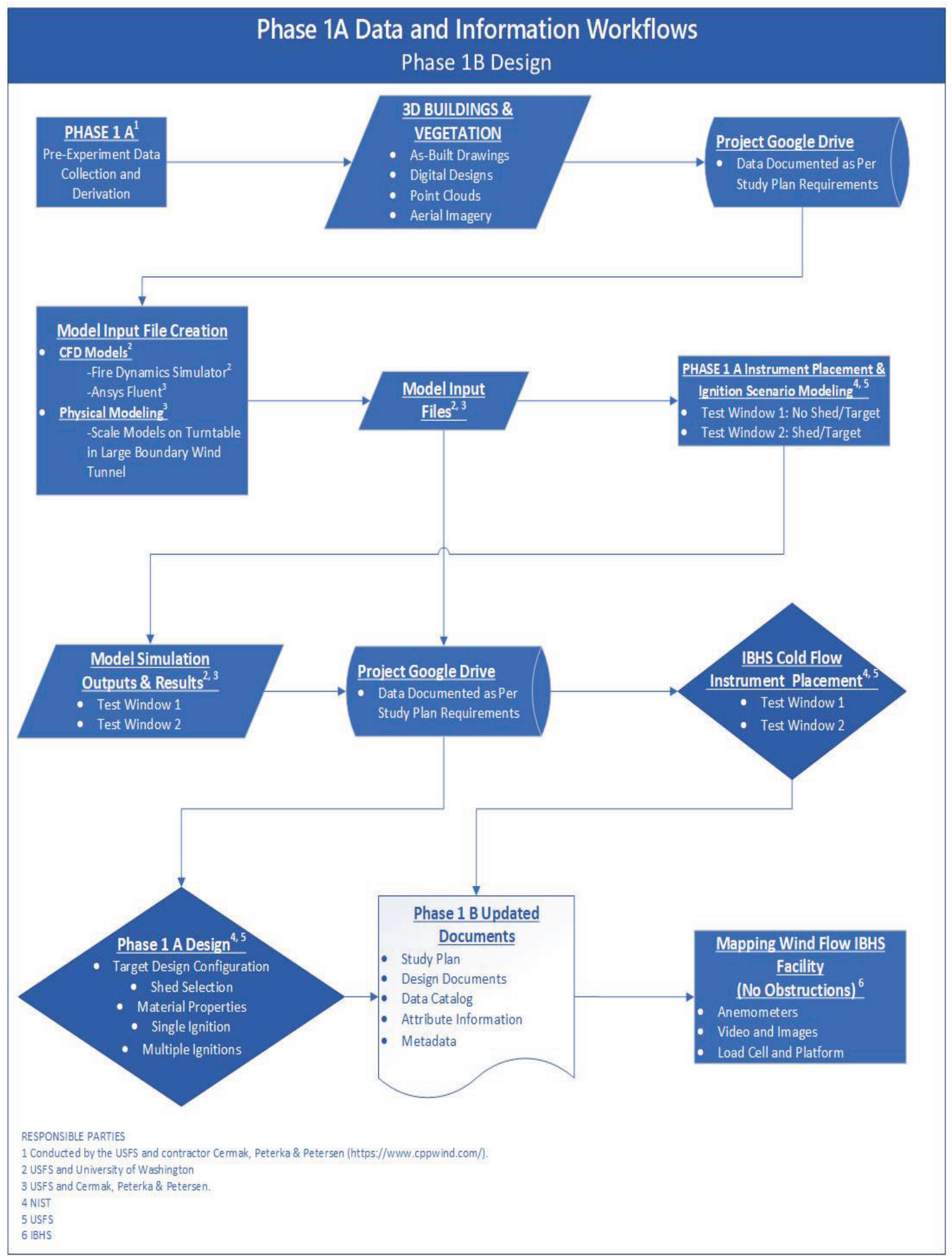

